\title{
Effects of Thermal Aging on Fracture Toughness and Charpy-Impact Strength of Stainless Steel Pipe Welds
}

Manuscript Completed: November 1995

Date Published: May 1996

Prepared by

D. J. Gavenda, W. F. Michaud, T. M. Galvin, W. F. Burke, and O. K. Chopra

Argonne National Laboratory

9700 South Cass Avenue

Argonne, IL 60439

M. E. Mayfield, NRC Project Manager

Prepared for

Office of Nuclear Regulatory Research

U.S. Nuclear Regulatory Commission

Washington, DC 20555

NRC FIN A2212 


\title{
Effects of Thermal Aging on Fracture Toughness and Charpy-Impact Strength of Stainless Steel Pipe Welds
}

\author{
by \\ D. J. Gavenda, W. F. Michaud, T. M. Galvin, \\ W. F. Burke, and O. K. Chopra
}

\begin{abstract}
The degradation of fracture toughness, tensile, and Charpy-impact properties of Type 308 stainless steel (SS) pipe welds due to thermal aging has been characterized at room temperature and $290^{\circ} \mathrm{C}$. Thermal aging of SS welds results in moderate decreases in Charpy-impact strength and fracture toughness. For the various welds in this study, upper-shelf energy decreased by $50-80 \mathrm{~J} / \mathrm{cm}^{2}$. The decrease in fracture toughness $\mathrm{J}-\mathrm{R}$ curve or $\mathrm{J}_{\mathrm{C}} \mathrm{C}$ is relatively small. Thermal aging had little or no effect on the tensile strength of the welds. Fracture properties of SS welds are controlled by the distribution and morphology of second-phase particles. Failure occurs by the formation and growth of microvoids near hard inclusions; such processes are relatively insensitive to thermal aging. The ferrite phase has little or no effect on the fracture properties of the welds. Differences in fracture resistance of the welds arise from differences in the density and size of inclusions. Mechanical-property data from the present study are consistent with results from other investigations. The existing data have been used to establish minimum expected fracture properties for SS welds.
\end{abstract}




\section{Contents}

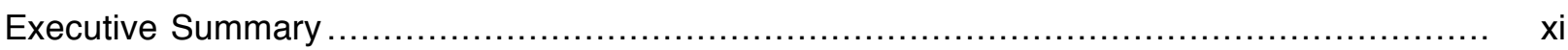

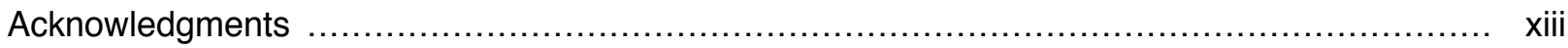

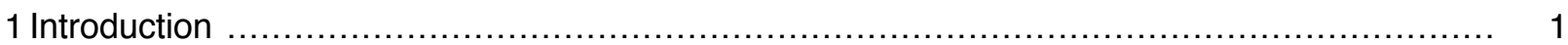

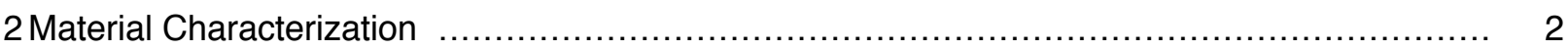

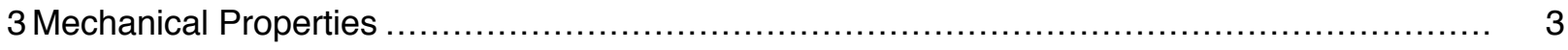

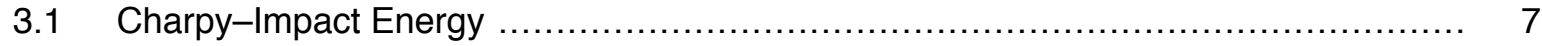

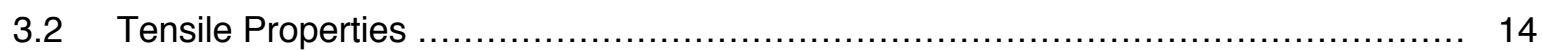

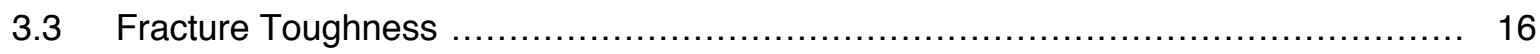

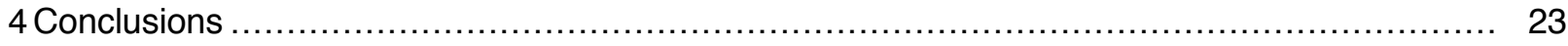

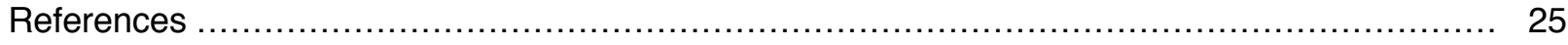

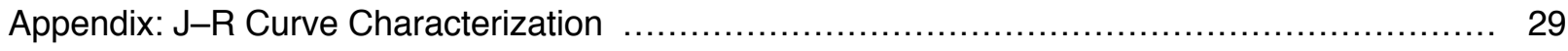

\section{Figures}

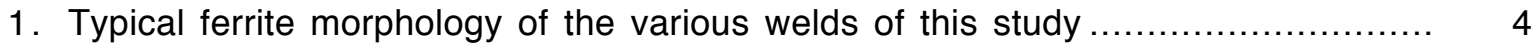

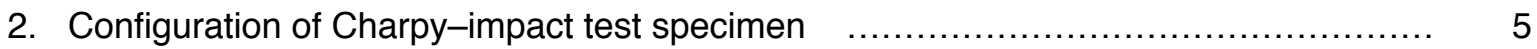

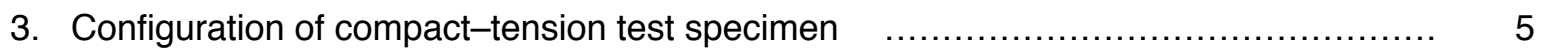

4. Orientation and location on weldments where mechanical test specimens were taken

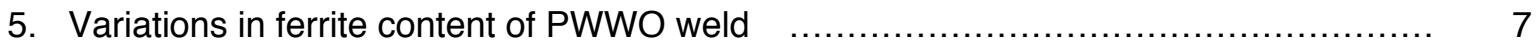

6. Effect of therm al aging on Charpy-transition curve for PWWO weld $\quad \ldots \ldots \ldots \ldots \ldots \ldots \ldots . . . . . . .9$

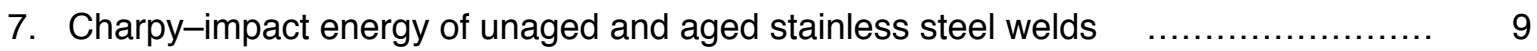

8. Photomicrographs of fracture surface of unaged and aged Charpy specimens of various welds tested at room temperature 
9. Higher-magnification photomicrographs of fracture surface of unaged and aged Charpy specimens of PWWO and PWDR welds tested at room temperature....

10. Photomicrograph of fracture surface of unaged Charpy specimen of PWWO weld tested at $-180^{\circ} \mathrm{C}$.

11. Tensile yield and ultimate stress of stainless steel welds

12. Fracture toughness $\mathrm{J}-\mathrm{R}$ curve for PWCE weld at room temperature and $290^{\circ} \mathrm{C} \quad \ldots \ldots \quad 18$

13. Fracture toughness J-R curve for PWWO weld at room temperature and $290^{\circ} \mathrm{C} \quad \ldots . \quad 19$

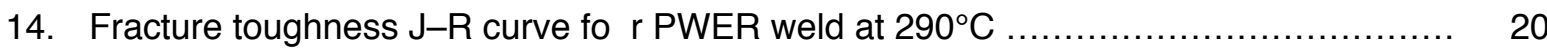

15. Fracture toughness $\mathrm{J}-\mathrm{R}$ curves for stainless steel welds at room temperature and $288-427^{\circ} \mathrm{C}$

16. Fracture toughness $\mathrm{J}-\mathrm{R}$ curves for aged stainless steel welds at room temperature and $288^{\circ} \mathrm{C}$

17. Fracture toughness $J_{I C}$ for unaged and aged stainless steel welds

18. Fracture toughness J-R curves represented by Eqs. 3 and 4 and the data for aged $\mathrm{CF}-3$ and $316 \mathrm{~L}$ welds and that in the technical basis document for ASME Code IWB-3640 analysis.

A-1. Fracture surface of unaged weld metal PWCE tested at $25^{\circ} \mathrm{C}$

A-2. Deformation J-R curve for unaged weld metal specimen PWCE-02 tested at $25^{\circ} \mathrm{C}$

A-3. Modified J-R curve for unaged weld metal specimen PWCE-02 tested at $25^{\circ} \mathrm{C}$

A-4. Fracture surface of aged weld metal PWCE tested at $25^{\circ} \mathrm{C}$

A-5. Deformation J-R curve for weld metal specimen PWCE-04 aged at $400^{\circ} \mathrm{C}$ for $10,000 \mathrm{~h}$ and tested at $25^{\circ} \mathrm{C}$.

A-6. Modified J-R curve for weld metal specimen PWCE-04 aged at $400^{\circ} \mathrm{C}$ for $10,000 \mathrm{~h}$ and tested at $25^{\circ} \mathrm{C}$

A-7. Fracture surface of unaged weld metal PWCE tested at $290^{\circ} \mathrm{C}$

A-8. Deformation J-R curve for unaged weld metal specimen PWCE-01 tested at $290^{\circ} \mathrm{C}$ 
A-9.Modified J-R curve for unaged weld metal specimen PWCE-01 tested at $290^{\circ} \mathrm{C} \ldots \ldots \ldots \quad 45$

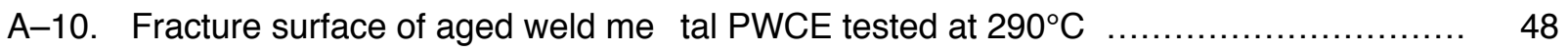

A-11. Deformation J-R curve for weld metal specimen PWCE-03 aged at $400^{\circ} \mathrm{C}$ for

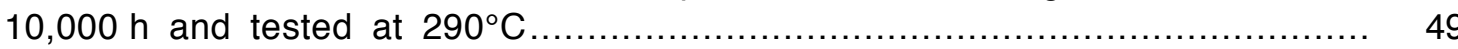

A-12. Modified J-R curve for weld metal specimen PWCE-03 aged at $400^{\circ} \mathrm{C}$ for

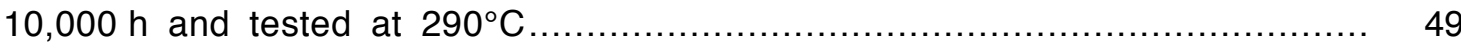

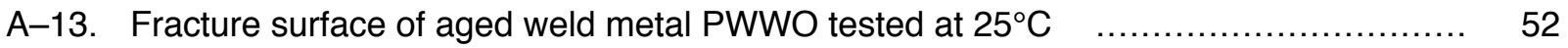

A-14. Deformation J-R curve for weld metal specimen PWWO-03 aged at $400^{\circ} \mathrm{C}$ for $7,700 \mathrm{~h}$ and tested at $25^{\circ} \mathrm{C}$

A-15. Modified J-R curve for weld metal specimen PWWO-03 aged at $400^{\circ} \mathrm{C}$ for $7,700 \mathrm{~h}$ and tested at $25^{\circ} \mathrm{C}$

A-16. Fracture surface of unaged weld metal PWWO tested at $290^{\circ} \mathrm{C}$

A-17. Deformation $\mathrm{J}-\mathrm{R}$ curve for unaged weld metal specimen PWWO-01 tested at $290^{\circ} \mathrm{C}$

A-18. Modified J-R curve for unaged weld metal specimen PWWO-01 tested at $290^{\circ} \mathrm{C}$

A-19. Fracture surface of aged weld metal PWWO tested at $290^{\circ} \mathrm{C}$

A-20. Deformation J-R curve for weld metal specimen PWWO-04 aged at $400^{\circ} \mathrm{C}$ for $7,700 \mathrm{~h}$ and tested at $290^{\circ} \mathrm{C}$

A-21. Modified J-R curve for weld metal specimen PWWO-04 aged at $400^{\circ} \mathrm{C}$ for $7,700 \mathrm{~h}$ and tested at $290^{\circ} \mathrm{C}$

A-22. Fracture surface of aged weld metal PWWO tested at $290^{\circ} \mathrm{C}$

A-23. Deformation J-R curve for weld metal specimen PWWO-02 aged at $400^{\circ} \mathrm{C}$ for $7,700 \mathrm{~h}$ and tested at $290^{\circ} \mathrm{C}$

A-24. Modified J-R curve for weld metal specimen PWWO-02 aged at $400^{\circ} \mathrm{C}$ for $7,700 \mathrm{~h}$ and tested at $290^{\circ} \mathrm{C}$.

A-25. Fracture surface of aged weld metal PWER tested at $290^{\circ} \mathrm{C}$

A-26. Deformation J-R curve for weld metal specimen PWER-01 aged at $400^{\circ} \mathrm{C}$ for $10,000 \mathrm{~h}$ and tested at $290^{\circ} \mathrm{C}$ 
A-27. Modified J-R curve for weld metal specimen PWER-01 aged at $400^{\circ} \mathrm{C}$ for $10,000 \mathrm{~h}$ and tested at $290^{\circ} \mathrm{C}$

\section{Tables}

1. Composition and ferrite content of austenitic stainless steel welds .................. 2

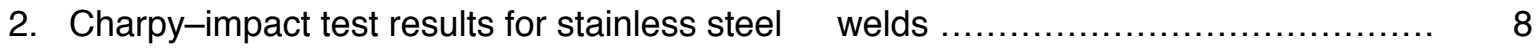

3. Summary of mechanical-property data for austenitic stainless steel welds $\quad \ldots \ldots \ldots \ldots . . .10$

4. Tensile yield and ultimate stress of various stainless steel welds, estimated

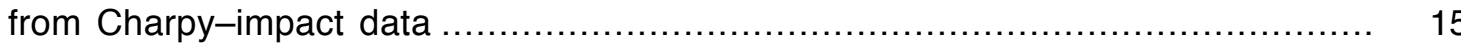

5. Fracture toughness test results for unaged and aged austenitic stainless steel weldments.

A-1. Test data for specimen PWCE-02

A-2. Deformation $\mathrm{J} I \mathrm{I}$ and J-R curve results for specimen PWCE-02 …................. 35

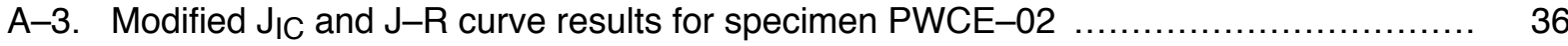

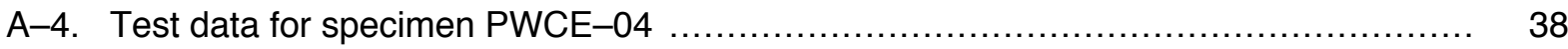

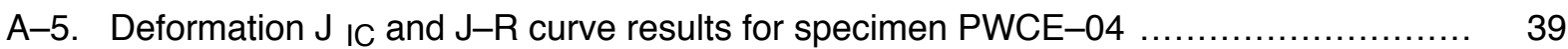

A-6. Modified $\mathrm{J}_{\mathrm{I}} \mathrm{C}$ and $\mathrm{J}-\mathrm{R}$ curve results for specimen PWCE-04 .......................... 40

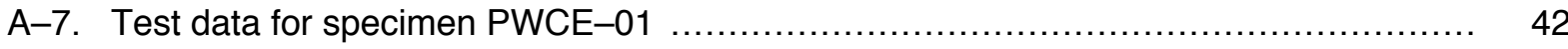

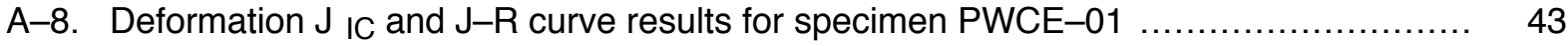

A-9. Modified $J_{I C}$ and J-R curve results for specimen PWCE-01 ......................... 44

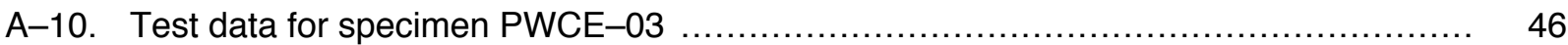

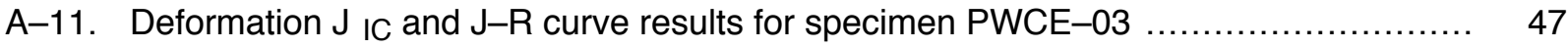

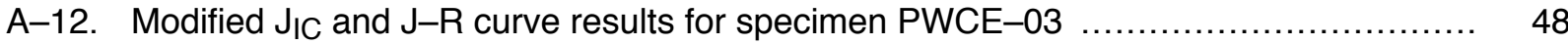

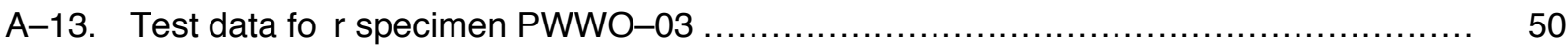

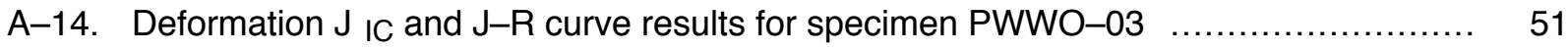

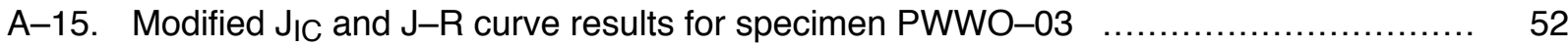


A-16. Test data for specimen PWWO-01

A-17. Deformation J IC and J-R curve results for specimen PWWO-01 $\ldots \ldots \ldots \ldots \ldots \ldots \ldots \ldots \ldots$

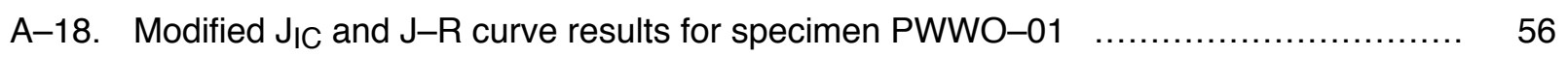

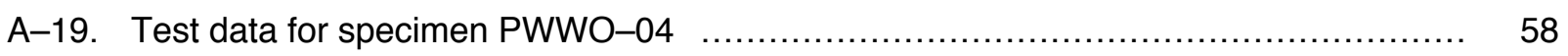

A-20. Deformation J IC and J-R curve results for specimen PWWO-04 $\ldots \ldots \ldots \ldots \ldots \ldots \ldots \ldots \ldots$

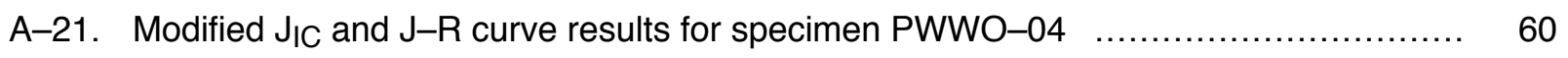

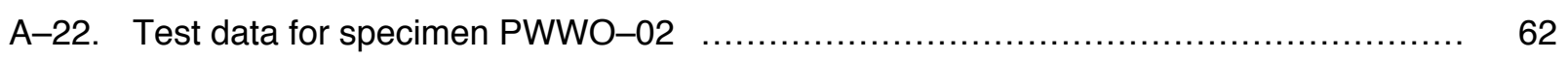

A-23. Deformation J IC and J-R curve results for specimen PWWO-02 $\ldots \ldots \ldots \ldots \ldots \ldots \ldots \ldots$

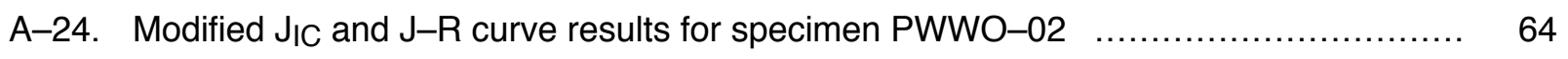

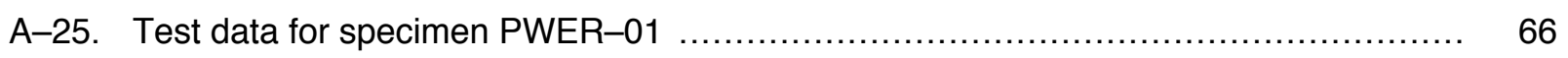

A-26. Deformation J IC and J-R curve results for specimen PWER-01 $\ldots \ldots \ldots \ldots \ldots \ldots \ldots \ldots . \ldots 7$

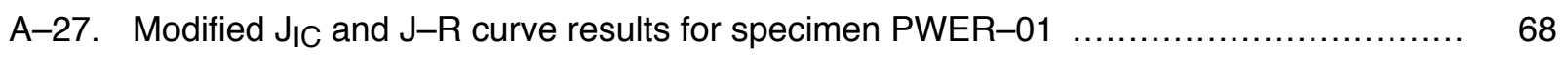




\section{Executive Summary}

Stainless steels (SSs) are used extensively in light water reactor (LWR) systems because of their excellent ductility, high notch toughness, corrosion resistance, and good formability. Although these steels are completely austenitic in the wrought condition, welded and cast SSs have a duplex structure consisting of austenite and ferrite phases. The ferrite phase provides additional benefits, e.g., it increases tensile strength and improves the resistance to stress corrosion cracking. However, the duplex steels are susceptible to thermal embrittlement after extended service at reactor operating temperatures, i.e., typically $282^{\circ} \mathrm{C}\left(540^{\circ} \mathrm{F}\right)$ for boiling water reactors, $288-327^{\circ} \mathrm{C}\left(550-621^{\circ} \mathrm{F}\right)$ for pressurized water reactor (PWR) primary coolant piping, and $343^{\circ} \mathrm{C}\left(650^{\circ} \mathrm{F}\right)$ for PWR pressurizers.

It is well established that thermal embrittlement of cast duplex SSs at reactor temperatures increases hardness and tensile strength; decreases ductility, impact strength, and fracture toughness; and shifts the Charpy transition curve to higher temperatures. Thermal embrittlement is caused primarily by formation of the $\mathrm{Cr}$-rich $\alpha^{\prime}$ phase in the ferrite and, to some extent, by precipitation and growth of carbides at phase boundaries. It results in brittle fracture associated with either cleavage of the ferrite or separation of the ferrite/austenite phase boundary. Predominantly brittle failure occurs when either the ferrite phase is continuous (e.g., in material with a large ferrite content) or the ferrite/austenite phase boundary provides an easy path for crack propagation (e.g., in materials with high $\mathrm{C}$ content). The amount, size, and distribution of the ferrite phase in the duplex structure, and the presence of phase-boundary carbides are important parameters in controlling the degree or extent of thermal embrittlement.

A procedure and correlations have been developed for estimating fracture toughness, tensile, and Charpy-impact properties of cast SS components during service from known material information. Although SS welds have a duplex structure and their chemical compositions are similar to those of cast SSs, the estimation scheme is not applicable to SS welds. The degradation of fracture toughness, tensile, and Charpy-impact properties of Type 308 pipe welds due to thermal aging has been characterized in this report. The welds were aged for 7,000$10,000 \mathrm{~h}$ at $400^{\circ} \mathrm{C}$ to simulate saturation conditions, i.e., lowest impact energy that would be achieved by the material after long-term aging. The results have been compared with fractureproperty data from other studies.

Thermal aging of the SS welds resulted in moderate decreases in Charpy-impact strength and fracture toughness at both room temperature and $290^{\circ} \mathrm{C}$. For the various welds, USE decreased by $50-80 \mathrm{~J} / \mathrm{cm}^{2}(30-47 \mathrm{ft} \cdot \mathrm{lb}$.$) . The decrease in the fracture toughness \mathrm{J}-\mathrm{R}$ curve or $J_{I C}$ is relatively small. Metallographic examination of the specimens indicates that failure occurs by the formation and growth of microvoids near hard inclusions. Differences in the fracture resistance of the welds arises from differences in the density and size of inclusions. In this study, the effect of thermal aging on fracture properties is minimal because of the relatively low ferrite content (4-6\% ferrite) and thin vermicular ferrite morphology in the welds.

The Charpy-impact, tensile, and fracture toughness results from this study have been compared with available data on SMAWs, SAWs, and GTAWs prepared with Types 308 or 316 SS filler metal. The data are consistent with results from other investigations. The fracture properties of SS welds are insensitive to filler metal. The welding process has a significant ef- 
fect. In general, GTAWs exhibit higher fracture resistance than SMAWs or SAWs, and there is no difference between SAW and SMAW J-R curves. The Charpy-impact energy of some welds may be as low as $40 \mathrm{~J}$.

The results indicate that the decrease in impact strength due to aging depends on the ferrite content and initial impact strength of the weld. Welds with relatively high strength show a large decrease whereas those with poor strength show minimal change. In SS welds with poor strength, failure occurs by the formation and growth of microvoids. Such processes are relatively insensitive to thermal aging. The existing data indicate that at reactor temperatures, the fracture toughness $J_{I C}$ of thermally aged welds can be as low as $40 \mathrm{~kJ} / \mathrm{m}^{2}$. A conservative estimate of $\mathrm{J}-\mathrm{R}$ curve for aged SS welds may be given by $\mathrm{J}=40+83.5 \Delta \mathrm{a}^{0.643}$. 


\section{Acknowledgments}

This work was supported by the Office of the Nuclear Regulatory Research in the U.S. Nuclear Regulatory Commission (NRC), under FIN A2212, Program Manager: Michael McNeil. 


\section{Introduction}

Stainless steels (SSs) are used extensively in light water reactor (LWR) systems because of their excellent ductility, high notch toughness, corrosion resistance, and good formability. Although these steels are completely austenitic in the wrought condition, welded and cast SSs have a duplex structure consisting of austenite and ferrite phases. The ferrite phase provides additional benefits, e.g., it increases tensile strength and improves resistance to stress corrosion cracking. However, duplex steels are susceptible to thermal embrittlement after extended service at reactor operating temperatures, i.e., typically $282^{\circ} \mathrm{C}\left(540^{\circ} \mathrm{F}\right)$ for boiling water reactors, $288-327^{\circ} \mathrm{C}\left(550-621^{\circ} \mathrm{F}\right)$ for pressurized water reactor (PWR) primary coolant piping, and $343^{\circ} \mathrm{C}\left(650^{\circ} \mathrm{F}\right)$ for PWR pressurizers.

It is well established $1-7$ that thermal aging of cast SSs at $250-350^{\circ} \mathrm{C}\left(482-662^{\circ} \mathrm{F}\right)$ increases hardness and tensile strength; decreases ductility, impact strength, and fracture toughness; and shifts the Charpy transition curve to higher temperatures. Aging of cast SSs at temperatures $<500^{\circ} \mathrm{C}\left(<932^{\circ} \mathrm{F}\right)$ leads to precipitation of additional phases in the ferrite, e.g., formation of a $\mathrm{Cr}$-rich $\alpha^{\prime}$ phase by spinodal decomposition; nucleation and growth of $\alpha^{\prime}$; precipitation of a $\mathrm{Ni}-$ and $\mathrm{Si}$-rich $\mathrm{G}$ phase, $\mathrm{M}_{23} \mathrm{C}_{6}$, and $\gamma_{2}$ (austenite); and additional precipitation and/or growth of existing carbides at ferrite/austenite phase boundaries. ${ }^{8-12}$ Thermal embrittlement is caused primarily by formation of the $\mathrm{Cr}$-rich $\alpha^{\prime}$ phase in the ferrite and, to some extent, by precipitation and growth of carbides at phase boundaries. Thermal embrittlement of cast SSs results in brittle fracture associated with either cleavage of the ferrite or separation of the ferrite/austenite phase boundary. Predominantly brittle failure occurs when either the ferrite phase is continuous (e.g., in cast material with a large ferrite content) or the ferrite/austenite phase boundary provides an easy path for crack propagation (e.g., in high-C grades of cast steel with large phase-boundary carbides). The amount, size, and distribution of the ferrite phase in the duplex structure, and the presence of phase-boundary carbides are important parameters in controlling the degree or extent of thermal embrittlement. In general, the low-C CF-3 steels are the most resistant to thermal embrittlement, and the Mo-bearing, high-C CF$8 \mathrm{M}$ steels are the least resistant. The extent of thermal embrittlement increases with increased ferrite content.

A procedure and correlations have been developed at Argonne National Laboratory (ANL) for estimating fracture toughness, tensile, and Charpy-impact properties of cast SS components during service from known material information. ${ }^{13,14}$ The ANL estimation scheme is applicable to compositions within the ASTM Specifications A 351 for Grades CF-3, CF-3A, CF-8, CF-8A, and CF-8M. A correlation for Charpy-impact energy at saturation, i.e., the mini mum impact energy that would be achieved for the material after long-term aging, is given in terms of chemical composition. Change in impact energy as a function of time and temperature of service is estimated from saturation impact energy and from the correlations that describe the kinetics of embrittlement, which are also given in terms of chemical composition. The fracture toughness $\mathrm{J}-\mathrm{R}$ curve for the material is then obtained from the correlation between the fracture toughness parameters and the Charpy-impact energy. Tensile yield and flow stresses, and Ramberg/Osgood parameters are estimated from the flow stress of the unaged material and the kinetics of embrittlement. ${ }^{3}$

Although SS welds have a duplex structure and their chemical compositions are similar to those of cast SSs, the ANL correlations are not applicable to these welds. The ANL correlations 
account for mechanical-property degradation of typical heats of cast SS. They do not consider the effects of compositional or structural differences that may arise from differences in processing or heat treatment of the steels. Type 308 SS welds generally contain $5-15 \%$ ferrite but their mechanical properties typically differ from those of cast SSs. For a given ferrite content, the tensile strength of SS welds is higher and fracture toughness is lower than that of cast SSs. Experimental data 15 indicate that cast SSs with poor fracture toughness are relatively insensitive to thermal aging, i.e., fracture toughness of the material would not change significantly during service. In these steels, failure is controlled by void formation near inclusions or other flaws in the material, i.e., by processes that are not sensitive to thermal aging. These results suggest that SS welds with poor fracture toughness, e.g., shielded metal arc welds (SMAWs) or submerged arc welds (SAWs), should be relatively insensitive to thermal aging.

Degradation of fracture toughness and Charpy-impact energy of several SS pipe welds has been characterized in this report. The welds were aged for $7,000-10,000 \mathrm{~h}$ at $400^{\circ} \mathrm{C}$ to simulate saturation conditions, i.e., the lowest impact energy that would be achieved by the material after long-term aging. The results are compared with data from other studies.

\section{Material Characterization}

Five pipe weldments were procured for the study. The composition and ferrite content of the welds are given in Table 1. The ferrite content was measured with a ferrite scope and calculated from the chemical composition in terms of Hull's equivalent factors. ${ }^{16}$ Fabrication and procurement history of the weldments is as follows:

PWWO: 12-in. Type 304 Schedule 100 pipe mockup weldment with overlays was supplied by Georgia Power and NUTECH. ${ }^{17}$ The weld was fabricated with Type 308L filler metal and conventional butt welding procedures. On one side of the weld the prep geometry of the weld was long and smooth, i.e., typical of that used in the Hatch-1 reactor. On the other side, the prep geometry was short, typical of that used in the Hatch-2 reactor. The overlay was similar to that applied to the recirculation piping in the Hatch-2 reactor.

PWCE: 28-in., Type 304/308 pipe weldment was obtained from the Boston Edison Power Co.

Table 1. Composition and ferrite content of austenitic stainless steel welds

\begin{tabular}{lccccccccccccc}
\hline \multirow{2}{*}{$\begin{array}{l}\text { Material } \\
\text { ID }\end{array}$} & \multicolumn{1}{c}{$\mathrm{C}$} & $\mathrm{N}$ & $\mathrm{Si}$ & $\mathrm{Mn}$ & $\mathrm{P}$ & $\mathrm{S}$ & $\mathrm{Ni}$ & $\mathrm{Cr}$ & $\mathrm{Mo}$ & $\mathrm{Cu}$ & & \multicolumn{1}{c}{ Calc. } & Meas. \\
\hline PWWO & 0.030 & 0.072 & 0.44 & 2.12 & 0.018 & 0.018 & 10.72 & 20.35 & 0.27 & 0.20 & 4.1 & 6.8 \\
PWCE & 0.050 & 0.060 & 0.44 & 1.79 & 0.003 & 0.002 & 9.54 & 20.22 & 0.05 & 0.04 & 5.4 & 6.1 \\
PWER & 0.020 & 0.074 & 0.36 & 1.78 & 0.018 & 0.009 & 10.29 & 20.12 & 0.19 & 0.12 & 4.8 & 5.2 \\
PWDR & 0.080 & - & 0.75 & 1.00 & 0.022 & 0.010 & 9.74 & 20.72 & 0.08 & 0.08 & 5.9 & - \\
PWMS & 0.021 & - & 0.40 & 1.61 & 0.025 & 0.006 & 9.56 & 19.80 & 0.19 & 0.11 & 8.3 & - \\
\hline
\end{tabular}

a PWWO: 12-in. schedule 100 pipe mockup weldment with overlays supplied by Georgia Power and NUTECH.

PWCE: 28-in.-diameter Type 304 stainless steel pipe weldment obtained from Boston Edison.

PWER: 20-in.-diameter Type 304 stainless steel pipe weldment prepared for EPRI at Southwest Fabricating.

PWDR: 10-in.-diameter Type 304 stainless steel weldment after service in Dresden reactor.

PWMS: 28-in.-diameter pipe weldment treated by Mechanical Stress Improvement Process (MSIP).

b Calculated from the composition with Hull's equivalent factor.

Measured by Ferrite Scope, Auto Test FE, Probe Type FSP-1. 
PWER: 20-in., Type 304/308 pipe weldment was supplied by the Electric Power Research Institute (EPRI). It was prepared at Southwest Fabricating by the heat sink welding (HSW) technique. ${ }^{18}$

PWDR: 10-in., Type 304 SS pipe weldment was obtained from the emergency core-spray system of the Dresden-2 reactor. It was prepared by shielded metal arc welding with coated electrodes; the root pass was made by gas tungsten arc welding. The insert and filler metals were Type ER308. The pipe had been in service for $\approx 4.5 \mathrm{y}$. Water temperature in the core spray line is $204-260^{\circ} \mathrm{C}$ during normal operation. 19

PWMS: 28-in., seamless Type 304 SS pipe weldment was treated by the Mechanical Stress Improvement Process (MSIP). 20 The filler metal was Type ER308L. The MSIP treatment is intended to produce a more favorable state of residual stress on the inner surface of the pipe welds, particularly near heat-affected zones. The weld undergoes monotonic compressive loading that is produced by a split-ring-like tool mounted on the pipe. The favorable residual stresses are induced by plastic compression of the weld.

Although the welding process is not specified for all of the weldments, the welds of largediameter pipes are typically prepared by shielded metal arc welding. All of the welds consisted of a duplex austenite and ferrite structure; the ferrite phase was at the core of the dendritic branches in the weld. Typical microstructures of the welds are shown in Fig. 1. All of the welds exhibit a vermicular ferrite morphology. The ferrite content of the welds is relatively low (in the range of $4-6 \%$ ).

\section{Mechanical Properties}

Charpy-impact tests were conducted on standard V-notch specimens (Fig. 2) according to American Society for Testing and Materials (ASTM) Specification E 23. A Dynatup Model 8000A drop-weight impact machine with an instrumented tup and data readout system was used for the Charpy-impact tests. Load- and energy-time data were obtained from an instrumented tup and recorded on a dual-beam storage oscilloscope. The load-time traces from each test were digitized and stored on a floppy disk for analysis. Total energy was computed from the loadtime trace; the value was corrected for the effects of tup velocity.

The instrumented tup and data readout instrumentation were calibrated by fracturing standard V-notch specimens fabricated from 6061-T6 Al and 4340 steel with a hardness of Rockwell $R_{C}$ 54. Accuracy of the impact-test machine was also checked with Standard Reference Materials 2092 and 2096 obtained from the National Institute of Standards and Technology. Tests on the reference materials were performed in accordance with the testing procedures of Section 11 of ASTM E23. The specimens for high-temperature tests were heated by resistance heating. Pneumatic clamps were used to make electrical connections and hold the specimens in position on the anvils. The temperature was monitored and controlled by a thermocouple attached to the specimen. Specimens for the low-temperature tests were cooled in either a refrigerated bath or liquid $\mathrm{N}$.

The fracture toughness $\mathrm{J}-\mathrm{R}$ curve tests were conducted according to ASTM Specification E 1152-87. Compact-tension specimens (Fig. 3), $25.4 \mathrm{~mm}$ thick, were used for the tests. The experimental procedure and data for the fracture toughness tests are given in the Appendix. 


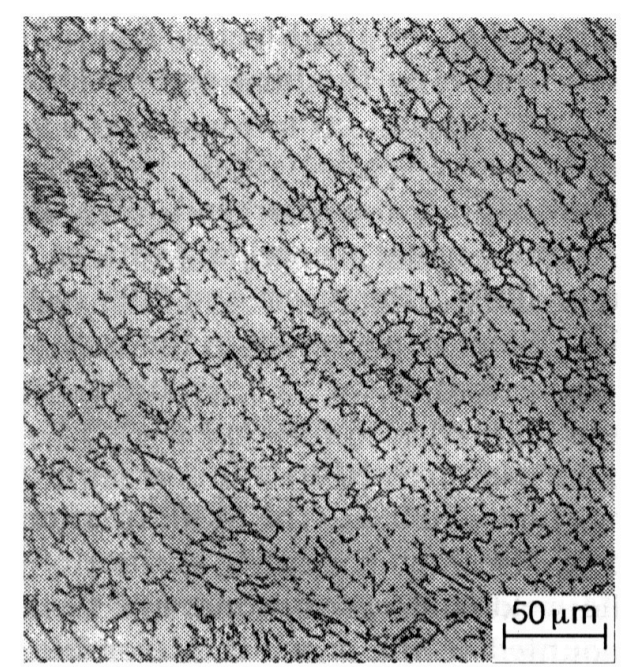

(PWWO)
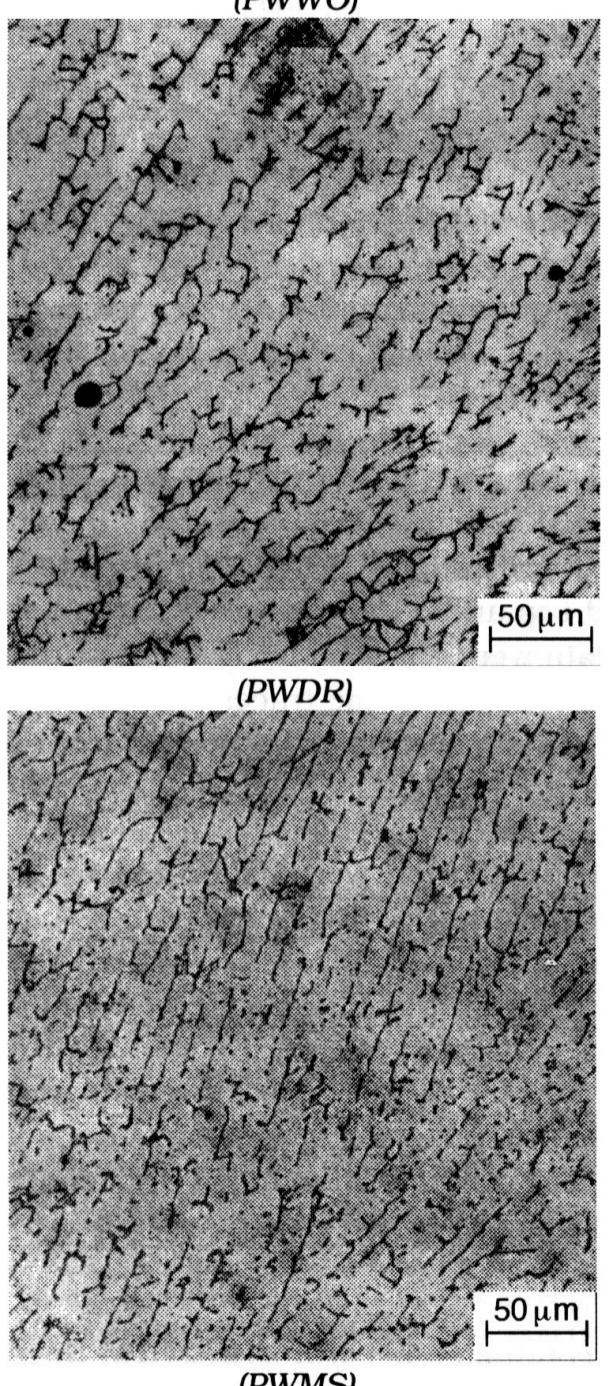

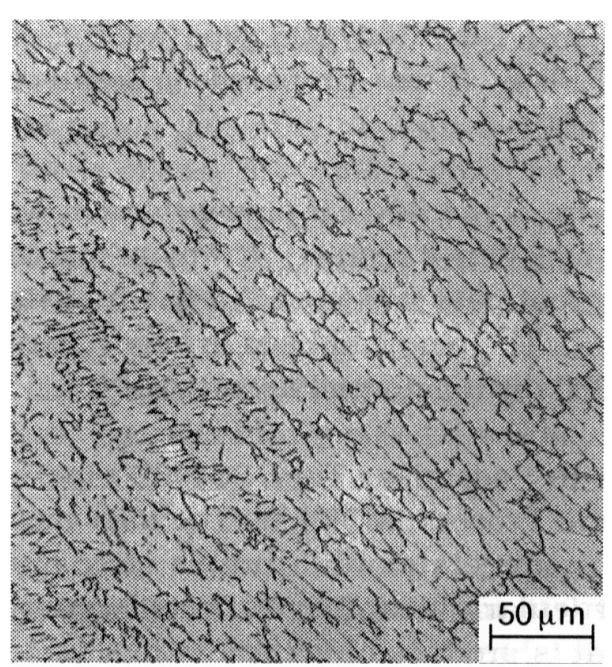

(PWCE)

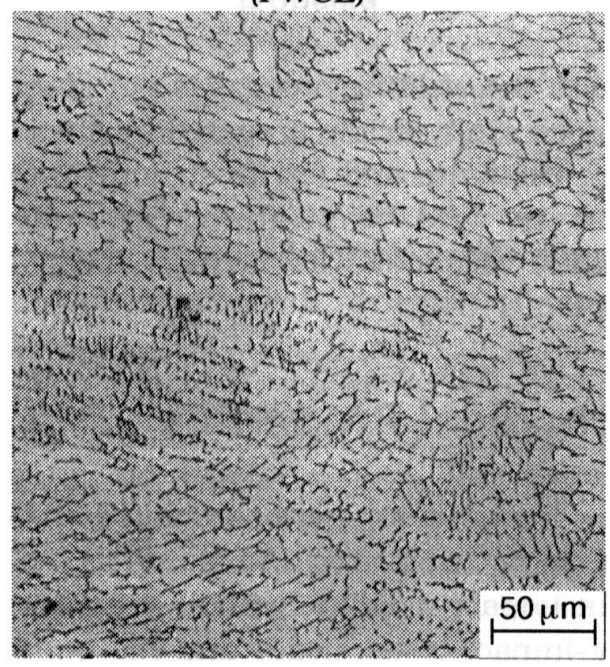

(PWER)

Figure 1. Typical ferrite morphology of the various welds of this study 

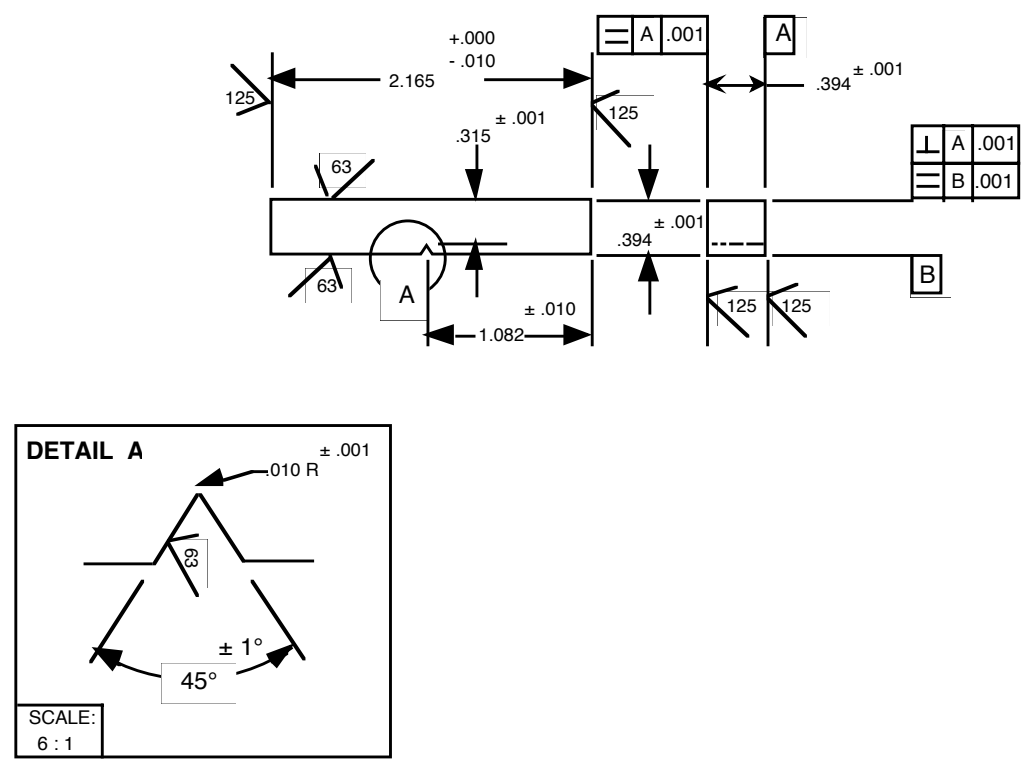

Figure 2. Configuration of Charpy-impact test specimen: units of measure are inches

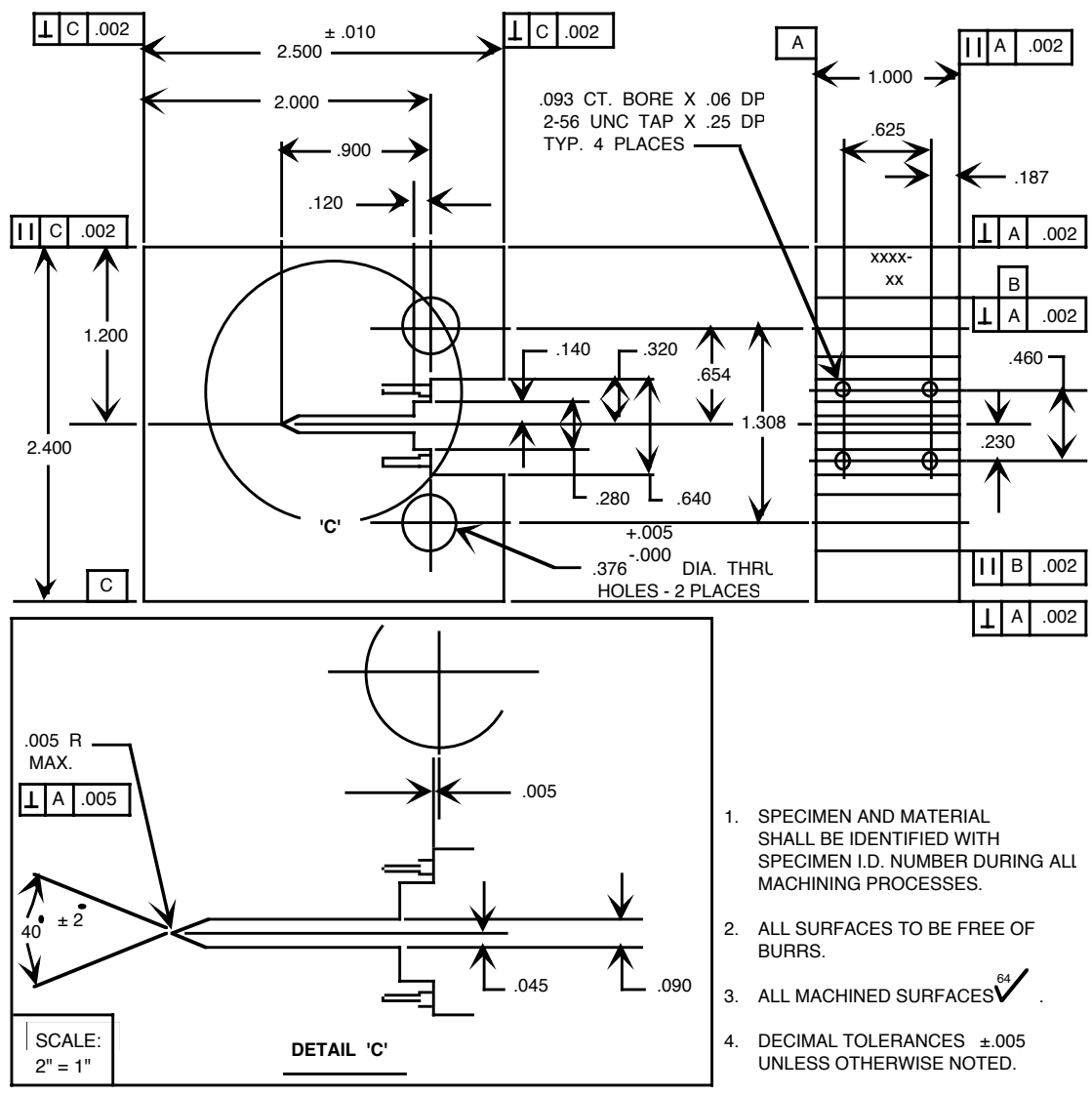

Figure 3. Configuration of compact-tension test specimen: units of measure are inches 
The orientation and location on the weldment where the Charpy-impact and fracture toughness test specimens were taken are shown in Fig. 4. In all cases, the fracture plane is in the center of the weld. The variation in ferrite content in the center of all of the welds was minimal; the variation in the PWWO weld is shown in Fig. 5. Some of the materials were aged in the laboratory for $8,000-10,000 \mathrm{~h}$ at $400^{\circ} \mathrm{C}\left(752^{\circ} \mathrm{F}\right)$ to simulate the saturation condition, i.e., the condition when the lowest impact strength is achieved by the material after long-term service at reactor temperatures.

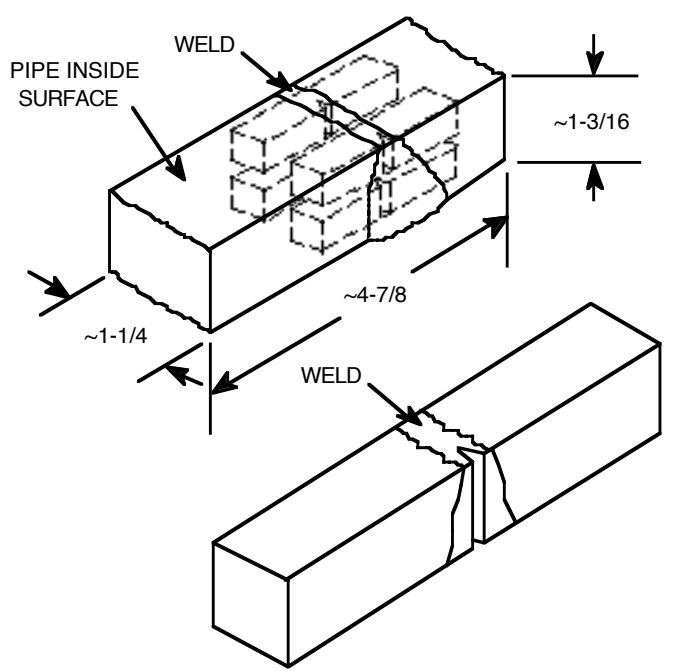

(a)

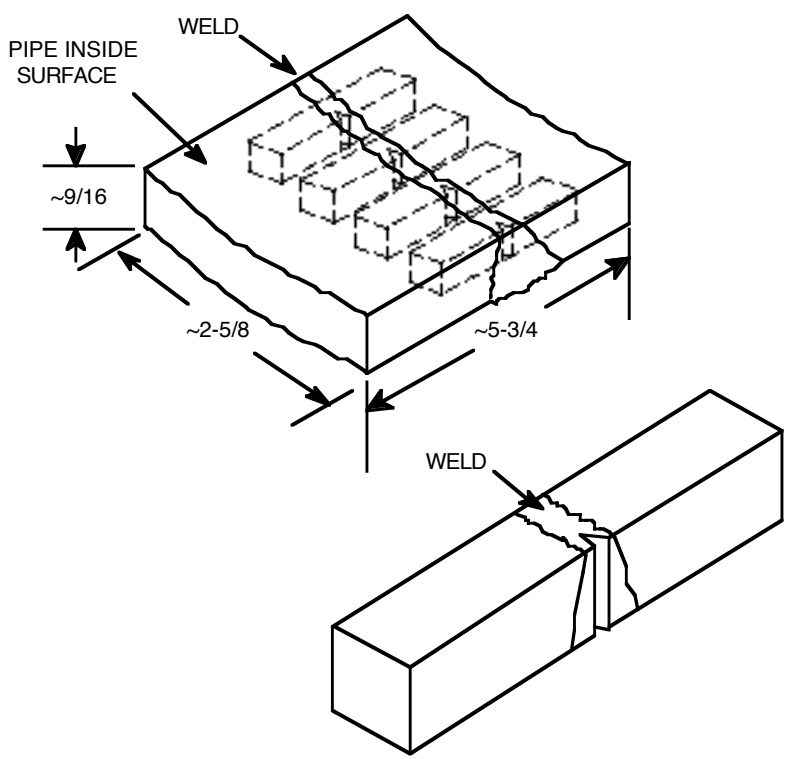

(b)

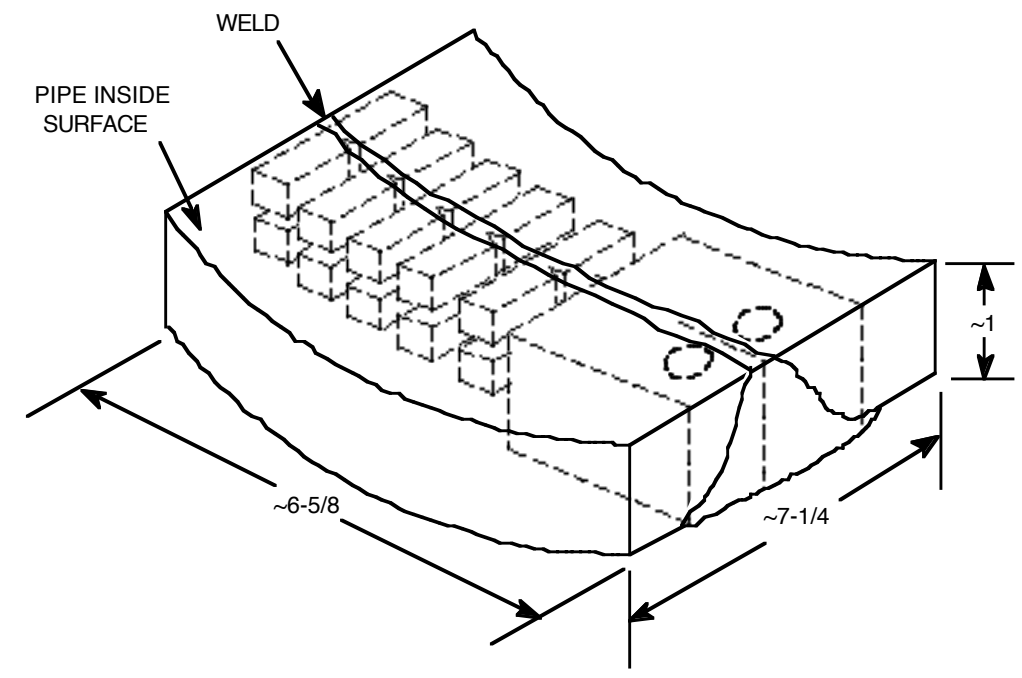

(c)

Figure 4. Orientation and location on weldments where mechanical test specimens were taken: (a) and (c) $\geq 1$ in.-thick pipe sections and (b) $<1$ in.-thick pipe sections 


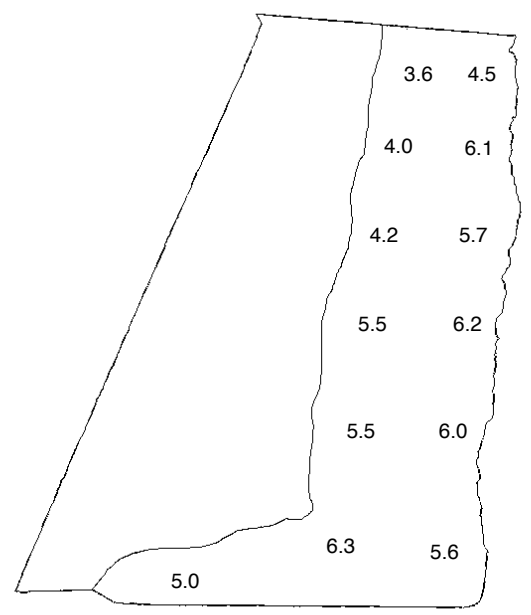

Figure 5. Variations in ferrite content of PWWO weld

\subsection{Charpy-Impact Energy}

Charpy impact data for the PWCE, PWWO, PWDR, and PWMS welds are given in Table 2. A complete Charpy transition curve was obtained only for the PWWO weld; other welds were tested at room temperature and $290^{\circ} \mathrm{C}$. Transition curves for the unaged and aged PWWO weld are shown in Fig. 6. The Charpy data were fitted with a hyperbolic tangent function of the form

$$
\mathrm{C}_{\mathrm{V}}=\mathrm{K}_{\mathrm{o}}+\mathrm{B}\left[1+\tanh \left(\frac{\mathrm{T}-\mathrm{C}}{\mathrm{D}}\right)\right]
$$

where $\mathrm{K}_{\mathrm{o}}$ is the lower-shelf energy, $\mathrm{T}$ is the test temperature in ${ }^{\circ} \mathrm{C}, \mathrm{B}$ is half the distance between the upper- and lower-shelf energy, $C$ is the mid-shelf Charpy transition temperature (CTT) in ${ }^{\circ} \mathrm{C}$, and $\mathrm{D}$ is the half width of the transition region. The results indicate that thermal aging increased the mid-shelf CTT by $47^{\circ} \mathrm{C}$, i.e., from $-105^{\circ} \mathrm{C}$ to $-58^{\circ} \mathrm{C}$, and decreased uppershelf energy (USE) by $50 \mathrm{~J} / \mathrm{cm}^{2} \quad(30 \mathrm{ft} \cdot \mathrm{lb}$.$) .$

The Charpy-impact data for aged materials represent the saturation condition, i.e., the condition when the lowest impact strength is achieved by the material after long-term service at reactor temperatures. The results indicate that thermal aging results in moderate decreases in impact energy at both room temperature and $290^{\circ} \mathrm{C}$. For the various welds, USE decreased by $50-80 \mathrm{~J} / \mathrm{cm}^{2}$ (30-47 ft.lb); from 187 to $137 \mathrm{~J} / \mathrm{cm}^{2}$ (110 to $\left.81 \mathrm{ft} \cdot \mathrm{lb}\right)$ for PWWO, from 353 to $271 \mathrm{~J} / \mathrm{cm}^{2}$ (208 to $160 \mathrm{ft} \cdot \mathrm{lb}$ ) for PWCE, and from 169 to $98 \mathrm{~J} / \mathrm{cm}^{2}$ (100 to $58 \mathrm{ft} \cdot \mathrm{lb}$ ) for PWDR. Similar decreases were observed at room temperature. Even in the fully embrittled condition, all of the welds exhibit adequate impact strength, e.g., $>90 \mathrm{~J} / \mathrm{cm}^{2}$ (53 ft.lb) at $290^{\circ} \mathrm{C}$ and $>75 \mathrm{~J} / \mathrm{cm}^{2}(44 \mathrm{ft} \cdot \mathrm{lb})$ at room temperature.

The results are consistent with the data from other investigations. Mechanical-property data on Charpy-impact, tensile, and fracture toughness properties of SMAWs, SAWs, and gas tungsten arc welds (GTAWs) prepared from Types 308 or 316 filler metal are compiled in Table 3.21-38 The Charpy-impact data for unaged and aged welds are shown in Fig. 7. The results for unaged welds show large variation; impact energy of some welds may be as low as 
Table 2. Charpy-impact test results for stainless steel welds

\begin{tabular}{|c|c|c|c|c|c|c|c|}
\hline $\begin{array}{c}\text { Test } \\
\text { Number } \\
\end{array}$ & $\begin{array}{c}\text { Specimen } \\
\text { ID }\end{array}$ & $\begin{array}{l}\text { Aging } \\
\text { Temp. } \\
\left({ }^{\circ} \mathrm{C}\right)\end{array}$ & $\begin{array}{l}\text { Aging } \\
\text { Time } \\
(\mathrm{h}) \\
\end{array}$ & $\begin{array}{l}\text { Test } \\
\text { Temp. } \\
\left({ }^{\circ} \mathrm{C}\right) \\
\end{array}$ & $\begin{array}{c}\text { Impact } \\
\text { Energy } \\
\left(\mathrm{J} / \mathrm{cm}^{2}\right) \\
\end{array}$ & $\begin{array}{l}\text { Yield Load } \\
(\mathrm{kN})\end{array}$ & $\begin{array}{c}\text { Maximum } \\
\text { Load } \\
(\mathrm{kN}) \\
\end{array}$ \\
\hline CS-2878 & PWWO-05 & - & - & -180 & 59.2 & 17.615 & 23.493 \\
\hline CS-2880 & PWWO-06 & - & - & -100 & 100.8 & 14.598 & 19.607 \\
\hline CS-2879 & PWWO-07 & - & - & -50 & 125.4 & 16.121 & 21.335 \\
\hline CS-2863 & PWWO-08 & - & - & 25 & 175.1 & 12.928 & 17.244 \\
\hline CS-2864 & PWWO-09 & - & - & 25 & 162.8 & 14.539 & 19.588 \\
\hline CS-2875 & PWWO-10 & - & - & 75 & 212.2 & 11.512 & 16.092 \\
\hline CS-2876 & PWWO-11 & - & - & 150 & 186.4 & 12.284 & 16.053 \\
\hline CS-2871 & PWWO-12 & - & - & 290 & 189.7 & 8.622 & 12.108 \\
\hline CS-2872 & PWWO-13 & - & - & 290 & 183.4 & 10.145 & 13.866 \\
\hline WIN-2882 & PWWO-14 & 400 & 7,700 & -197 & 9.8 & 13.836 & 13.836 \\
\hline WIN-2883 & PWWO-15 & 400 & 7,700 & -180 & 9.5 & 14.285 & 14.285 \\
\hline WIN-2884 & PWWO-16 & 400 & 7,700 & -100 & 44.1 & 15.594 & 18.474 \\
\hline WIN-2885 & PWWO-17 & 400 & 7,700 & -50 & 82.9 & 16.248 & 20.437 \\
\hline WIN-2886 & PWWO-18 & 400 & 7,700 & 0 & 111.3 & 13.973 & 18.347 \\
\hline WIN-2887 & PWWO-19 & 400 & 7,700 & 25 & 126.3 & 14.412 & 18.221 \\
\hline WIN-2888 & PWWO-20 & 400 & 7,700 & 25 & 130.9 & 13.397 & 17.879 \\
\hline WIN-2893 & PWWO-21 & 400 & 7,700 & 75 & 157.4 & 13.163 & 17.430 \\
\hline WIN-2894 & PWWO-22 & 400 & 7,700 & 150 & 143.4 & 11.512 & 15.428 \\
\hline WIN-2895 & PWWO-23 & 400 & 7,700 & 200 & 152.4 & 11.542 & 15.340 \\
\hline WIN-2896 & PWWO-24 & 400 & 7,700 & 290 & 121.8 & 9.540 & 13.153 \\
\hline WIN-2897 & PWWO-25 & 400 & 7,700 & 290 & 151.9 & 10.575 & 14.305 \\
\hline CS-2861 & PWC & 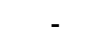 & - & 25 & 255.6 & 12 & 18.855 \\
\hline CS-2862 & PWCE-06 & - & - & 25 & 281.9 & 11.776 & 18.533 \\
\hline WIN-2889 & PWCE-09 & 400 & 10,000 & 25 & 187.2 & 13.524 & 19.011 \\
\hline WIN-2890 & PWCE-10 & 400 & 10,000 & 25 & 149.3 & 12.167 & 17.937 \\
\hline CS-2869 & PWCE-07 & - & - & 290 & 340.5 & 9.149 & 12.577 \\
\hline CS-2870 & PWCE-08 & - & - & 290 & 366.0 & 7.890 & 12.430 \\
\hline WIN-2898 & PWCE-11 & 400 & 10,000 & 290 & 291.7 & 10.155 & 14.178 \\
\hline WIN-2899 & PWCE-12 & 400 & 10,000 & 290 & 250.8 & 8.544 & 14.334 \\
\hline CS-2865 & PWDR- & - & - & 25 & 138.7 & 12.616 & 17.537 \\
\hline CS-2866 & PWDR-07 & - & - & 25 & 140.2 & 12.791 & 17.859 \\
\hline WIN-2891 & PWDR-01 & 400 & 10,000 & 25 & 78.8 & 12.938 & 15.184 \\
\hline WIN-2892 & PWDR-02 & 400 & 10,000 & 25 & 84.4 & 12.821 & 15.028 \\
\hline CS-2873 & PWDR-08 & & 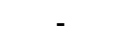 & 290 & 148.4 & 8.310 & 11.893 \\
\hline CS-2874 & PWDR-09 & - & - & 290 & 189.5 & 8.515 & 12.596 \\
\hline WIN-2900 & PWDR-03 & 400 & 10,000 & 290 & 93.4 & 8.583 & 11.493 \\
\hline WIN-2901 & PWDR-04 & 400 & 10,000 & 290 & 102.4 & 8.866 & 12.303 \\
\hline CS-2859 & PWN & 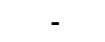 & - & 25 & 191.4 & 13 & 18.953 \\
\hline CS-2860 & PWMS-02 & 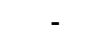 & - & 25 & 185.6 & 13.504 & 18.861 \\
\hline CS-2867 & PWMS-03 & - & - & 290 & 202.7 & 9.872 & 13.524 \\
\hline CS-2868 & PWMS-04 & - & - & 290 & 186.9 & 9.159 & 12.977 \\
\hline
\end{tabular}




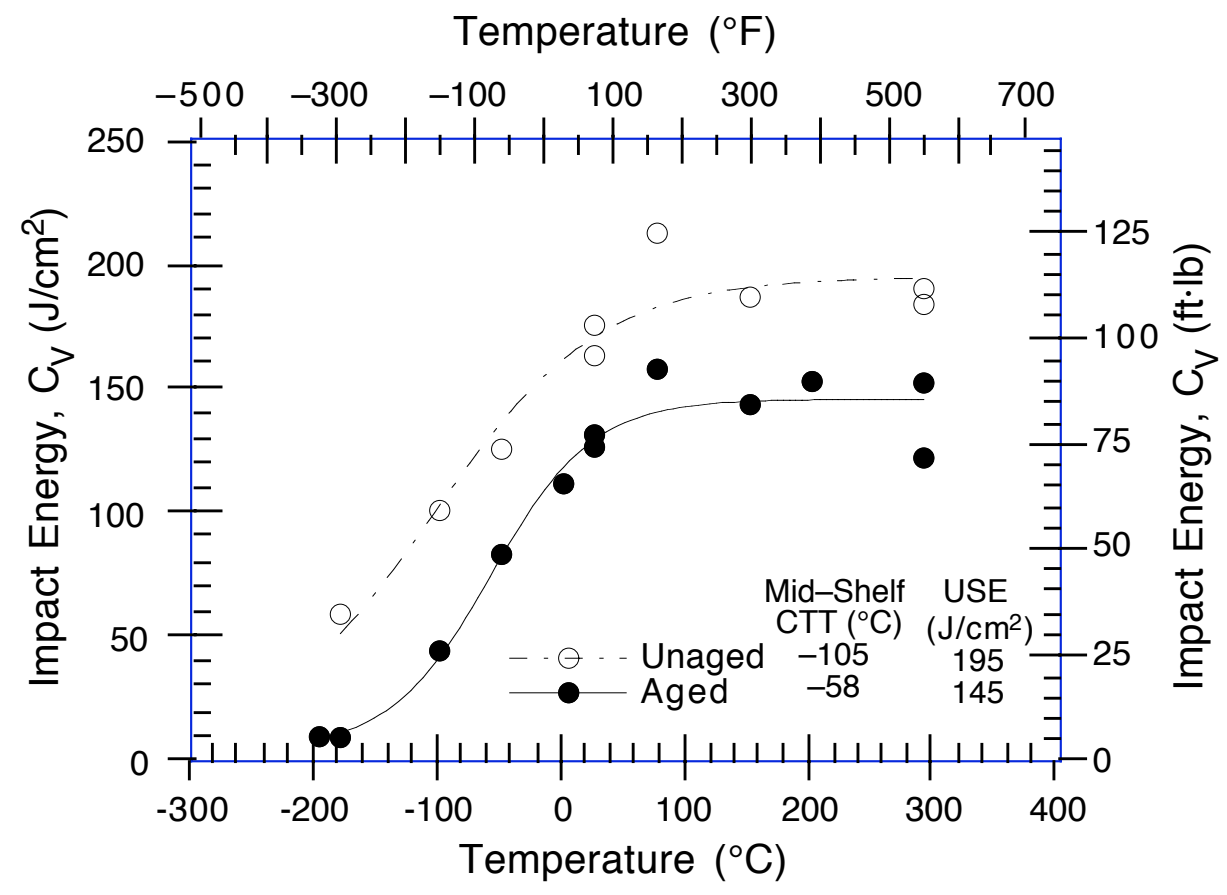

Figure 6. Effect of thermal aging on Charpy-transition curve for PWWO weld
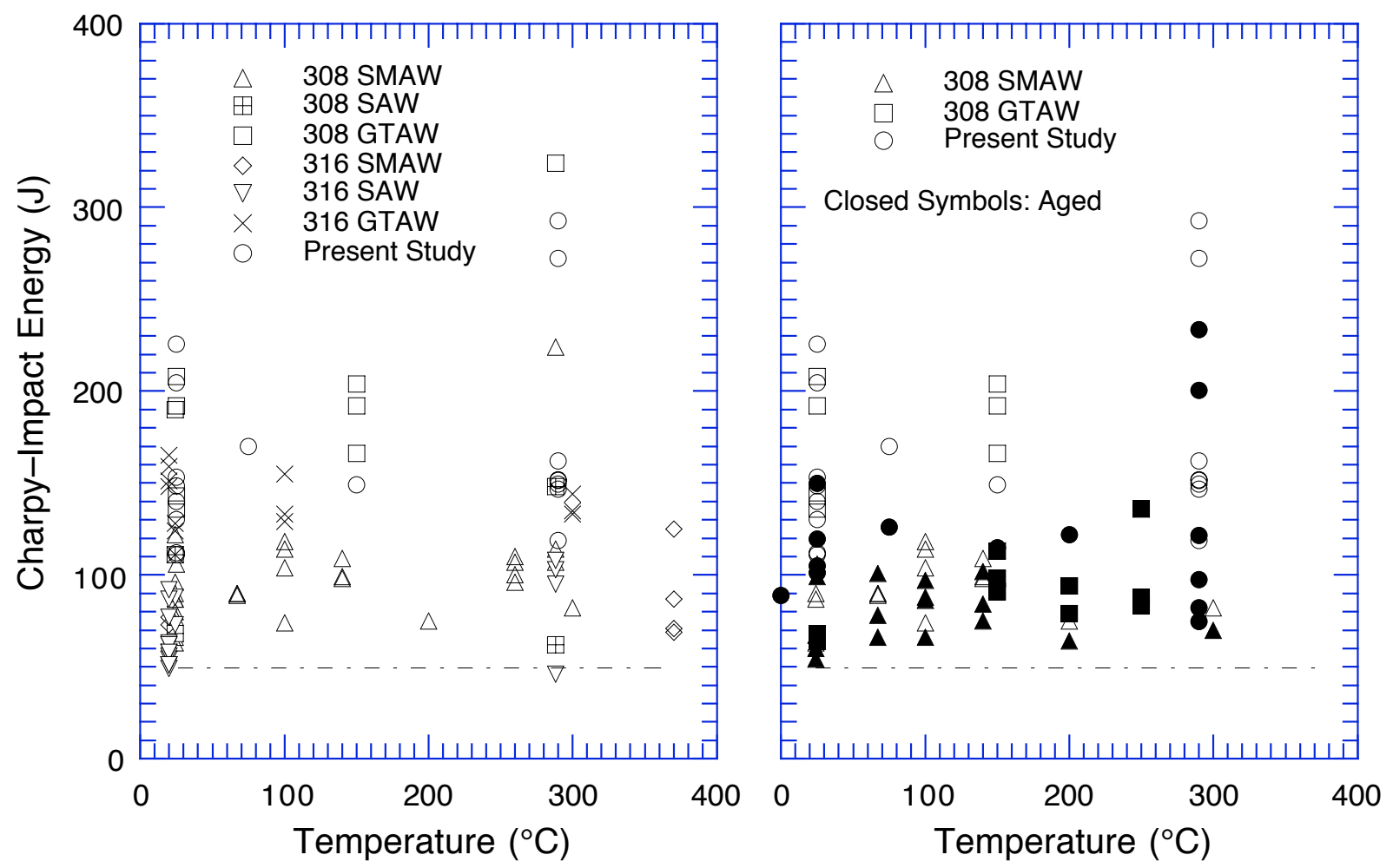

Figure 7. Charpy-impact energy of unaged and aged stainless steel welds 
Table 3. Summary of mechanical-property data for austenitic stainless steel welds

\begin{tabular}{|c|c|c|c|c|c|c|c|c|c|c|c|}
\hline Authors & Ref. & $\begin{array}{c}\text { Mater. } \\
\& \\
\text { Process } \\
\end{array}$ & $\begin{array}{c}\text { Heat } \\
\text { Treat- } \\
\text { ment }^{b}\end{array}$ & $\begin{array}{c}\text { Ferrite } \\
\text { Content } \\
(\mathrm{FN} / \%) \\
\end{array}$ & $\begin{array}{l}\text { Test } \\
\text { Temp. } \\
\left({ }^{\circ} \mathrm{C}\right)^{\mathrm{C}} \\
\end{array}$ & $\begin{array}{c}\text { Impact } \\
\text { Energy } \\
(\mathrm{J})^{d}\end{array}$ & $\begin{array}{c}\text { Yield } \\
\text { Strength } \\
(\mathrm{MPa})\end{array}$ & $\begin{array}{l}\text { Ultin } \\
\text { Stre } \\
\text { (MF } \\
\end{array}$ & $\begin{array}{l}\text { nate } \\
\text { ngth } \\
\text { a) }\end{array}$ & $\begin{array}{c}J_{I C} \\
\left(k J / m^{2}\right) \\
\end{array}$ & $\begin{array}{c}\text { Tearing } \\
\text { Modulus }\end{array}$ \\
\hline \multirow[t]{8}{*}{ Horn, et al. } & 22 & 308, SMAW & - & & RT & $\begin{array}{l}122 \\
111\end{array}$ & - & - & & - & - \\
\hline & & & & & 288 & 107 & 315 & 449 & & 194,215 & - \\
\hline & & & SA & & RT & & - & - & & - & - \\
\hline & & & & & 288 & 224 & 192 & 425 & & 169 & - \\
\hline & & 316, SAW & - & & RT & 73 & - & - & & - & - \\
\hline & & & & & 288 & 95,103 & 309 & 434 & & 170 & - \\
\hline & & & SA & & $\mathrm{RT}$ & - & - & - & & - & - \\
\hline & & & & & 288 & 108 & 192 & 401 & & 221 & - \\
\hline \multirow[t]{4}{*}{ Chipperfield } & 24 & 316, SMAW & - & $7.0-9.0$ & 370 & 71 & 401 & 486 & & 56 & - \\
\hline & & & a & $3.5-6.5$ & 370 & 69 & 286 & 431 & & $42, \quad 50$ & - \\
\hline & & & $b$ & $1.0-3.0$ & 370 & 87 & 261 & 423 & & 40 & - \\
\hline & & & c & $0-0.5$ & 370 & 125 & 184 & 449 & & 67 & - \\
\hline \multirow[t]{12}{*}{ Ould, et al. } & 25 & 316L, MMAW/ & I & 8.5 & 20 & 63,54 & 468 & 605 & & - & - \\
\hline & & SAW & & & 343 & - & 356 & 471 & & - & - \\
\hline & & & $\mathrm{F}$ & 7.5 & 20 & 51,62 & 465 & 613 & & - & - \\
\hline & & & & & 343 & & 375 & 474 & & - & - \\
\hline & & & $\mathrm{H} 1$ & 7.5 & 20 & 56,58 & 425 & 592 & & $147, \quad 16 \varepsilon$ & - \\
\hline & & & & & 343 & - & 379 & 464 & & - & - \\
\hline & & 308L, MMAW/ & C & 6.0 & 20 & 62,51 & $439, \quad 452$ & 541 & 544 & - & - \\
\hline & & SAW & & & 343 & - & $344, \quad 363$ & 391, & 390 & - & - \\
\hline & & & $\mathrm{B}$ & 6.0 & 20 & 49,51 & $420, \quad 436$ & 535 & 545 & 153 & - \\
\hline & & & & & 343 & - & $325, \quad 341$ & 385 & 390 & - & - \\
\hline & & & $\mathrm{D}$ & 5.0 & 20 & 58,51 & 398 & 563 & & 130 & - \\
\hline & & & & & 343 & - & $324, \quad 345$ & 394 & 431 & - & - \\
\hline \multirow{8}{*}{$\begin{array}{l}\text { Landes \& } \\
\text { McCabe }\end{array}$} & 26 & 308, SAW & - & & 24 & 111,68 & 348 & 600 & & 81 & 190 \\
\hline & & & & & 288 & 148,62 & 248 & 426 & & 47 & 150 \\
\hline & & 308, GTAW & - & & 24 & 190 & 354,475 & 595 & 624 & 195 & 610 \\
\hline & & & & & 288 & 324 & $239, \quad 372$ & 429 & 437 & 558 & 500 \\
\hline & & 308, SMAW & - & & 24 & 96 & $432, \quad 414$ & 605 & 597 & 259 & 170 \\
\hline & & & & & 288 & 114 & $323, \quad 341$ & 423 & 446 & 168 & 140 \\
\hline & & 316, SAW & - & & 24 & 88 & 414 & 633 & & 116 & 120 \\
\hline & & & & & 288 & 46 & 281 & 485 & & 105 & 90 \\
\hline \multirow[t]{15}{*}{ Mills } & 27 & 308, SMAW & - & 6.8 & 24 & - & 455 & 634 & & - & - \\
\hline & 28 & & & & 427 & - & 323 & 472 & & $154 \pm 41$ & 310 \\
\hline & 29 & & & & 538 & - & 303 & 412 & & $154 \pm 41$ & 310 \\
\hline & & 308, GTAW & - & 9.9 & 427 & - & 278 & 477 & & $266 \pm 20$ & 373 \\
\hline & & & & & 538 & - & 268 & 401 & & $266 \pm 20$ & 373 \\
\hline & & 308, SAW & - & 10.7 & 24 & - & 365 & 627 & & $198 \pm 17$ & 107 \\
\hline & & & & & 427 & - & 344 & 474 & & $76 \pm 17$ & 167 \\
\hline & & & & & 538 & - & 290 & 384 & & $76 \pm 17$ & 167 \\
\hline & & 16-8-2, GTAW & - & 5.7 & 24 & - & 360 & 668 & & $392 \pm 107$ & 7249 \\
\hline & & & & & 427 & - & 265 & 388 & & $266 \pm 20$ & 373 \\
\hline & & & & & 482 & - & 281 & 385 & & $266 \pm 20$ & 373 \\
\hline & & & & & 538 & - & 263 & 359 & & $266 \pm 20$ & 373 \\
\hline & & 16-8-2, SAW & - & 9.0 & 24 & - & 391 & 627 & & $198 \pm 17$ & 107 \\
\hline & & & & & 427 & - & 297 & 476 & & $76 \pm 17$ & 167 \\
\hline & & & & & 538 & - & 321 & 439 & & $76 \pm 17$ & 167 \\
\hline
\end{tabular}


Table 3. (Contd.)

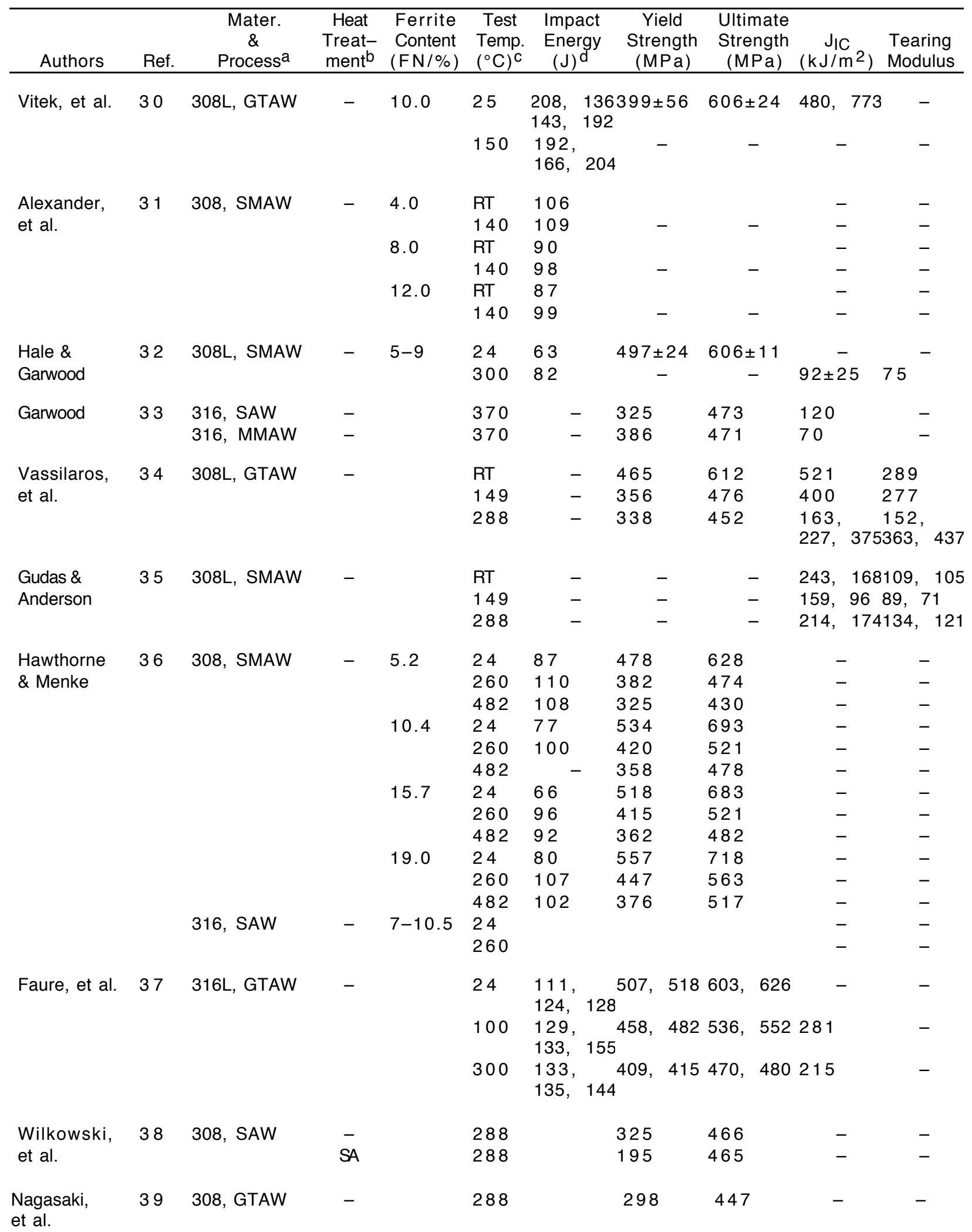


Table 3. (Contd.)

\begin{tabular}{|c|c|c|c|c|c|c|c|c|c|c|c|c|}
\hline Authors & Ref. & $\begin{array}{c}\text { Mater. } \\
\& \\
\text { Process } \\
\end{array}$ & $\begin{array}{c}\text { Heat } \\
\text { Treat- } \\
\text { ment }^{b}\end{array}$ & $\begin{array}{c}\text { Ferrite } \\
\text { Content } \\
(\mathrm{FN} / \%) \\
\end{array}$ & $\begin{array}{c}\text { Test } \\
\text { Temp. } \\
\left({ }^{\circ} \mathrm{C}\right)^{\mathrm{C}}\end{array}$ & $\begin{array}{c}\text { Impact } \\
\text { Energy } \\
(\mathrm{J})^{\mathrm{d}}\end{array}$ & & $\begin{array}{l}\text { Yield } \\
\text { trength } \\
\text { (MPa) } \\
\end{array}$ & $\begin{array}{r}\text { Ulti } \\
\text { Stre } \\
(\mathrm{M} \\
\end{array}$ & $\begin{array}{l}\text { mate } \\
\text { ength } \\
\mathrm{Pa} \text { ) } \\
\end{array}$ & $\begin{array}{c}J_{I C} \\
\left(k J / m^{2}\right) \\
\end{array}$ & $\begin{array}{l}\text { Tearing } \\
\text { Modulus } \\
\end{array}$ \\
\hline \multirow[t]{6}{*}{$\begin{array}{l}\text { European } \\
\text { Community }\end{array}$} & 40 & 316, GMAW & - & & 20 & $\begin{array}{ll}159, & 16 \\
148, & 16 \\
151, & 15\end{array}$ & $\begin{array}{l}5518, \\
5 \\
1\end{array}$ & 361 & 644, & 607 & - & - \\
\hline & & & & & 550 & $\begin{array}{ll}193, & 26 \\
209, & 20 \\
219, & 15\end{array}$ & $\begin{array}{l}4217, \\
9 \\
9\end{array}$ & 7, 151 & 428, & 402 & - & - \\
\hline & & 316, MMAW & - & & 20 & 77,73 & $\begin{array}{l}469 \\
428\end{array}$ & $\begin{array}{ll}\text {, } & 469 \\
3, & 437\end{array}$ & $\begin{array}{l}585 \\
608\end{array}$ & $\begin{array}{l}586 \\
608\end{array}$ & - & - \\
\hline & & & & & 550 & 77,82 & $\begin{array}{l}292 \\
178\end{array}$ & $\begin{array}{ll}2, & 307 \\
3, & 178\end{array}$ & $\begin{array}{l}403 \\
421\end{array}$ & $\begin{array}{l}413 \\
422\end{array}$ & - & - \\
\hline & & 316, SAW & - & & 20 & $\begin{array}{l}87,92, \\
77\end{array}$ & $\begin{array}{l}397, \\
405, \\
359,\end{array}$ & $\begin{array}{l}7, \quad 407 \\
, \quad 347 \\
9\end{array}$ & $\begin{array}{l}566, \\
567, \\
596\end{array}$ & $\begin{array}{l}568 \\
584 \\
590\end{array}$ & - & - \\
\hline & & & & & 550 & $\begin{array}{l}64,87, \\
87\end{array}$ & - & & - & & - & - \\
\hline
\end{tabular}

$50 \mathrm{~J}(37 \mathrm{ft} \cdot \mathrm{lb})$. The GTAWs generally exhibited higher impact strength than the SMAWs or SAWs. The results indicate that the welds that were investigated in the present study have relatively high impact strength; the PWCE weld exhibited the highest and PWDR the lowest impact strength.

In Fig. 7 the impact energies of aged welds25,30-32 fall within the large scatter band of the unaged welds. The results indicate that the effect of thermal aging on Charpy-impact strength depends on the initial impact strength of the welds. Welds with relatively high impact strength, e.g., the GTAWs, show a large decrease in impact energy whereas those with poor impact strength show minimal change in impact energy. Even in the saturation or fully embrittled condition, austenitic SS welds have $\geq 50 \mathrm{~J}(37 \mathrm{ft} \cdot \mathrm{lb})$ of impact energy.

Photomicrographs of the fracture surface of unaged and aged weld metal Charpy specimens tested at room temperature are shown in Fig. 8. The results indicate that the overall fracture behavior of the welds is controlled by the distribution and morphology of secondphase particles. All welds exhibit a dimple fracture. Failure occurs by nucleation and growth of microvoids and rupture of remaining ligaments. High-magnification photomicrographs of unaged and aged PWWO and PWDR specimens are presented in Fig. 9, which shows that nearly every dimple was initiated by decohesion of an inclusion (most likely manganese sili cide). The hard inclusions in the SMAW resist deformation and the buildup of high local stresses leads to decohesion of the particle/matrix interface. Inferior fracture resistance of the PWDR weld may be attributed to the higher density and larger size of inclusions relative to the PWWO or PWCE welds. Metallographic results suggest that the delta ferrite phase has relatively little effect on the fracture properties of the welds.

The results also indicate that thermal aging has no effect on fracture morphology of the specimens tested at room temperature; both unaged and aged welds exhibit a dimple fracture. 
Unaged

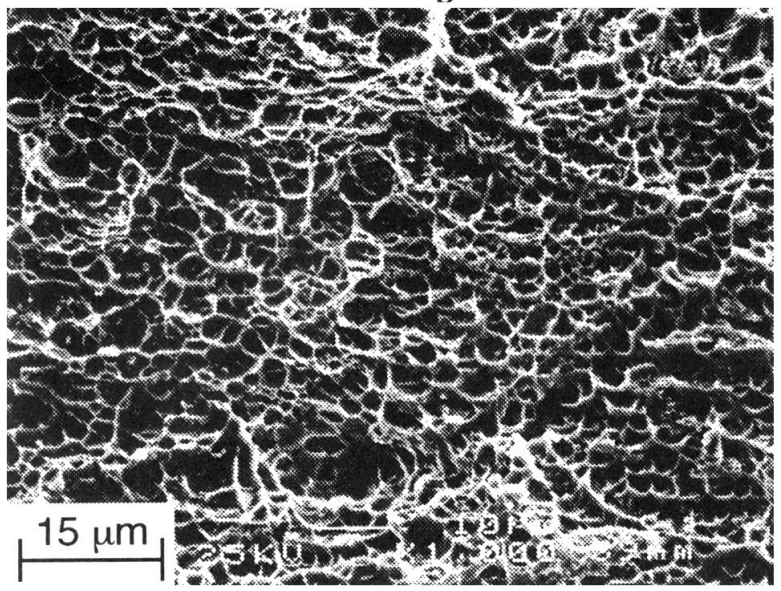

Aged

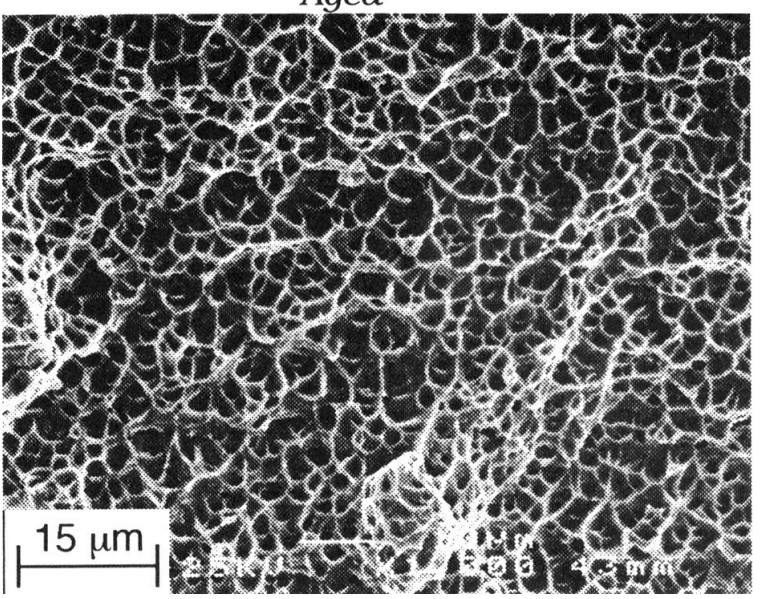

$P W C E$
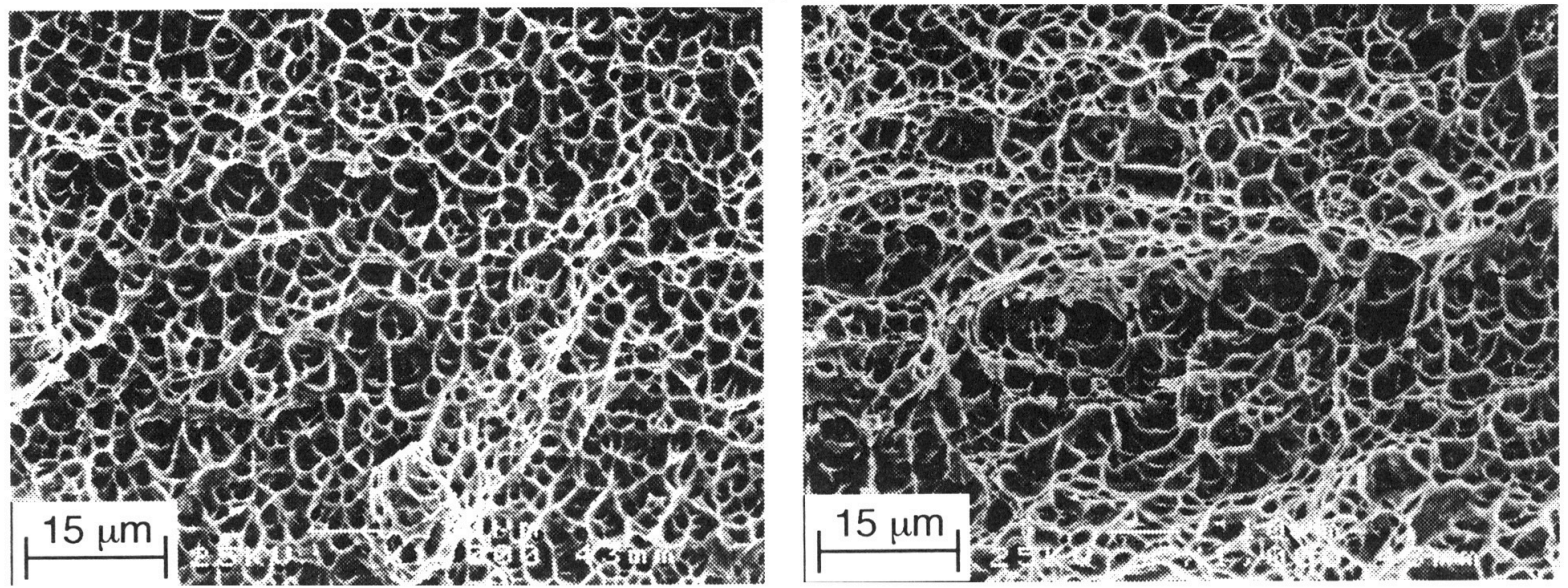

$P W W O$
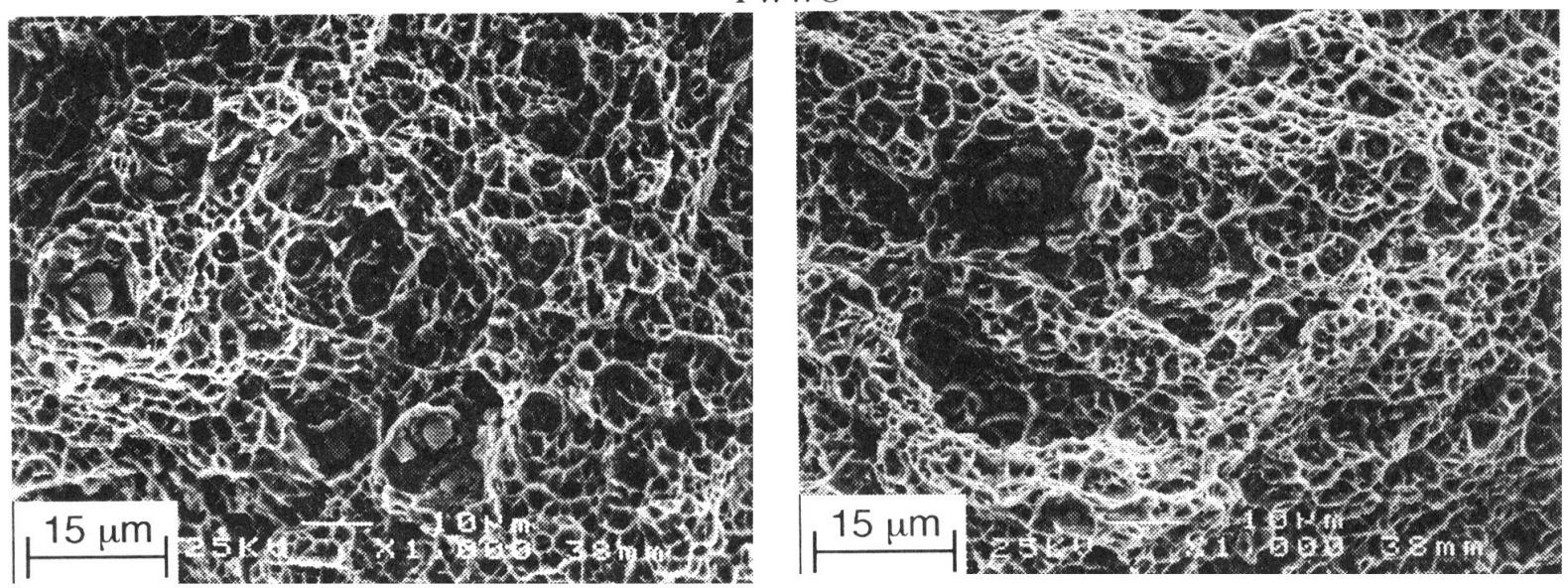

PWDR

Figure 8. Photomicrographs of fracture surface of unaged and aged Charpy specimens of various welds tested at room temperature 

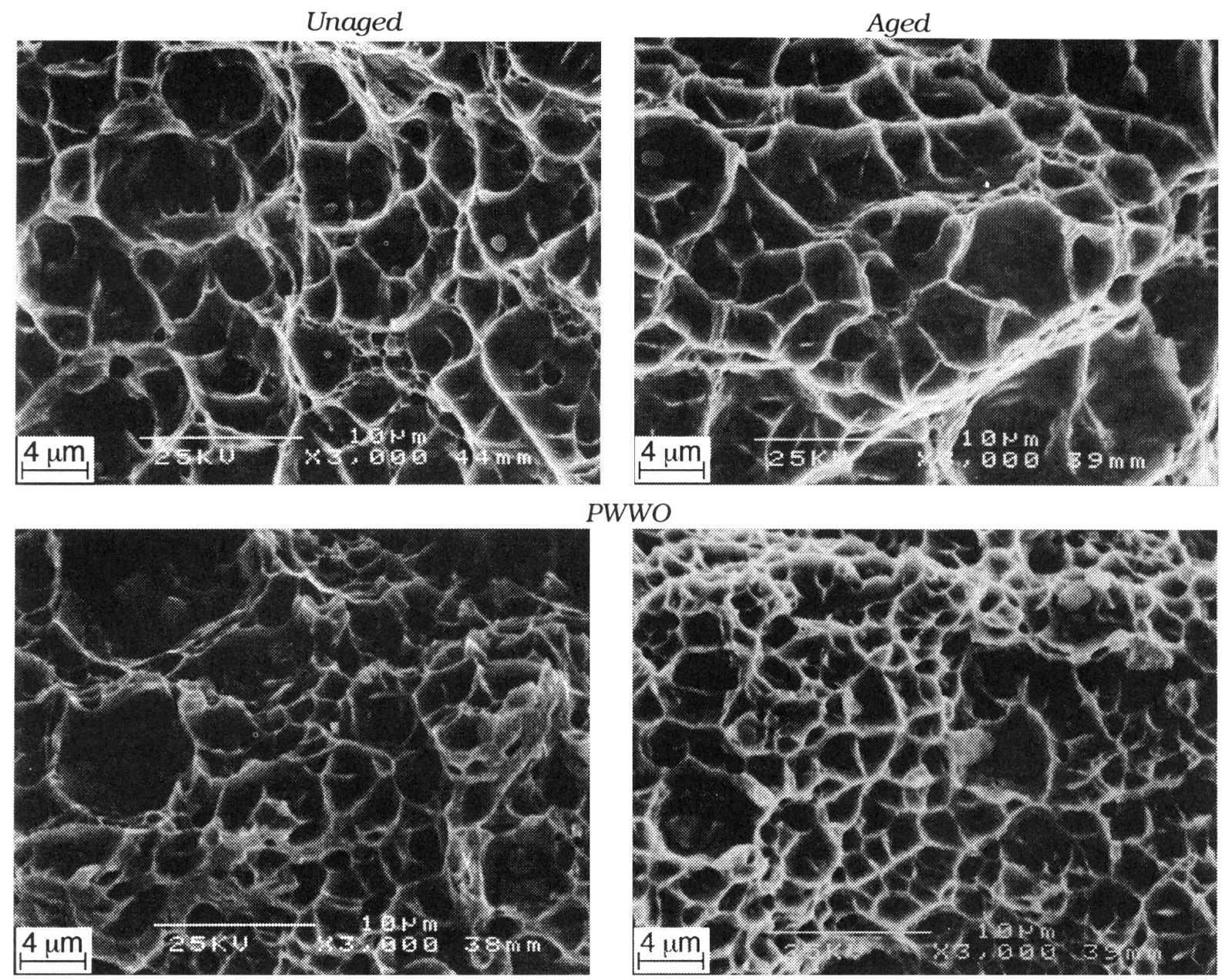

$P W W O$

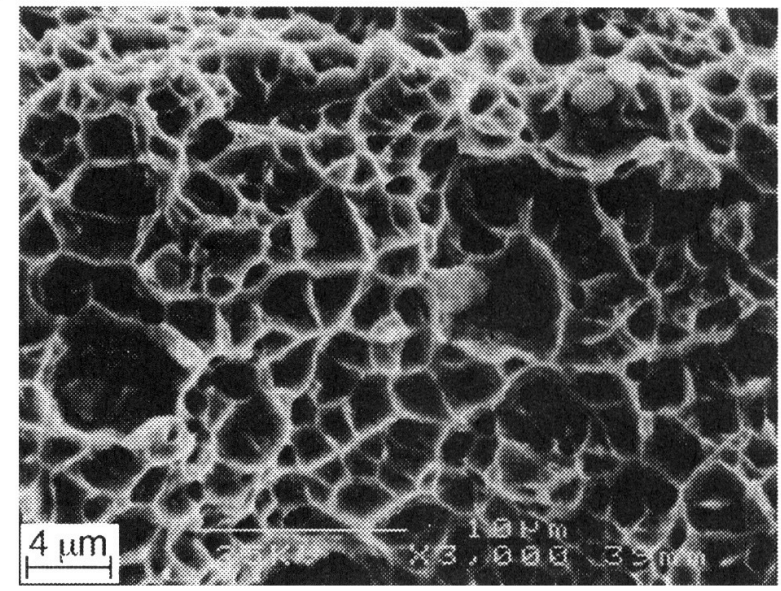

PWDR

Figure 9. Higher-magnification photomicrographs of fracture surface of unaged and aged Charpy specimens of PWWO and PWDR welds tested at room temperature

It is well known that thermal aging of duplex SSs results in brittle fracture associated with either cleavage of the ferrite or separation of the ferrite/austenite phase boundary.1,2,11 A brittle fracture was not observed in the welds, most probably because of the relatively low ferrite content and thin vermicular ferrite morphology. However, cleavage of the ferrite phase may occur at very low temperatures. Figure 10 shows cleavage of the ferrite phase in the unaged PWWO weld that was tested at $-180^{\circ} \mathrm{C}$. The amount of cleavage was slightly larger in the aged specimen than in the unaged specimen.

\subsection{Tensile Properties}

Tensile tests were not conducted on the welds; tensile properties of the welds were estimated from the Charpy-impact data. The values obtained for $0.2 \%$ yield and maximum load in each impact test are listed in Table 2, and may be used to estimate tensile properties of the cast materials. For a Charpy specimen, the yield stress $\sigma_{y}$ is estimated from the expression 


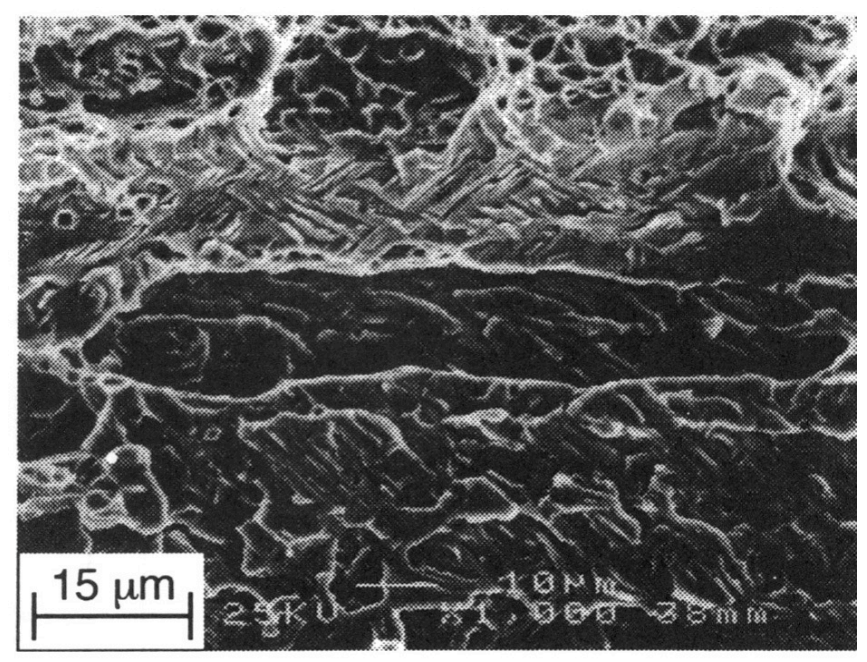

$$
\sigma_{y}=C_{1} P_{y} B / W b^{2}
$$

and the ultimate stress $\sigma_{u}$ is estimated from the expression

$$
\sigma_{\mathrm{u}}=\mathrm{C}_{2} \mathrm{P}_{\mathrm{m}} \mathrm{B} / \mathrm{W} \mathrm{b}^{2} \text {, }
$$

where $P_{y}$ and $P_{m}$ are the yield and maximum load, respectively, $W$ is the specimen width, $B$ is the specimen thickness, $b$ is the uncracked ligament, and $C_{1}$ and $C_{2}$ are constants. ${ }^{41}$ The yield and maximum loads were obtained from load-time traces of the Charpy tests. The constants $C_{1}$ and $C_{2}$ were determined by comparing the Charpy-impact test results with existing tensile properties data for Type 308 and 316 weld metals. The best value of the constants was 2.2 for both $C_{1}$ and $C_{2}$. The estimated yield and ultimate stress for the various welds are compared with existing data for Type 308 or 316 welds in Fig. 11. Average values of yield and ultimate stress for PWWO, PWCE, PWDR, and PWMS welds are listed in Table 4. Thermal aging has little or no effect on the tensile properties of Type 308 welds. These results are consistent with the data from other studies. $25,30-32$

Table 4. Tensile yield and ultimate stress of various stainless steel welds,

\begin{tabular}{|c|c|c|c|c|c|c|}
\hline \multirow[b]{2}{*}{$\begin{array}{c}\text { Material } \\
\text { ID }\end{array}$} & \multirow[b]{2}{*}{$\begin{array}{c}\text { Aging Temp. } \\
\left({ }^{\circ} \mathrm{C}\right)\end{array}$} & \multirow[b]{2}{*}{$\begin{array}{l}\text { Aging } \\
\text { Time }(\mathrm{h})\end{array}$} & \multicolumn{2}{|c|}{ Room Temp. } & \multicolumn{2}{|c|}{$290^{\circ} \mathrm{C}$} \\
\hline & & & $\begin{array}{c}\text { Yield Stress } \\
(\mathrm{MPa})\end{array}$ & $\begin{array}{c}\text { Ultimate } \\
\text { Stress (MPa) }\end{array}$ & $\begin{array}{c}\text { Yield Stress } \\
(\mathrm{MPa})\end{array}$ & $\begin{array}{c}\text { Ultimate } \\
\text { Stress (MPa) }\end{array}$ \\
\hline \multirow[t]{2}{*}{ PWCE } & - & - & 425 & 643 & 315 & 430 \\
\hline & 400 & 10,000 & 442 & 635 & 321 & 490 \\
\hline \multirow[t]{2}{*}{ PWWO } & - & - & 472 & 633 & 349 & 446 \\
\hline & 400 & 7,700 & 478 & 620 & 346 & 472 \\
\hline \multirow[t]{2}{*}{ PWDR } & - & - & 437 & 608 & 289 & 421 \\
\hline & 400 & 10,000 & 443 & 519 & 300 & 409 \\
\hline PWMS & - & - & 471 & 650 & 327 & 456 \\
\hline
\end{tabular}
estimated from Charpy-impact data 

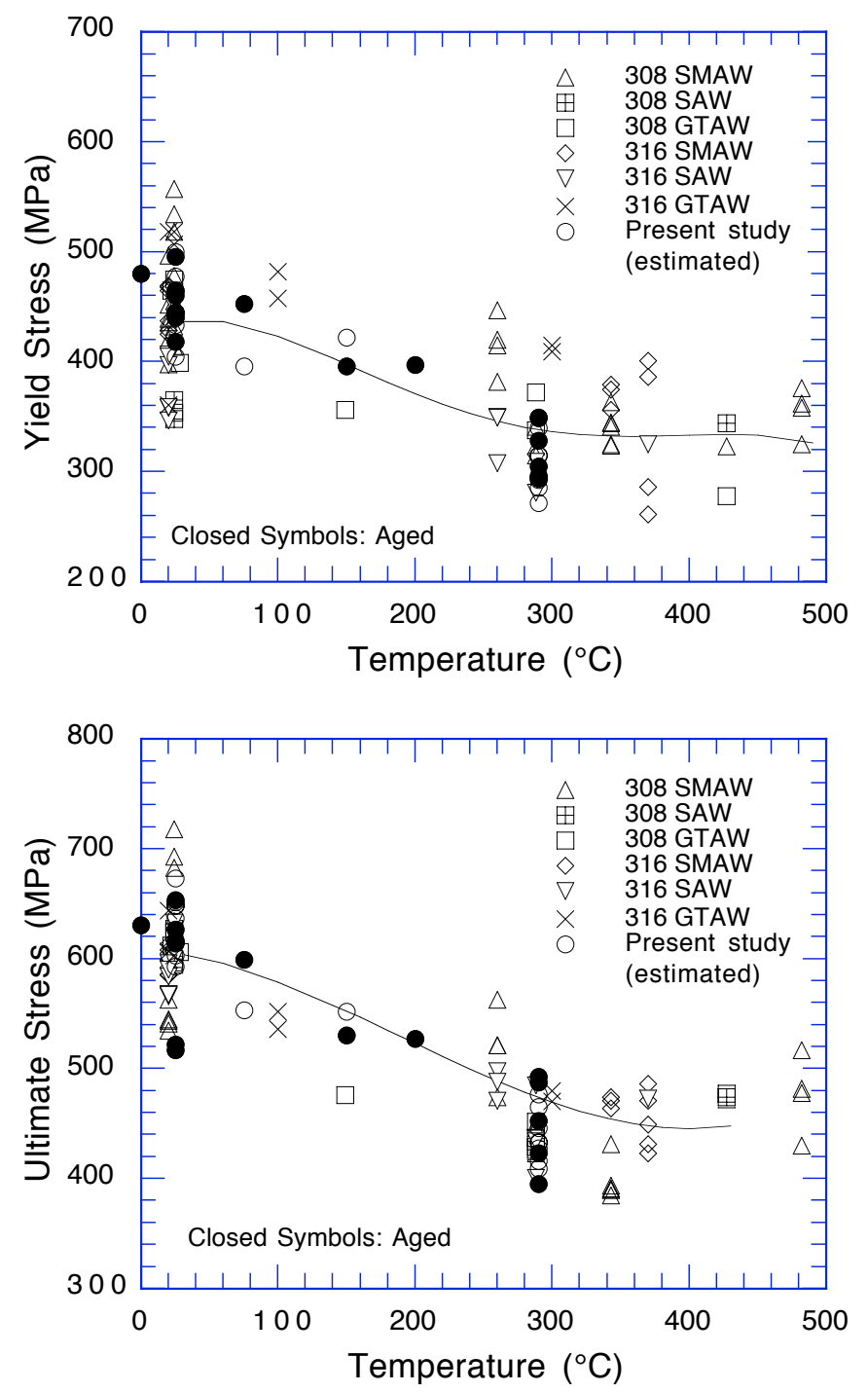

Figure 11. Tensile yield and ultimate stress of stainless steel welds. Solid lines are the best fit to the data.

\subsection{Fracture Toughness}

Fracture toughness $\mathrm{J}-\mathrm{R}$ curve tests were conducted at room temperature and $290^{\circ} \mathrm{C}$ on the PWWO, PWCE, and PWER welds. The fracture toughness results are given in Table 5. The effect of thermal aging on the fracture toughness $\mathrm{J}-\mathrm{R}$ curves of the various materials is shown in Figs. 12-14. The $J-R$ curves are expressed by the power-law relation $J_{d}=C(\Delta a)^{n}$ per ASTM Specifications E 813-85 and E 1152-87. The results indicate that, for all of the welds, the decrease in fracture toughness due to thermal aging is relatively small at room temperature and $290^{\circ} \mathrm{C}$. The fracture toughness data are consistent with the Charpy-impact test results. The fracture properties of SMAWs are controlled by the distribution and morphology of secondphase particles. In these welds, failure occurs by the formation and growth of microvoids near hard inclusions. Such processes are relatively insensitive to thermal aging. Fracture resis tance of the PWWO weld is inferior to that of the PWCE weld because of a higher density and a 


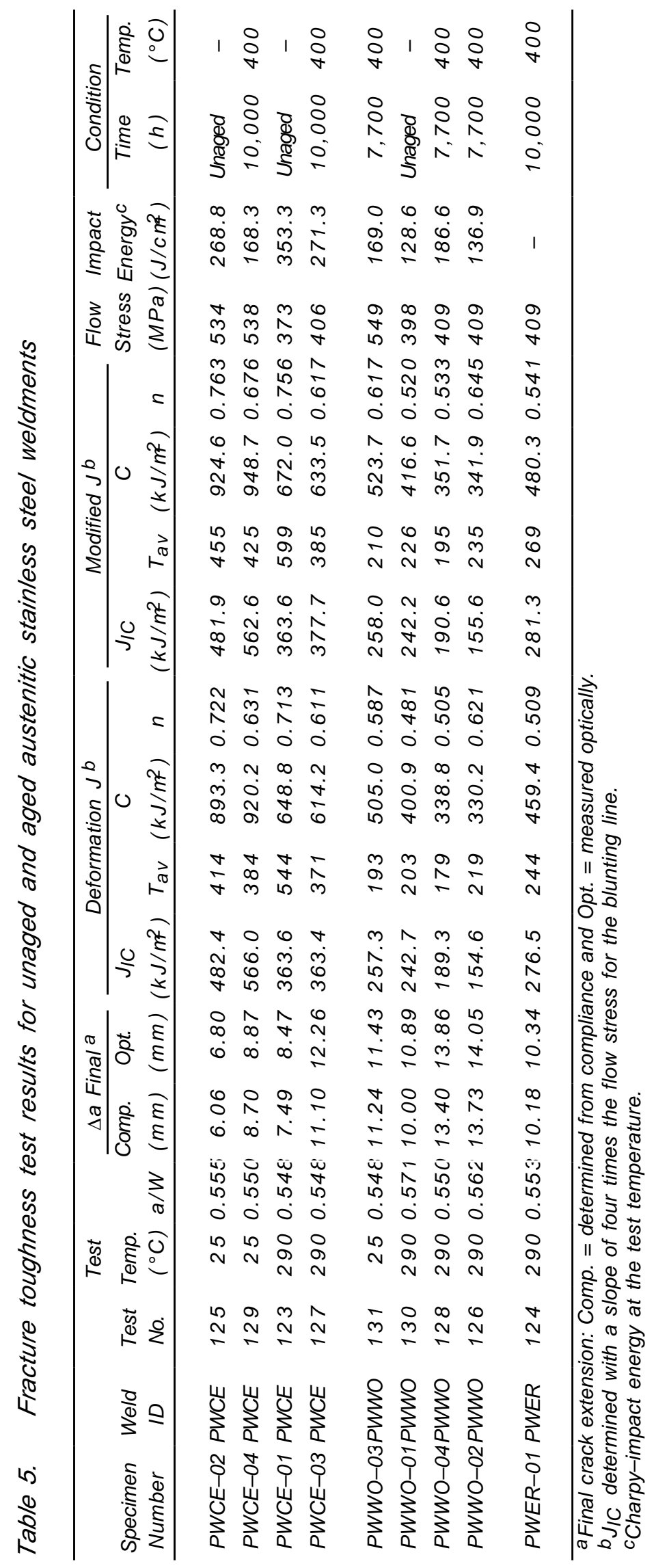



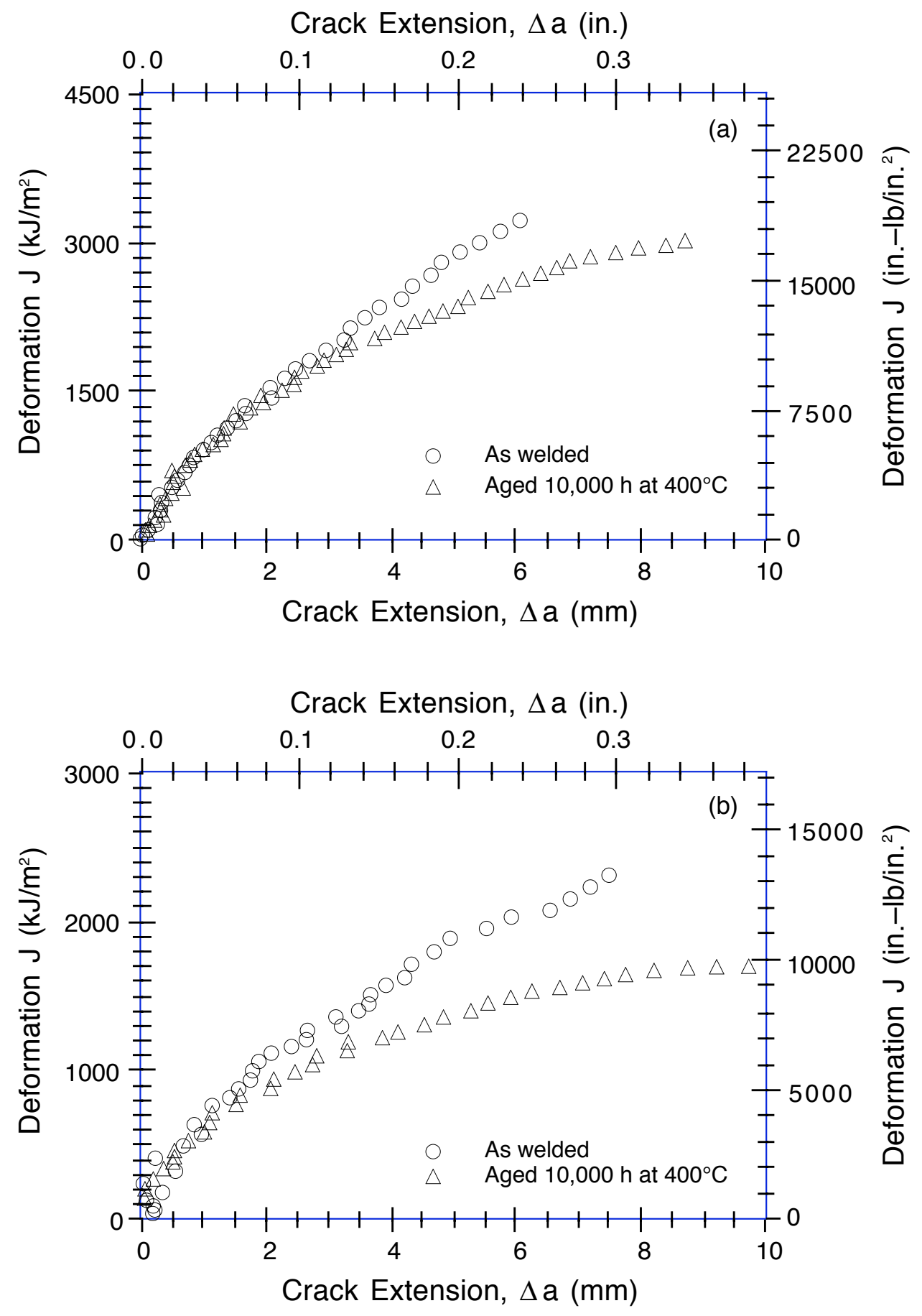

Figure 12. Fracture toughness $J-R$ curve for PWCE weld at (a) room temperature and (b) $290^{\circ} \mathrm{C}$ 

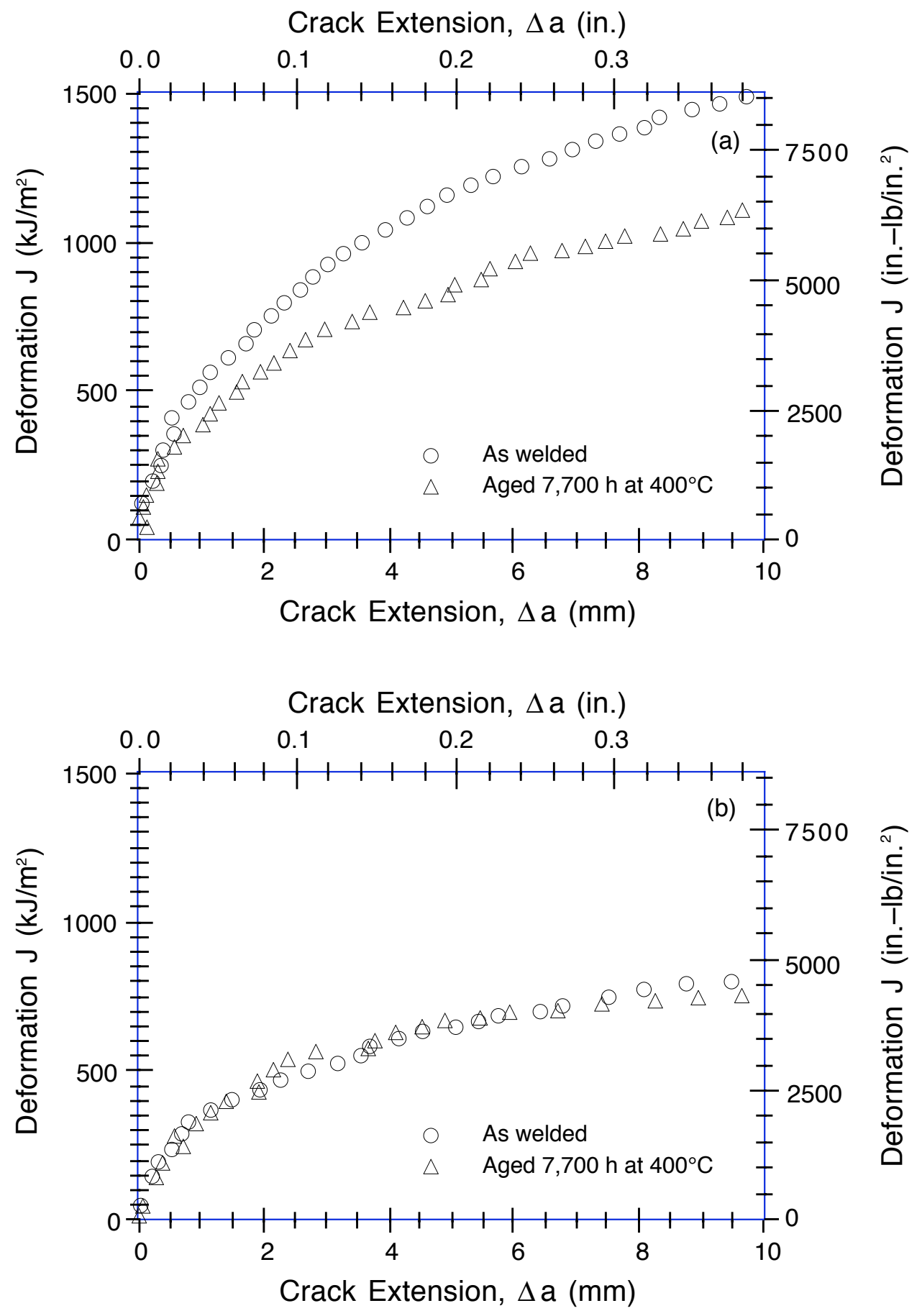

Figure 13. Fracture toughness $J-R$ curve for PWWO weld at (a) room temperature and (b) $290^{\circ} \mathrm{C}$ 


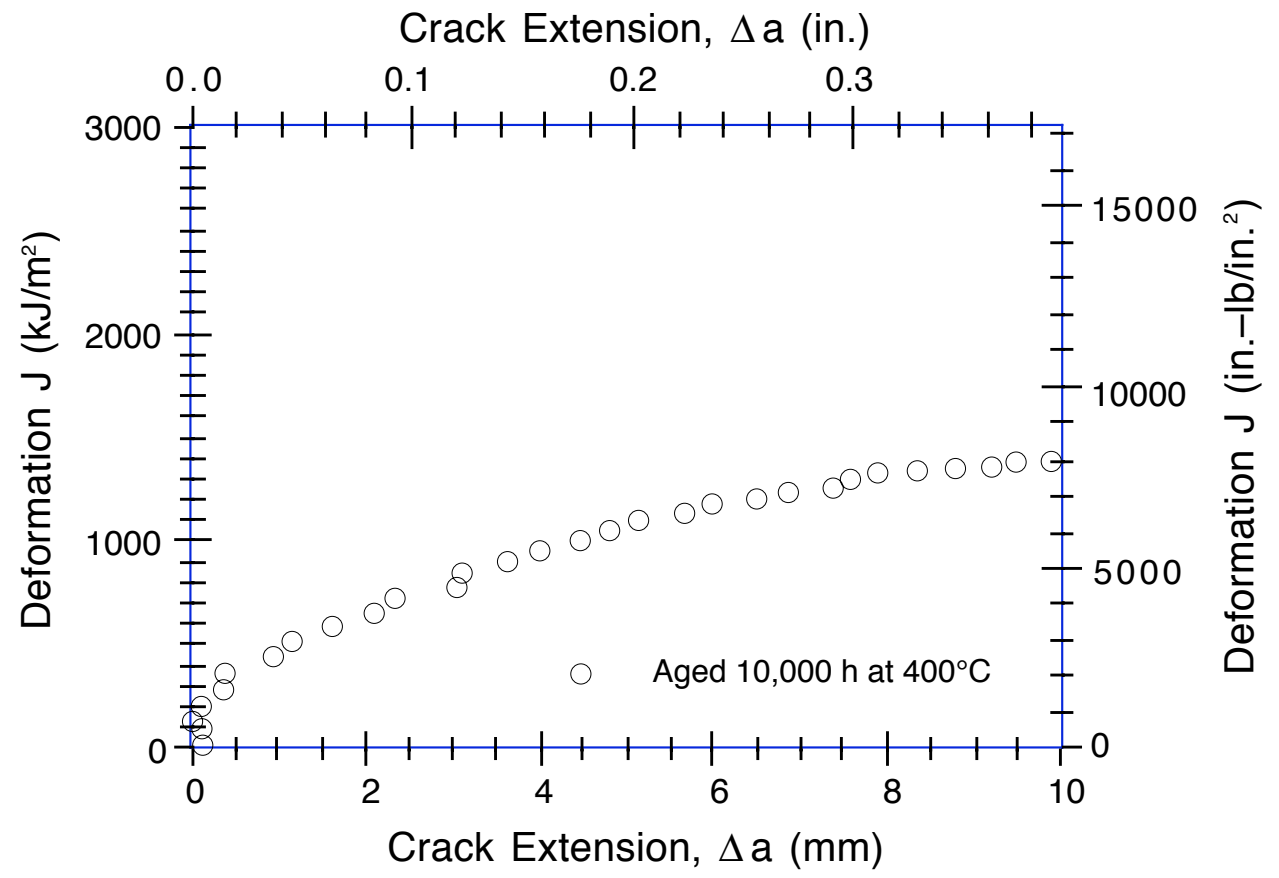

Figure 14. Fracture toughness J-R curve for PWER weld at $290^{\circ} \mathrm{C}$

larger size of inclusions. The ferrite phase has little or no effect on the fracture properties of the welds; ferrite is resistant to local failure because of its vermicular morphology and because it constitutes only $4-6 \%$ of the weld.

The existing fracture toughness J-R curve data from the work conducted for the U.S. Nuclear Regulatory Commission and compiled in the Pipe Fracture (PIFRAC) Database ${ }^{*}$ and from other sources,29,30,32-34,37 are shown in Fig. 15. The PIFRAC database, consisting of the data from Refs. 22, 26, 35, 38, and 39, was originally developed at Materials Engineering Associates (MEA), 42 and updated later by Battelle Memorial Institute. 43 The results indicate that fracture properties of SS welds are relatively insensitive to filler metal. ${ }^{29}$ However, the welding process significantly affects fracture toughness. In general, GTAWs exhibit higher fracture resistance than SMAWs or SAWs. The statistical differences in SAW and SMAW fracture toughness $\mathrm{J}-\mathrm{R}$ curves has also been evaluated 44 and results indicate no difference between SAW and SMAW J-R curves. At $288^{\circ} \mathrm{C}$, the lower-bound J-R curve for both SAWs and SMAWs, defined as the mean minus one standard deviation $\mathrm{J}-\mathrm{R}$ curve, 44 is represented by

$$
\mathrm{J}\left(\mathrm{kJ} / \mathrm{m}^{2}\right)=73.4+83.5 \Delta \mathrm{a}(\mathrm{mm})^{0.643}
$$

where $73.4 \mathrm{~kJ} / \mathrm{m}^{2}$ is the fracture toughness $\mathrm{J}_{\mathrm{IC}}$. The lower-bound curve for SAWs and SMAWs shows very good agreement with the data in Fig. 15. The fracture toughness data in the technical basis document for ASME Section XI Article IWB-3640 analysis, ${ }^{26}$ are somewhat higher than the curve given by Eq. 3 . The available fracture toughness J-R curves for aged SMAWs, SAWs, and GTAWs are shown in Fig. 16.25,28,32 In these studies, the time and temperature of aging was sufficient to achieve saturation toughness, i.e., the minimum value * G. Wilkowski and N. Ghadiali, "Short Crack in Piping and Piping Welds," in Technical Data CD-ROM, Battelle
Columbus Division, Columbus, OH (May 1995). 

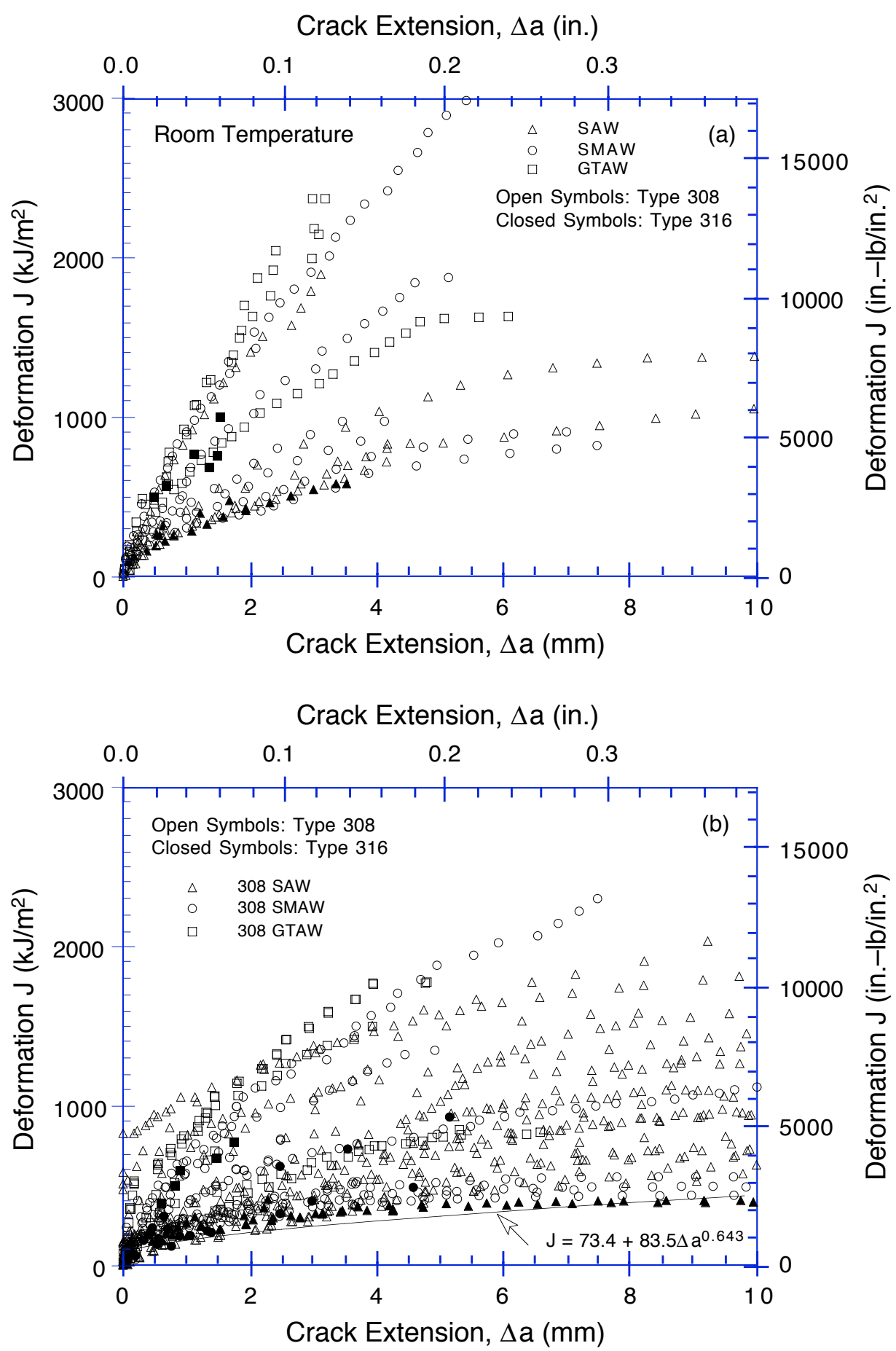

Figure 15. Fracture toughness $J-R$ curves for stainless steel welds at (a) room temperature and (b) $288-427^{\circ} \mathrm{C}$. Solid line represents lower-bound curve. 

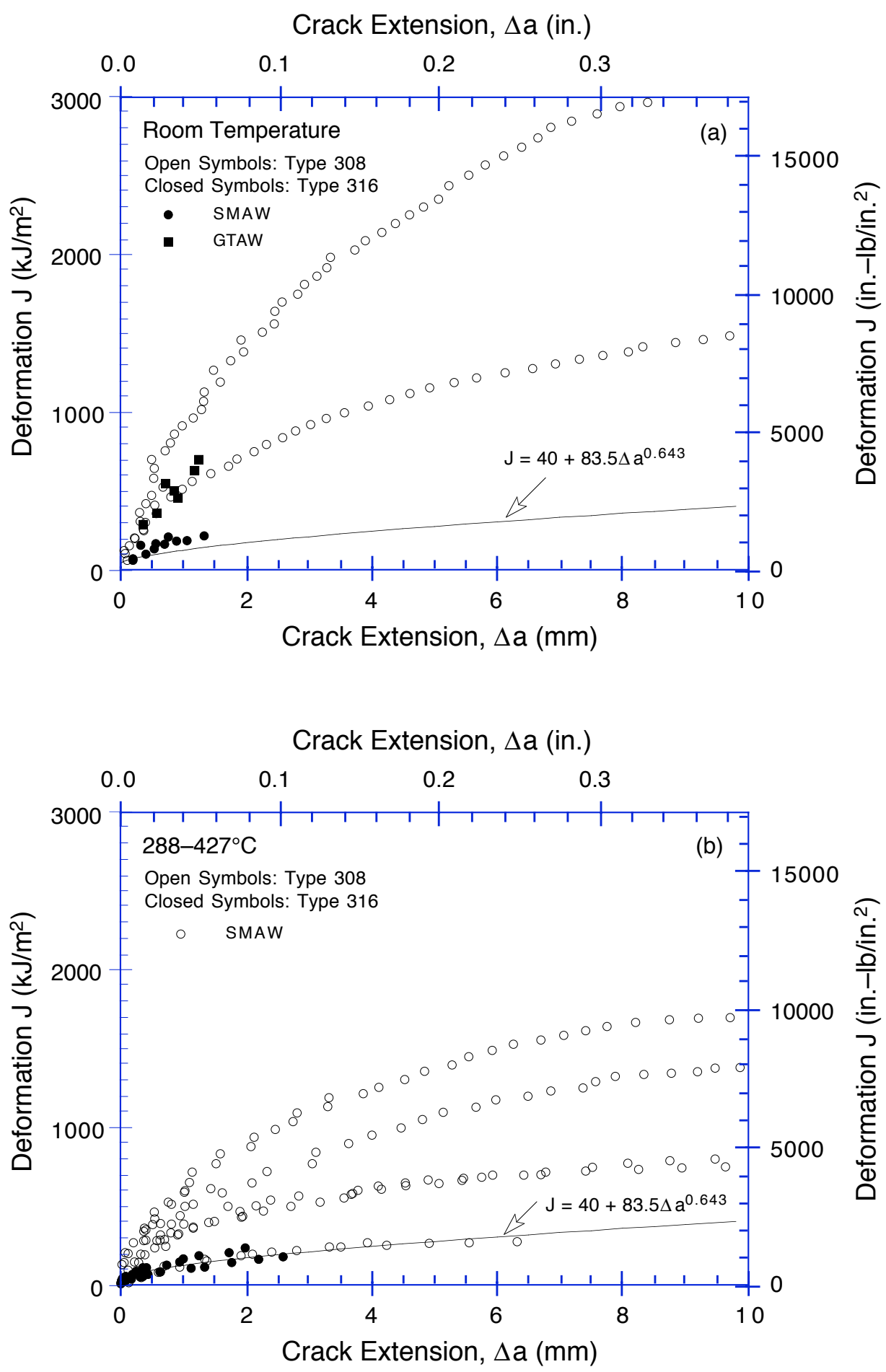

Figure 16. Fracture toughness $J-R$ curves for aged stainless steel welds at (a) room temperature and (b) $288^{\circ} \mathrm{C}$. Solid line represents lower-bound curve. 


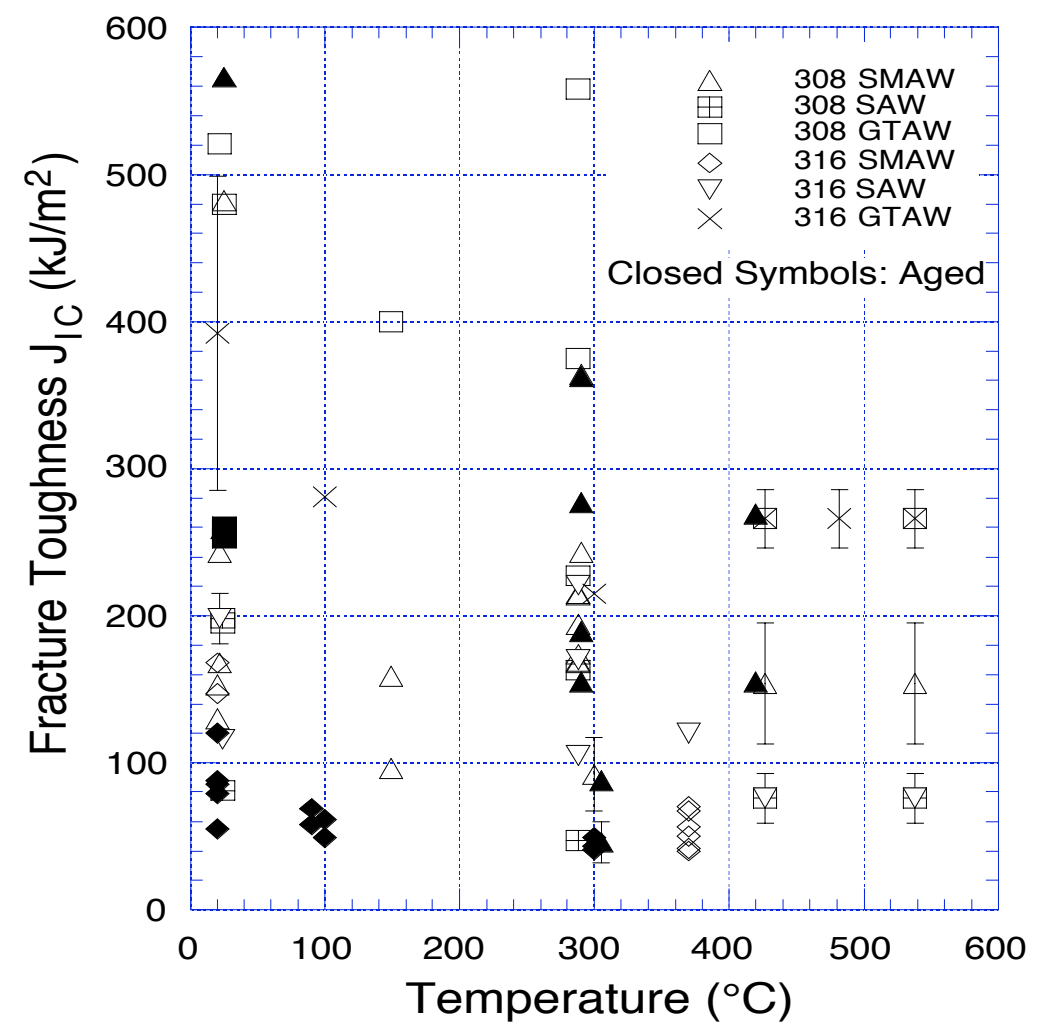

Figure 17. Fracture toughness J/C for unaged and aged stainless steel welds

that could be achieved after long-term aging. The $J_{I C}$ values for unaged and aged welds are plotted in Fig. 17. At reactor temperatures, the fracture toughness $J_{I C}$ of $S S$ welds can be as low as $40 \mathrm{~kJ} / \mathrm{m}^{2}$. Hence, the fracture toughness $\mathrm{J}-\mathrm{R}$ curves for fully embrittled SMAWs and SAWs can be slightly lower than that predicted by Eq. 3; a conservative estimate for aged welds may be expressed as

$$
\mathrm{J}\left(\mathrm{kJ} / \mathrm{m}^{2}\right)=40+83.5 \Delta \mathrm{a}(\mathrm{mm})^{0.643} .
$$

This curve is plotted in Fig. 16. The fracture toughness $\mathrm{J}-\mathrm{R}$ curves for unaged and aged SS welds, i.e., Eqs. 3 and 4, respectively, are compared in Fig. 18 with the data for aged 316L and CF-3 welds 24,32 and the data in the technical basis document for ASME Section XI Article IWB-3640.26 Note that the data from Ref. 26 are Jmodified rather than deformation J. The J-R curve suggested in Ref. 26 is somewhat higher than those predicted by Eqs. 3 and 4.

\section{Conclusions}

Thermal-aging-induced degradation of fracture toughness and Charpy-impact properties of several Type 304 SS pipe welds has been characterized at room temperature and $290^{\circ} \mathrm{C}$. Thermal aging of the welds resulted in moderate decreases in Charpy-impact strength and fracture toughness at both room temperature and $290^{\circ} \mathrm{C}$. For the various welds, USE decreased by $50-80 \mathrm{~J} / \mathrm{cm}^{2}(30-47 \mathrm{ft} \cdot \mathrm{lb}$.). The decrease in the fracture toughness $\mathrm{J}-\mathrm{R}$ curve or $\mathrm{JIC}$ is relatively small. Although tensile tests were not conducted on the welds, tensile proper- 


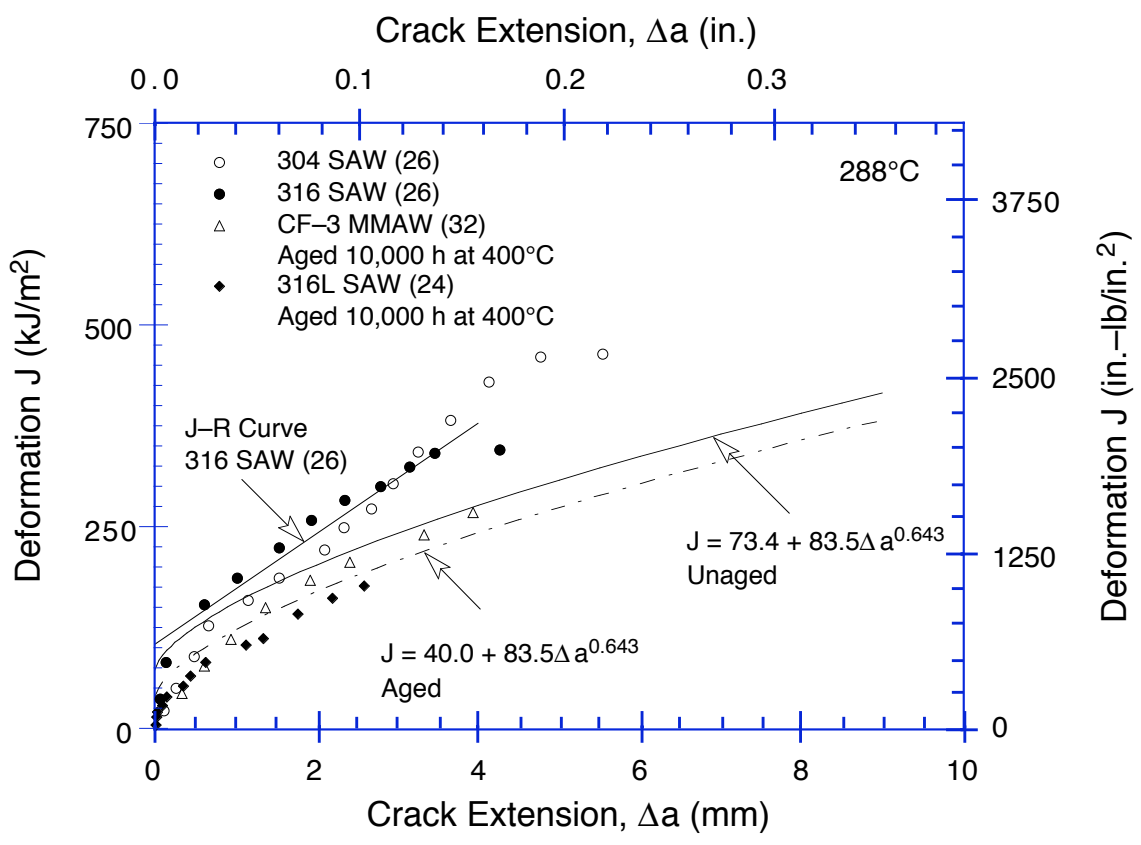

Figure 18. Fracture toughness $\mathrm{J}-R$ curves represented by Eqs. 3 and 4 and the data for aged $\mathrm{CF}-3$ and $316 \mathrm{~L}$ welds and that in the technical basis document for ASME Code IWB-3640 analysis

ties were estimated from the Charpy-impact data. The results indicate little or no effect of thermal aging on tensile strength of the welds. Metallographic examination of the specimens indicates that the fracture properties of SS welds are controlled by the distribution and morphology of second-phase particles. Differences in the fracture resistance of the welds arises from differences in the density and size of inclusions. Failure occurs by the formation and growth of microvoids near hard inclusions. In this study, the effect of thermal aging on fracture properties is minimal because of the relatively low ferrite content (4-6\% ferrite) and thin vermicular ferrite morphology in the welds.

The Charpy-impact, tensile, and fracture toughness results from this study have been compared with available data on SMAWs, SAWs, and GTAWs prepared with Types 308 or 316 SS filler metal. The data are consistent with results from other investigations. The fracture properties of SS welds are insensitive to filler metal. The welding process has a significant effect. The large variability in the data makes it difficult to establish the effect of the welding process on fracture properties of SS welds. In general, GTAWs exhibit higher fracture resistance than SMAWs or SAWs, and there is no difference between SAW and SMAW J-R curves. The Charpy-impact energy of some welds may be as low as $40 \mathrm{~J}$.

The results indicate that the decrease in impact strength due to aging depends on the ferrite content and initial impact strength of the weld. Welds with relatively high strength show a large decrease whereas those with poor strength show minimal change. In SS welds with poor strength, failure occurs by the formation and growth of microvoids. Such processes are relatively insensitive to thermal aging. The existing data indicate that at reactor temperatures, the fracture toughness $J_{I C}$ of thermally aged welds can be as low as $40 \mathrm{~kJ} / \mathrm{m}^{2}$. A conservative estimate of $\mathrm{J}-\mathrm{R}$ curve for aged $\mathrm{SS}$ welds may be given by $\mathrm{J}=40+83.5 \Delta \mathrm{a}^{0.643}$. 


\section{References}

1. O. K. Chopra and H. M. Chung, "Effect of Low-Temperature Aging on the Mechanical Properties of Cast Stainless Steels," in Properties of Stainless Steels in Elevated-Temperature Service, M. Prager, ed., MPC Vol. 26, PVP Vol. 132, ASME, New York, pp. 79-105 (1988).

2. O. K. Chopra, "Thermal Aging of Cast Stainless Steels: Mechanisms and Predictions," in Fatigue, Degradation, and Fracture - 1990, W. H. Bamford, C. Becht, S. Bhandari, J. D. Gilman, L. A. James, and M. Prager, eds., MPC Vol. 30, PVP Vol. 195, ASME, New York, pp. 193-214 (1990).

3. W. F. Michaud, P. T. Toben, W. K. Soppet, and O. K. Chopra, Tensile-Property Characterization of Thermally Aged Cast Stainless Stee/s, NUREG/CR-6142, ANL-93/35 (Feb. 1994).

4. A. Trautwein and W. Gysel, "Influence of Long-Time Aging of CF-8 and CF-8M Cast Steel at Temperatures Between 300 and $500^{\circ} \mathrm{C}$ on the Impact Toughness and the Structure Properties," in Spectrum, Technische Mitteilungen aus dem+GF+Konzern, No. 5 (May 1981); also in Stainless Steel Castings, V. G. Behal and A. S. Melilli, eds., STP 756, ASTM, Philadelphia, PA, pp. 165-189 (1982).

5. S. Bonnet, J. Bourgoin, J. Champredonde, D. Guttmann, and M. Guttmann, "Relationship between Evolution of Mechanical Properties of Various Cast Duplex Stainless Steels and Metallurgical and Aging Parameters: An Outline of Current EDF Programmes," Mater. Sci. Technol., 6, 221-229 (1990).

6. P. H. Pumphrey and K. N. Akhurst, "Aging Kinetics of CF3 Cast Stainless Steel in Temperature Range $300-400^{\circ} \mathrm{C}$, " Mater. Sci. Technol., 6, 211-219 (1990).

7. Y. Meyzaud, P. Ould, P. Balladon, M. Bethmont, and P. Soulat, "Tearing Resistance of Aged Cast Austenitic Stainless Steel," presented at Int. Conf. on Thermal Reactor Safety (NUCSAFE 88), Oct. 1988, Avignon, France.

8. H. M. Chung and O. K. Chopra, "Kinetics and Mechanism of Thermal Aging Embrittlement of Duplex Stainless Steels," in Environmental Degradation of Materials in Nuclear Power Systems-Water Reactors, G. J. Theus and J. R. Weeks, eds., The Metallurgical Society, Warrendale, PA, pp. 359-370 (1988).

9. P. Auger, F. Danoix, A. Menand, S. Bonnet, J. Bourgoin, and M. Guttmann, "Atom Probe and Transmission Electron Microscopy Study of Aging of Cast Duplex Stainless Steels," Mater. Sci. Technol., 6, 301-313 (1990).

10. M. Vrinat, P. Cozar, and Y. Meyzaud, "Precipitated Phases in the Ferrite of Aged Cast Duplex Stainless Steels," Scripta Metall., 2 0, 1101-1106 (1986). 
11. P. Joly, R. Cozar, and A. Pineau, "Effect of Crystallographic Orientation of Austenite on the Formation of Cleavage Cracks in Ferrite in an Aged Duplex Stainless Steel," Scripta Metall., 2 4, 2235-2240 (1990).

12. J. E. Brown, A. Cerezo, T. J. Godfrey, M. G. Hetherington, and G. D. W. Smith, "Quantitative Atom Probe Analysis of Spinodal Reaction in Ferrite Phase of Duplex Stainless Steel," Mater. Sci. Technol., 6, 293-300 (1990).

13. O. K. Chopra and W. J. Shack, Assessment of Thermal Embrittlement of Cast Stainless Stee/s, NUREG/CR-6177, ANL-94/2 (May 1994).

14. O. K. Chopra, Estimation of Fracture Toughness of Cast Stainless Steels during Thermal Aging in LWR Systems - Revision 1, NUREG/CR-4513 Rev. 1, ANL-93/22 (Aug. 1994).

15. O. K. Chopra, Long-Term Embrittlement of Cast Duplex Stainless Steels in LWR Systems: Semiannual Report October 1991-March 1992, NUREG/CR-4744, Vol. 7, No. 1, ANL-92/42 (April 1993).

16. L. S. Aubrey, P. F. Wieser, W. J. Pollard, and E. A. Schoefer, "Ferrite Measurement and Control in Cast Duplex Stainless Steel," in Stainless Steel Castings, V. G. Behal and A. S. Melilli, eds., ASTM STP 756, pp. 126-164 (1982).

17. P. S. Maiya and W. J. Shack, in Environmentally Assisted Cracking in Light Water Reactors: Annual Report, October 1983-September 1984, NUREG/CR-4287, ANL-85-33, pp. 67-70 (Aug. 1985).

18. J. Y. Park, in Environmentally Assisted Cracking in Light Water Reactors: Annual Report, October 1981-September 1982, NUREG/CR-3292, ANL-83-27, pp. 23-29 (Feb. 1983).

19. D. R. Diercks, Analysis of Cracked Core Spray Injection Line Piping from the Quad Cities Units 1 and 2 Boiling Water Reactors, Argonne National Laboratory Report ANL-83-99 (Dec. 1983).

20. P. S. Maiya and W. J. Shack, in Environmentally Assisted Cracking in Light Water Reactors: Annual Report, October 1983-September 1984, NUREG/CR-4287, ANL-85-33, pp. 67-70 (Aug. 1985).

21. S. Yukawa, Review and Evaluation of the Toughness of Austenitic Steels and Nickel Alloys After Long-Term Elevated Temperature Exposures, Welding Research Council Bulletin 378, New York (Jan. 1993).

22. R. M. Horn, H. S. Mehta, W. R. Andrews, and S. Ranganath, Evaluation of the Toughness of Austenitic Stainless Steel Pipe Weldments, EPRI NP-4668, Electric Power Research Institute, Palo Alto, CA (June 1986).

23. M. Strangwood and S. G. Druce, "Aging Effects in Welded Cast CF-3 Stainless Steel," Mater. Sci. Technol., 6, 237-248 (1990). 
24. C. G. Chipperfield, "A Toughness and Defect Size Assessment of Welded Stainless Steel Components," Tolerance of Flaws in Pressurized Components, Inst. Mech. Eng. pp. 125-137 (1978).

25. P. Ould, P. Balladon, and Y. Mehzaud, "Fracture Toughness of Austenitic Stainless Steel Welds," presented at Int. Colloquim on Stainless Stee/s, Ecole Polytechnique, Mons, Belgium, April 27-28, 1988.

26. J. D. Landes and D. E. McCabe, Toughness of Austenitic Stainless Steel Pipe Welds, EPRI NP-4768, Electric Power Research Institute, Palo Alto, CA (Oct. 1986).

27. W. J. Mills, Fracture Toughness Variations for Stainless Steel Base Metal and Welds, HEDL-TME 84-11, Hanford Engineering Development Laboratory, Richland, WA (May 1984).

28. W. J. Mills, "Fracture Toughness of Aged Stainless Steel Primary Piping and Reactor Vessel Materials," J. Press. Vessel Technol., 10 9, 440-448 (1987).

29. W. J. Mills, "Fracture Toughness of Stainless Steel Welds," in Fracture Mechanics: Nineteenth Symposium, T. A. Cruise, ed., ASTM STP 969, American Society for Testing and Materials, Philadelphia, PA, pp. 330-355 (1988).

30. J. M. Vitek, S. A. David, D. J. Alexander, J. R, Keiser, and R. K. Nanstad, "Low Temperature Aging Behavior of Type 308 Stainless Steel Weld Metal," Acta Metall., 3 9, 503-516 (1991).

31. D. J. Alexander, K. B. Alexander, M. K. Miller, and R. K. Nanstad, "The Effect of Aging at $343^{\circ} \mathrm{C}$ on Type 308 Stainless Steel Weldments," in Fatigue, Degradation, and Fracture 1990, W. H. Bamford, C. Becht, S. Bhandari, J. D. Gilman, L. A. James, and M. Prager, eds., MPC Vol. 30, PVP Vol. 195, ASME, New York, pp. 187-192 (1990).

32. G. E. Hale and S. J. Garwood, "Effect of Aging on Fracture Behaviour of Cast Stainless Steel and Weldments," Mater. Sci. Technol., 6, 230-236 (1990).

33. S. J. Garwood, "Fracture Toughness of Stainless Steel Weldments at Elevated Temperatures," in Fracture Mechanics: 15th Symposium, R. J. Sanford, ed., ASTM STP 833, American Society for Testing and Materials, Philadelphia, PA, pp. 333-359 (1984).

34. M. G. Vassilaros, R. A. Hays, and J. P. Gudas, "Investigation of the Ductile Fracture Properties of Type 304 Stainless Steel Plate, Welds, and 4-inch Pipe," in Proc. 12th Water Reactor Safety Research Information Meeting, NUREG/CP-0058, Vol. 4, U.S. Nuclear Regulatory Commission, pp. 176-189 (1985).

35. J. P. Gudas and D. R. Anderson, "JI-R Curve Characteristics of Piping Material and Welds," in Proc. 9th Water Reactor Safety Research Information Meeting, Oct. 1981, U.S. Nuclear Regulatory Commission.

36. J. R. Hawthorne and B. H. Menke, "Influence of Delta Ferrite Content and Welding Variables on Notch Toughness of Austenitic Stainless Steel Weldments," in Structural Materials for 
Service at Elevated Temperatures in Nuclear Power Generation, G. V. Smith, ed., MPC-1, ASME, New York, pp. 351-364 (1975).

37. F. Faure, B. Houssin, and P. Balladon, "Mechanical Properties of Automatic TIG/GTA Welds of Stainless Steel Piping in Nuclear Reactors," in Trends in Welding Research, ASM Conf., Gatlinburg, May 14-18, 1989.

38. G. Wilkowski, et al., Analysis of Experiments on Stainless Steel Flux Welds, NUREG/CR-4878, BMI-2151 (April 1987).

39. M. Nakagaki, C. Marshall, and F. Brust, Analysis of Cracks in Stainless Steel TIG Welds, NUREG/CR-4806, BMI-2144 (Dec. 1986).

40. Mechanical Testing of Austenitic Steel Welded Joints, Joint Final Report-Vol. 2, Commission of the European Communities, Ispra, Italy (1990).

41. W. L. Server, "Impact Three-Point Bend Testing for Notched and Precracked Specimens," J. Test. Eval., 6,29 (1978).

42. A. L. Hiser and G. M. Callahan, A User's Guide to the NRC's Piping Fracture Mechanics Database (PIFRAC), NUREG/CR-4894 (May 1987).

43. G. M. Wilkowski, et al., Short Crcaks in Piping and Piping Welds, NUREG/CR-4599, Vols. 1 to 3, Nos. 1 and 2 (May 1991 to March 1994).

44. G. M. Wilkowski, et al., Probabilistic Pipe Fracture Evaluations for Leak-Rate-Dectection Applications, NUREG/CR-6004 (April 1995). 


\section{Appendix}

\section{J-R Curve Characterization}

The J-R curve tests were performed according to ASTM Specifications E 813-85 (Standard Test Method for $\mathrm{J}_{\mathrm{IC}}$, a Measure of Fracture Toughness) and E 1152-87 (Standard Test Method for Determining J-R Curve). Compact-tension (CT) specimens, $25.4 \mathrm{~mm}$ (1 in.) thick with $10 \%$ side grooves, were used for the tests. The design of the CT specimen is similar to that of the specimen in ASTM Specification E 399, the notch region is modified in accordance with E 813 and E 5112, to permit measurement of load-line displacement by axial extensometer. The extensometer was mounted on razor blades that were screwed onto the specimen along the load line.

Prior to testing, the specimens were fatigue-precracked at room temperature and at load levels within the linear elastic range. The final ratio of crack length to width $(a / W)$ after pre-cracking was $\approx 0.55$. The final $1-\mathrm{mm}(\approx 0.04-$ in. $)$ crack extension was carried out at a load range of $13-1.3 \mathrm{kN}(2.92-0.292 \mathrm{kip})$, i.e., during precracking, $\mathrm{K}_{\max }$ was $<25 \mathrm{MPa} \cdot \mathrm{m}^{1 / 2}(22.6$ $\mathrm{ksi} \cdot \mathrm{in}^{1 / 2}$ ). After precracking, all specimens were side-grooved to $20 \%$ of the total specimen thickness, i.e., $10 \%$ per side, to ensure uniform crack growth during testing.

The J-R curve tests were performed on an Instron testing machine with $90 \mathrm{kN}$ (20 kip) maximum load capacity. The load and load-line displacement data were digitized with digital voltmeters and stored on a disk for posttest analysis and correction of test data. The single-specimen compliance procedure was used to estimate crack extension. Rotation and modulus corrections were applied to the compliance data. Both deformation theory and modified forms of the $\mathrm{J}$ integral were evaluated for each test.

After each test, the specimen was heated to $350^{\circ} \mathrm{C}$ to heat-tint the exposed fracture surface. The specimen was then fractured at liquid $\mathrm{N}$ temperature. The initial (i.e., fatigue precrack) and final (test) crack lengths were measured optically for both halves of the fractured specimen. The crack lengths were determined by the $9 / 8$ averaging technique, i.e., the two near-surface measurements were averaged and the resultant value was averaged with the remaining seven measurements.

The fracture toughness $J_{I C}$ values were determined in accordance with ASTM Specification $E$ 813-81 and E 813-85. For the former, $J_{I C}$ is defined as the intersection of the blunting line given by $\mathrm{J}=2 \sigma_{f} \Delta \mathrm{a}$, and the linear fit of the $\mathrm{J}-\mathrm{vs} .-\Delta \mathrm{a}$ test data between the $0.15-$ and $1.5-\mathrm{mm}$ exclusion lines. The flow stress $\sigma_{f}$, is the average of the $0.2 \%$ yield stress and the ultimate stress. The ASTM Specification E 813-85 procedure defines $J_{I C}$ as the intersection of the $0.2-\mathrm{mm}$ offset line with the power-law fit (of the form $\mathrm{J}=\mathrm{C} \Delta \mathrm{a}^{\mathrm{n}}$ ) of the test data between the exclusion lines. However, a slope of four times the flow stress $\left(4 \sigma_{f}\right)$ was used to define the blunting line. The tearing modulus was also evaluated for each test. The tearing modulus is given by $T=E(d J / d a) / \sigma_{f}{ }^{2}$, where $E$ is the Young's modulus and $\sigma_{f}$ is the flow stress. The ASTM E 813-81 value of tearing modulus is determined from the slope $\mathrm{dJ} / \mathrm{da}$ of the linear fit to the

$\mathrm{J}-\mathrm{vs} .-\Delta \mathrm{a}$ data. For the power-law curve fits, an average value of $\mathrm{dJ} / \mathrm{da}$ was calculated ${ }^{\mathrm{A}-1}$ to obtain the average tearing modulus. 
The test data, as well as an analysis and qualification of the data, are presented in Tables A-1 to A-27. Photographs of the fracture surface of the test specimens and deformation and modified $J-R$ curves for the various welds are shown in Figs. A-1 to A-27.

\section{Data Analysis Procedures}

The compliance method was used to determine crack length during the tests. The Hudak-Saxena calibration equation $\mathrm{A}-2$ was used to relate specimen load-line elastic compliance $\mathrm{C}_{\mathrm{i}}$ on an unloading/loading sequence with crack length $a_{i}$. The compliance, i.e., slope $(\Delta \delta / \Delta P)$ of the load-line displacement-vs.-load record obtained during the unloading/loading sequence, is given by

$$
\mathrm{U}_{\mathrm{LL}}=\frac{1}{\left(\mathrm{~B}_{\mathrm{e}} \mathrm{E}_{\mathrm{e}} \mathrm{C}_{\mathrm{i}}\right)^{1 / 2}+1}
$$

and

$$
\begin{aligned}
\mathrm{a}_{\mathrm{i}} / \mathrm{W}=1.000196 & -4.06319\left(\mathrm{U}_{\mathrm{LL}}\right)+11.242\left(\mathrm{U}_{\mathrm{LL}}\right)^{2}-106.043\left(\mathrm{U}_{\mathrm{LL}}\right)^{3} \\
& +464.335\left(\mathrm{U}_{\mathrm{LL}}\right)^{4}-650.677\left(\mathrm{U}_{\mathrm{LL}}\right)^{5}
\end{aligned}
$$

where $E_{e}$ is the effective elastic modulus, $B_{e}$ is the effective specimen thickness expressed as $B$ $-\left(B-B_{N}\right)^{2} / B$, and $W$ is specimen width.

Both rotation and modulus corrections are applied to the compliance data. The modulus correction $^{\mathrm{A}-2}$ is used to account for the uncertainties in testing, i.e., in the values of initial crack length determined by compliance and measured optically. The effective modulus $E_{M}$ is determined from

$$
E_{e}=\frac{1}{C_{o} B_{e}}\left(\frac{W+a_{o}}{W-a_{o}}\right)^{1 / 2} f\left(\frac{a_{o}}{W}\right)
$$

and

$$
\begin{aligned}
f\left(\frac{a_{o}}{W}\right)=2.163 & +12.219\left(\frac{a_{o}}{W}\right)-20.065\left(\frac{a_{o}}{W}\right)^{2}-0.9925\left(\frac{a_{o}}{W}\right)^{3} \\
& +20.609\left(\frac{a_{o}}{W}\right)^{4}-9.9314\left(\frac{a_{o}}{W}\right)^{5},
\end{aligned}
$$

where $C_{o}$ is initial compliance, $B_{e}$ is effective specimen thickness, and $a_{o}$ is initial physical crack size that has been measured optically.

To account for crack-opening displacement in CT specimens, the crack size should be corrected for rotation. ${ }^{A-3}$ The corrected compliance is calculated from 


$$
\theta=\operatorname{Sin}^{-1}\left[\left(\frac{d_{m}}{2}+D\right) /\left(D^{2}+R^{2}\right)^{1 / 2}\right]-\tan ^{-1}\left(\frac{D}{R}\right)
$$

and

$$
\mathrm{C}_{\mathrm{c}}=\mathrm{C}_{\mathrm{m}} /\left[\left(\frac{\mathrm{H}^{*}}{\mathrm{R}} \operatorname{Sin} \theta-\operatorname{Cos} \theta\right)\left(\frac{\mathrm{D}}{\mathrm{R}} \operatorname{Sin} \theta-\operatorname{Cos} \theta\right)\right],
$$

where $\mathrm{C}_{\mathrm{c}}$ and $\mathrm{C}_{\mathrm{m}}$ are the corrected and measured elastic compliance at the load line, $\mathrm{H}^{*}$ is the initial half span of load points, $R$ is the radius of rotation of the crack centerline $(=(W+a) / 2)$, a is the updated crack length, $D$ is one-half of the initial distance between the displacement points (i.e., one-half of the gage length), $\mathrm{d}_{\mathrm{m}}$ is the total measured load-line displacement, and $\theta$ is the angle of rotation of a rigid-body element about the unbroken midsection line.

The $\mathrm{J}$ value is calculated at any point on the load-vs.-load-line displacement record by means of the relationship

$$
\mathbf{J}=\mathbf{J}_{\mathrm{el}}+\mathbf{J}_{\mathrm{pl}},
$$

where $\mathrm{Jel}_{\mathrm{el}}$ is the elastic component of $\mathrm{J}$ and $\mathrm{J}_{\mathrm{pl}}$ is the plastic component of $\mathrm{J}$. For a CT specimen, at a point corresponding to the coordinates $\mathrm{P}_{\mathrm{i}}$ and $\delta_{\mathrm{i}}$ on the specimen load-vs.-load-line displacement record, $a_{i}$ is $\left(a_{0}+\Delta a_{i}\right)$, and the deformation $\mathrm{J}$ is given by

$$
\mathbf{J}_{\mathrm{d}(\mathrm{i})}=\frac{\left(\mathrm{K}_{\mathrm{i}}\right)^{2}\left(1-v^{2}\right)}{\mathrm{E}_{\mathrm{e}}}+\mathbf{J}_{\mathrm{pl}(\mathrm{i})}
$$

where, from ASTM method E 399,

$$
\mathrm{K}_{(\mathrm{i})}=\left[\frac{\mathrm{P}_{\mathrm{i}}}{\left(\mathrm{BB}_{\mathrm{N}} \mathrm{W}_{\mathrm{e}}\right)^{1 / 2}}\right] \mathrm{f}\left(\frac{\mathrm{a}_{\mathrm{i}}}{\mathrm{W}}\right)
$$

with

$$
\begin{gathered}
f\left(\frac{a_{i}}{W}\right)=\left[2+\left(\frac{a_{i}}{W}\right)\right]\left[0.886+4.64\left(\frac{a_{i}}{W}\right)-13.32\left(\frac{a_{i}}{W}\right)^{2}+14.72\left(\frac{a_{i}}{W}\right)^{3}\right. \\
\left.-5.6\left(\frac{a_{i}}{W}\right)^{4}\right] /\left[1-\left(\frac{a_{i}}{W}\right)\right]^{3 / 2}
\end{gathered}
$$

and

$$
\mathbf{J}_{\mathrm{pl}(\mathrm{i})}=\left[\mathbf{J}_{\mathrm{pl}(\mathrm{i}-1)}+\left(\frac{\eta_{\mathrm{i}}}{\mathrm{b}_{\mathrm{i}}}\right) \frac{\mathrm{A}_{\mathrm{pl}(\mathrm{i})}-\mathrm{A}_{\mathrm{pl}(\mathrm{i}-1)}}{\mathrm{B}_{\mathrm{N}}}\right]\left[1-\left(\frac{\gamma_{\mathrm{i}}}{\mathrm{b}_{\mathrm{i}}}\right)\left(\mathrm{a}_{\mathrm{i}}-\mathrm{a}_{\mathrm{i}-1}\right)\right],
$$


where $v$ is Poisson's ratio, $b$ is the uncracked ligament, $A_{p l}$ is the plastic component of the area under the load-vs.-load-line displacement record, $\eta$ is a factor that accounts for the tensile component of the load as given by

$$
\eta_{\mathrm{i}}=2+0.522 \mathrm{~b}_{\mathrm{i}} / \mathrm{W}
$$

and $\gamma$, is a factor that accounts for limited crack growth as given by

$$
\gamma_{\mathrm{i}}=1+0.76 \mathrm{~b}_{\mathrm{i}} / \mathrm{W}
$$

Modified $\mathrm{J}$ values $\left(\mathrm{J}_{\mathrm{M}}\right)$ are calculated from the relationship (from Ref. A-4)

$$
\mathbf{J}_{\mathrm{M}(\mathrm{i})}=\mathbf{J}_{\mathrm{d}(\mathrm{i})}+\Delta \mathbf{J}_{\mathrm{i}}
$$

where

$$
\Delta \mathbf{J}_{\mathrm{i}}=\Delta \mathbf{J}_{\mathrm{i}-1}+\left(\frac{\gamma_{\mathrm{i}}}{\mathrm{b}_{\mathrm{i}}}\right) \mathbf{J}_{\mathrm{pl}(\mathrm{i})}\left(\mathrm{a}_{\mathrm{i}}-\mathrm{a}_{\mathrm{i}-1}\right)
$$

According to ASTM Specification E 1152-87, the $J_{D}-R$ curves are valid only for crack growth up to $10 \%$ of the initial uncracked ligament. Also, they show a dependence on specimen size. The $J_{M}-R$ curves have been demonstrated to be independent of specimen size and yield valid results for larger crack growth.

\section{Data Qualification}

The various validity criteria specified in ASTM Specification E 813-85 for $J_{I C}$ and in ASTM Specification E 1152-87 for J-R curves were used to qualify the results from each test. The various criteria include maximum values of crack extension and J-integrals; limits for initial uncracked ligaments, effective elastic modulus, and optically measured physical crack lengths; and spacing of $J-\Delta$ a data points. The $\omega$ criterion (from Ref. A-5) was also used to ensure that a region of $\mathrm{J}$ dominance exists. For the present investigation, all of the welds yielded invalid test results; in most cases because of the shape of the final crack front. In some cases, specimen thickness was inadequate because of the relatively high toughness of the material. The $J_{\max }$ limit for the J-vs. $-\Delta$ a data was ignored in most tests to obtain a good power-law fit of the test data.

\section{Appendix References}

A-1. A. L. Hiser, F. J. Loss, and B. H. Menke, J-R Curve Characterization of Irradiated Low Upper Shelf Welds, NUREG/CR-3506, MEA-2028, Materials Engineering Associates, Inc., Lanham, MD (April 1984).

A-2. A. Saxena and S. J. Hudak, Jr., "Review and Extention of Compliance Information for Common Crack Growth Specimen," Int. J. Fracture, 5, 453-468 (1978).

A-3. F. J. Loss, B. H. Menke, and R. A. Gray, Jr., "Development of J-R Curve Procedures," in NRL-EPRI Research Program (RP 886-2), Evaluation and Prediction of Neutron 
Embrittlement in Reactor Pressure Vessel Materials Annual Progress Report for FY 1978, J. R. Hawthorn, ed., NRL Report 8327, Naval Research Laboratory, Annapolis, MD (Aug. 1979).

A-4. H. A. Ernst, "Material Resistance and Instability Beyond J-Controlled Crack Growth," Elastic-Plastic Fracture: Second Symp., Vol. I: Inelastic Crack Analysis, ASTM STP 803, American Society for Testing and Materials, Philadelphia (1983).

A-5. J. W. Hutchinson and P. C. Paris, "The Theory of Stability Analysis of J-Controlled Crack Growth," Elastic Plastic Fracture, ASTM STP 668, American Society for Testing and Materials, Philadelphia, pp. 37-64 (1983). 
Table A-1. Test data for specimen PWCE-02

\begin{tabular}{|c|c|c|c|c|c|}
\hline $\begin{array}{l}\text { Test Nun } \\
\text { Material } \\
\text { Aging Te } \\
\text { Thicknes } \\
\text { Width }\end{array}$ & $\begin{array}{l}\text { oer } \\
\text { ype } \\
\text { ip }\end{array}$ & $\begin{array}{l}\text { Metal } \\
\text { ed } \\
\mathrm{mm} \\
\mathrm{mm}\end{array}$ & $\begin{array}{l}\text { Test } \\
\text { Heat } \\
\text { Aging } \\
\text { Net T } \\
\text { Flow }\end{array}$ & s & $0 \mathrm{~mm}$ \\
\hline $\begin{array}{c}\text { Unload } \\
\text { Number }\end{array}$ & $\begin{array}{c}J_{d} \\
\left(k J / m^{2}\right)\end{array}$ & $\begin{array}{c}J_{m} \\
\left(k J / m^{2}\right)\end{array}$ & $\begin{array}{c}\Delta \mathrm{a} \\
(\mathrm{m} \mathrm{m})\end{array}$ & $\begin{array}{l}\text { Load } \\
(\mathrm{kN})\end{array}$ & $\begin{array}{c}\text { Deflection } \\
(\mathrm{m} \mathrm{m})\end{array}$ \\
\hline 1 & 15.20 & 15.20 & 0.0000 & 23.443 & 0.250 \\
\hline 2 & 52.28 & 52.31 & 0.0280 & $\begin{array}{l}36.946 \\
\text { (n) }\end{array}$ & 0.502 \\
\hline 3 & 102.22 & 102.54 & 0.1172 & 43.820 & 0.755 \\
\hline 4 & 157.48 & 158.72 & 0.2672 & 47.057 & 1.004 \\
\hline 5 & 227.48 & 228.42 & 0.2367 & 48.949 & 1.305 \\
\hline 6 & 301.95 & 304.11 & 0.3225 & 50.353 & 1.606 \\
\hline 7 & 377.68 & 380.14 & 0.3385 & 51.045 & 1.911 \\
\hline 8 & 454.79 & 456.23 & 0.2947 & 51.581 & 2.210 \\
\hline 9 & 529.58 & 536.70 & 0.4997 & 52.029 & 2.509 \\
\hline 10 & 603.85 & 613.98 & 0.5935 & 52.481 & 2.811 \\
\hline 11 & 680.85 & 695.23 & 0.7086 & 52.830 & 3.116 \\
\hline 12 & 755.23 & 772.60 & 0.7808 & 52.807 & 3.408 \\
\hline 13 & 833.02 & 853.72 & 0.8529 & 52.943 & 3.710 \\
\hline 14 & 907.13 & 935.76 & 1.0088 & 52.928 & 4.010 \\
\hline 15 & 981.59 & 1016.74 & 1.1262 & 52.940 & 4.310 \\
\hline 16 & 1056.79 & 1098.06 & 1.2275 & 52.844 & 4.610 \\
\hline 17 & 1128.50 & 1180.43 & 1.3912 & 52.693 & 4.908 \\
\hline 18 & 1201.74 & 1262.91 & 1.5234 & 52.370 & 5.212 \\
\hline 19 & 1273.41 & 1346.72 & 1.6857 & 52.211 & 5.517 \\
\hline 20 & 1352.00 & 1423.84 & 1.6673 & 52.127 & 5.809 \\
\hline 21 & 1431.84 & 1540.61 & 2.0977 & 51.770 & 6.208 \\
\hline 22 & 1536.75 & 1642.96 & 2.0701 & 51.538 & 6.609 \\
\hline 23 & 1628.47 & 1758.04 & 2.3059 & 51.313 & 7.008 \\
\hline 24 & 1720.16 & 1867.79 & 2.4772 & 50.992 & 7.411 \\
\hline 25 & 1805.54 & 1978.68 & 2.7049 & 50.287 & 7.809 \\
\hline 26 & 1912.16 & 2116.36 & 2.9638 & 49.847 & 8.307 \\
\hline 27 & 2013.56 & 2254.97 & 3.2545 & 49.355 & 8.808 \\
\hline 28 & 2134.33 & 2389.33 & 3.3538 & 48.396 & 9.309 \\
\hline 29 & 2239.91 & 2528.49 & 3.5853 & 47.767 & 9.807 \\
\hline 30 & 2341.12 & 2664.76 & 3.8140 & 47.301 & 10.307 \\
\hline 31 & 2422.73 & 2804.41 & 4.1745 & 46.812 & 10.812 \\
\hline 32 & 2553.13 & 2963.93 & 4.3445 & 45.997 & 11.411 \\
\hline 33 & 2664.57 & 3129.43 & 4.6428 & 45.451 & 12.008 \\
\hline 34 & 2792.24 & 3289.24 & 4.8103 & 44.687 & 12.607 \\
\hline $\begin{array}{l}04 \\
35\end{array}$ & 2897.83 & 3454.39 & $\begin{array}{l}4.01055 \\
5.1055\end{array}$ & 43.776 & 13.209 \\
\hline 36 & 2992.22 & 3614.99 & 5.4187 & 43.160 & 13.808 \\
\hline 37 & 3106.00 & 3803.53 & 5.7538 & 42.271 & 14.511 \\
\hline 38 & 3218.54 & 3988.74 & 6.0633 & 41.357 & 15.208 \\
\hline
\end{tabular}


Table A-2. Deformation JIC and J-R curve results for specimen PWCE-02

\begin{tabular}{|c|c|c|c|}
\hline $\begin{array}{l}\text { Test Number } \\
\text { Material Type }\end{array}$ & $\begin{array}{l}: 0125 \\
\text { : Weld Metal }\end{array}$ & $\begin{array}{l}\text { Test Temp } \\
\text { Heat Number }\end{array}$ & : $25^{\circ} \mathrm{C}$ \\
\hline Aging Temp & : Unaged & Aging Time & $:-$ \\
\hline Thickness & : $25.36 \mathrm{~mm}$ & Net Thickness & : $20.18 \mathrm{~mm}$ \\
\hline Width & : $50.78 \mathrm{~mm}$ & Flow Stress & : $534.00 \mathrm{MPa}$ \\
\hline Modulus E & $: 195.06 \mathrm{GPa}$ & (Effective) & \\
\hline Modulus E & $: 193.10 \mathrm{GPa}$ & (Nominal) & \\
\hline Init. Crack & : $28.2063 \mathrm{~mm}$ & Init. a/ w & : 0.5554 (Measured) \\
\hline Final Crack & : $35.0094 \mathrm{~mm}$ & Final a/w & : 0.6894 (Measured) \\
\hline Final Crack & : $34.2695 \mathrm{~mm}$ & Final a/w & 0.6748 (Compliance) \\
\hline $\begin{array}{l}\text { Linear Fit } \\
\text { Intercept B } \\
\text { Fit Coeff. R } \\
J_{I C} \\
\Delta \text { a }\left(J_{I C}\right) \\
\text { T average }\end{array}$ & $\begin{array}{l}\mathbf{J}=\mathbf{B}+\mathbf{M}(\mathbf{\Delta} \mathbf{a}) \\
: 283.992 \mathrm{~kJ} / \mathrm{m}^{2} \\
: 0.9900 \\
: 394.3 \mathrm{~kJ} / \mathrm{m}^{2} \\
: 0.185 \mathrm{~mm} \\
: 408.7\end{array}$ & $\begin{array}{l}\text { Slope } M \\
(14 \text { Data Points) } \\
\left(2251.4 \text { in.-lb/in. }{ }^{2}\right) \\
(0.0073 \text { in. }) \\
\left(J_{I C} \text { at } 0.15\right)\end{array}$ & : $597.47 \mathrm{~kJ} / \mathrm{m}^{3}$ \\
\hline $\begin{array}{l}\text { Power-Law Fit } \\
\text { Coeff. C } \\
\text { Fit Coeff. R } \\
\mathrm{J}_{\mathrm{IC}}(0.20) \\
\Delta \mathrm{a}\left(\mathrm{J}_{\mathrm{IC}}\right) \\
\mathrm{T} \text { average } \\
\mathrm{J}_{\mathrm{IC}}(0.15) \\
\Delta \mathrm{a}\left(\mathrm{J}_{\mathrm{IC}}\right) \\
\mathrm{T} \text { average } \\
\mathrm{K}_{\mathrm{j} \mathrm{c}}\end{array}$ & $\begin{array}{l}\mathbf{J}=\mathbf{C}(\Delta \mathbf{a})^{\mathbf{n}} \\
: 893.25 \mathrm{~kJ} / \mathrm{m}^{2} \\
: 0.9962 \\
: 482.4 \mathrm{~kJ} / \mathrm{m}^{2} \\
: 0.426 \mathrm{~mm} \\
: 414.3 \\
: 413.0 \mathrm{~kJ} / \mathrm{m}^{2} \\
: 0.343 \mathrm{~mm} \\
: 419.5 \\
: 559.4 \mathrm{MPa}-\mathrm{m}^{0.5}\end{array}$ & $\begin{array}{l}\text { Exponent } \mathrm{n} \\
(14 \text { Data Points) } \\
\left(2754.9 \text { in.-lb/in. }{ }^{2}\right) \\
(0.0168 \text { in. }) \\
\left(J_{I C} \text { at } 0.20\right) \\
\left(2358.4 \text { in.-lb/in. }{ }^{2}\right) \\
(0.0135 \text { in. }) \\
\left(J_{I C} \text { at } 0.15\right)\end{array}$ & 0.7216 \\
\hline $\begin{array}{l}J_{I C} \text { Validity \& Data } \\
J_{\text {max allowed }} \\
\text { Data Limit } \\
\Delta \text { a (max) allowed } \\
\text { Data Limit } \\
\text { Data Points } \\
\text { Data Point Spacing } \\
B_{\text {net or } b_{O} \text { size }} \\
\text { dJ/da at JIC) } \\
a_{\circ} \text { Measurement } \\
a_{0} \text { Measurement } \\
\text { af Measurement } \\
\text { Crack size estimate } \\
\text { E Effective } \\
J_{I C} \text { Estimate }\end{array}$ & $\begin{array}{l}\text { Qualification (E 813- } \\
: 803.70 \mathrm{~kJ} / \mathrm{m}^{2} \\
: \text { Jmax Ignored } \\
: 2.251 \mathrm{~mm} \\
: 1.5 \text { Exclusion line } \\
: \text { Zone A = 5 } \\
: \text { OK } \\
: \text { OK } \\
: \text { OK } \\
: 9 \text { Outside Limit } \\
: 1 \text { Outside Limit } \\
: \text { Near-surface } \\
: \text { Inadequate } \\
: \text { OK } \\
: \text { Invalid }\end{array}$ & $\begin{array}{l}\text { 5) } \\
\left(J_{\max }=b_{o} \sigma_{f} / 15\right) \\
\text { (at } 1.5 \text { exclusion line) } \\
\text { Zone } B=4\end{array}$ & \\
\hline $\begin{array}{l}\text { J-R curve Validity } \\
\text { Jmax allowed } \\
\Delta a(\max ) \text { allowed } \\
\Delta a(\max ) \text { allowed } \\
\text { Data Points } \\
\text { Data Point Spacing } \\
\text { J-R Curve Data }\end{array}$ & $\begin{array}{l}\text { \& Data Qualification } \\
: 538.89 \mathrm{~kJ} / \mathrm{m}^{2} \\
: 2.258 \mathrm{~mm} \\
: 6.405 \mathrm{~mm} \\
: \text { Zone A }=20 \\
: \text { Inadequate } \\
: \text { Invalid }\end{array}$ & $\begin{array}{l}\text { 1152-86) } \\
\left(\mathrm{J}_{\max }=\mathrm{B}_{\text {net }} \sigma_{f} / 20\right) \\
\left(\Delta \mathrm{a}=0.1 \mathrm{~b}_{\mathrm{o}}\right) \\
(\omega=5) \\
\text { Zone } \mathrm{B}=2\end{array}$ & \\
\hline
\end{tabular}


Table A-3. Modified JIC and $\mathrm{J}-R$ curve results for specimen PWCE-02

\begin{tabular}{|c|c|c|c|}
\hline $\begin{array}{l}\text { Linear Fit } \\
\text { Intercept B } \\
\text { Fit Coeff. R } \\
\mathrm{J}_{\mathrm{IC}} \\
\Delta \mathrm{a}\left(\mathrm{J}_{\mathrm{IC}}\right) \\
\mathrm{T} \text { average }\end{array}$ & $\begin{array}{l}\mathbf{J}=\mathbf{B}+\mathbf{M}(\Delta \mathbf{a}) \\
: 255.520 \mathrm{~kJ} / \mathrm{m}^{2} \\
: 0.9944 \\
: 369.1 \mathrm{~kJ} / \mathrm{m}^{2} \\
: 0.173 \mathrm{~mm} \\
: 449.7\end{array}$ & $\begin{array}{l}\text { Slope } M \\
(15 \text { Data Points) } \\
\left(2107.8 \text { in.-lb/in. }{ }^{2}\right) \\
(0.0068 \text { in. }) \\
\left(J_{I C} \text { at } 0.15\right)\end{array}$ & : $657.42 \mathrm{~kJ} / \mathrm{m}^{3}$ \\
\hline $\begin{array}{l}\text { Power-Law Fit } \\
\text { Coeff. C } \\
\text { Fit Coeff. R } \\
\mathrm{J}_{\mathrm{IC}}(0.20) \\
\Delta \mathrm{a}\left(\mathrm{J}_{\mathrm{IC}}\right) \\
\mathrm{T} \text { average } \\
\mathrm{J}_{\mathrm{IC}}(0.15) \\
\Delta \mathrm{a}\left(\mathrm{J}_{\mathrm{IC}}\right) \\
\mathrm{T}_{\text {average }} \\
\mathrm{K}_{\mathrm{j}} \mathrm{c}\end{array}$ & $\begin{array}{l}\mathbf{J}=\mathbf{C}(\Delta \mathbf{a})^{\mathbf{n}} \\
: 924.64 \mathrm{~kJ} / \mathrm{m}^{2} \\
: 0.9977 \\
: 481.9 \mathrm{~kJ} / \mathrm{m}^{2} \\
: 0.426 \mathrm{~mm} \\
: \begin{array}{l} \\
:\end{array} \\
: 406.7 \mathrm{~kJ} / \mathrm{m}^{2} \\
: 0.340 \mathrm{~mm} \\
: 459.6 \\
: 585.5 \mathrm{MPa}-\mathrm{m}^{0.5}\end{array}$ & $\begin{array}{l}\text { Exponent } n \\
(15 \text { Data Points) } \\
\left(2751.5 \text { in.-lb/in. }{ }^{2}\right) \\
(0.0168 \text { in.) } \\
\left(J_{I C} \text { at } 0.20\right) \\
\left(2319.0 \text { in.-lb/in. }{ }^{2}\right) \\
(0.0134 \text { in. }) \\
\left(J_{I C} \text { at } 0.15\right)\end{array}$ & $: 0.7629$ \\
\hline
\end{tabular}

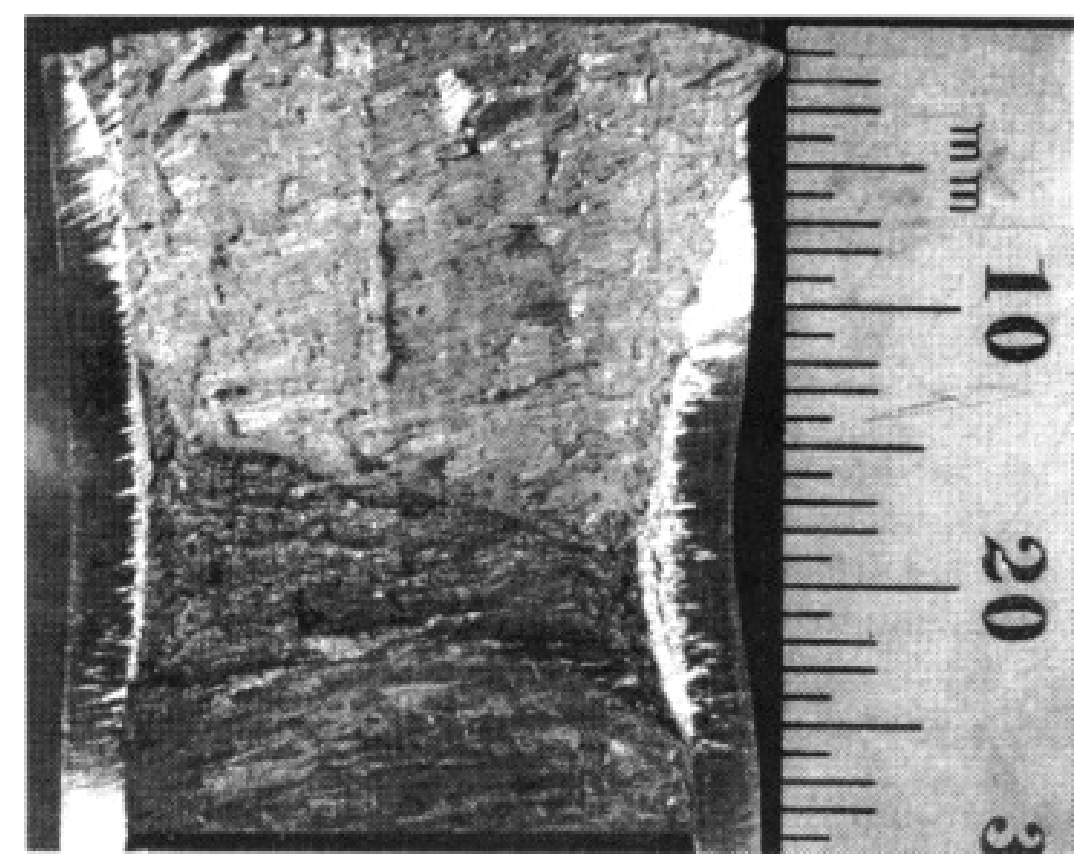

Figure A-1. Fracture surface of unaged weld metal PWCE tested at $25^{\circ} \mathrm{C}$ 


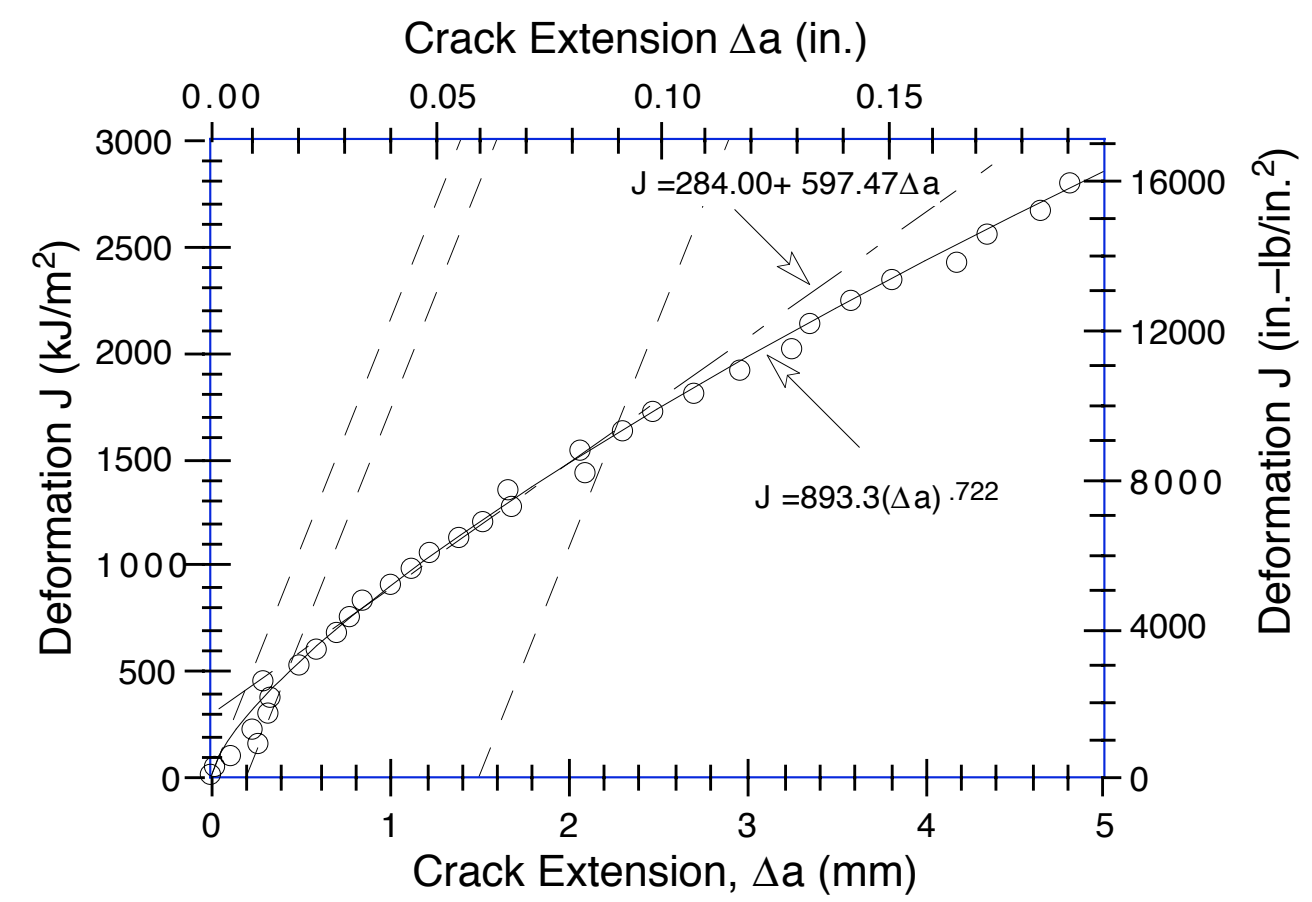

Figure A-2. Deformation J-R curve for unaged weld metal specimen PWCE-02 tested at $25^{\circ} \mathrm{C}$. Blunting, 0.2- $\mathrm{mm}$ offset, and 1.5- $\mathrm{mm}$ offset lines are shown as dashed lines.

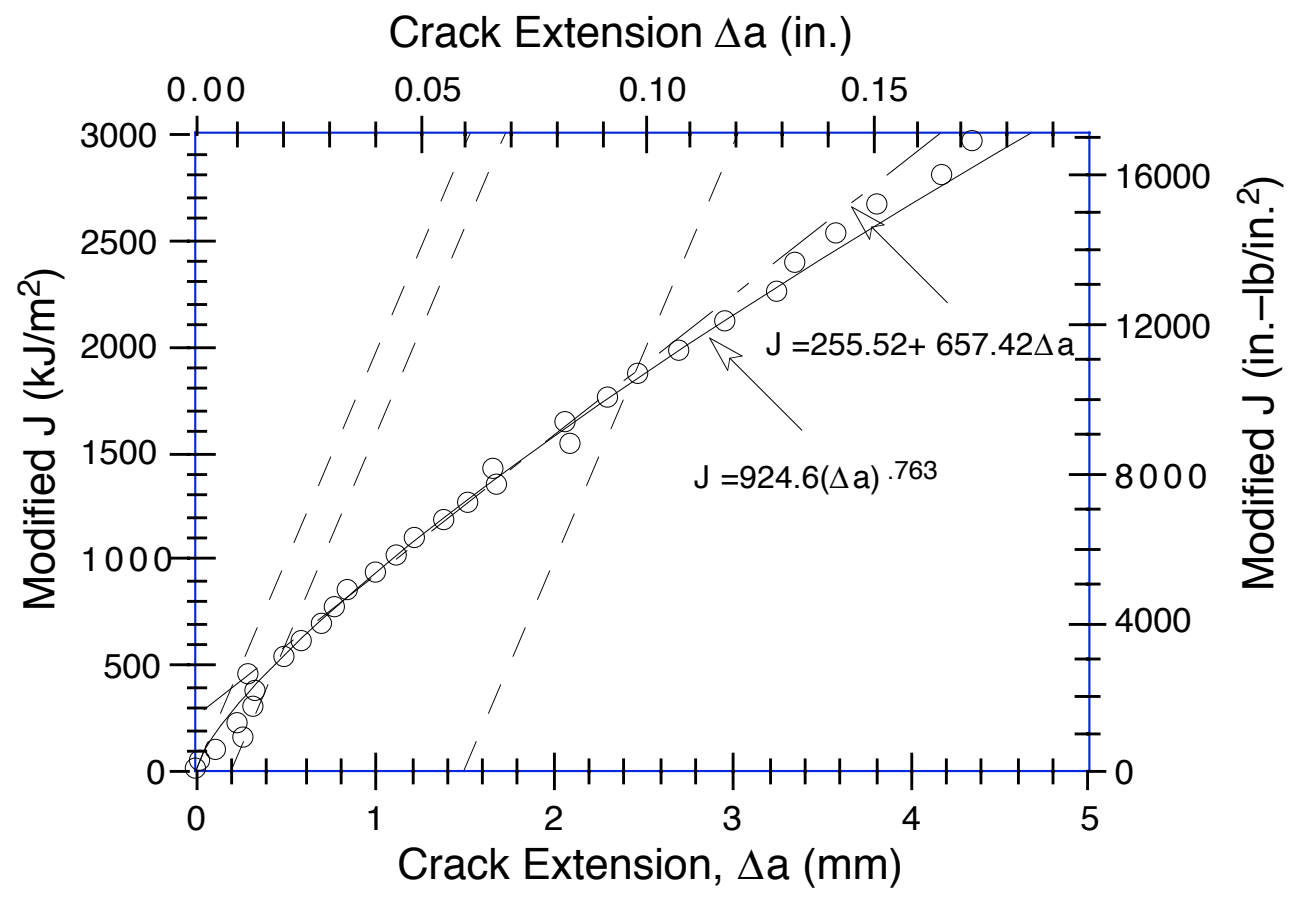

Figure A-3. Modified $J-R$ curve for unaged weld metal specimen PWCE-02 tested at $25^{\circ} \mathrm{C}$. Blunting, $0.2-\mathrm{mm}$ offset, and $1.5-\mathrm{mm}$ offset lines are shown as dashed lines. 
Table A-4. Test data for specimen PWCE-04

$\begin{array}{llll}\text { Test Number } & : 0129 & \text { Test Temp } & : 25^{\circ} \mathrm{C} \\ \text { Material Type } & : \text { Weld Metal } & \text { Heat Number } & : \text { PWCE } \\ \text { Aging Temp } & : 400^{\circ} \mathrm{C} & \text { Aging Time } & : 10,000 \mathrm{~h} \\ \text { Thickness } & : 25.37 \mathrm{~mm} & \text { Net Thickness } & : 20.29 \mathrm{~mm} \\ \text { Width } & : 50.80 \mathrm{~mm} & \text { Flow Stress } & : 538.00 \mathrm{MPa}\end{array}$

\begin{tabular}{|c|c|c|c|c|c|}
\hline $\begin{array}{l}\text { Unload } \\
\text { Number }\end{array}$ & $\begin{array}{c}J_{d} \\
\left(k J / m^{2}\right)\end{array}$ & $\begin{array}{c}J_{m} \\
\left(k J / m^{2}\right)\end{array}$ & $\begin{array}{c}\Delta \mathrm{a} \\
(\mathrm{m} \mathrm{m}) \\
\end{array}$ & $\begin{array}{l}\text { Load } \\
(\mathrm{kN})\end{array}$ & $\begin{array}{c}\text { Deflection } \\
(\mathrm{m} \mathrm{m})\end{array}$ \\
\hline 1 & 16.29 & 16.28 & -0.1303 & 26.132 & 0.251 \\
\hline 2 & 58.75 & 59.01 & 0.1101 & 42.335 & 0.502 \\
\hline 3 & 100.62 & 100.80 & 0.0805 & 48.905 & 0.703 \\
\hline 4 & 150.27 & 150.79 & 0.1433 & 51.989 & 0.905 \\
\hline 5 & 201.40 & 202.58 & 0.2264 & 53.926 & 1.106 \\
\hline 6 & 253.46 & 256.21 & 0.3695 & 55.297 & 1.306 \\
\hline 7 & 306.00 & 308.03 & 0.3180 & 56.009 & 1.507 \\
\hline 8 & 362.41 & 364.26 & 0.3077 & 56.437 & 1.708 \\
\hline 9 & 418.59 & 422.46 & 0.4064 & 57.337 & 1.911 \\
\hline 10 & 471.26 & 477.36 & 0.5011 & 57.678 & 2.107 \\
\hline 11 & 524.22 & 535.12 & 0.6809 & 57.882 & 2.307 \\
\hline 12 & 582.23 & 588.55 & 0.5289 & 58.212 & 2.510 \\
\hline 13 & 642.26 & 649.10 & 0.5442 & 58.329 & 2.710 \\
\hline 14 & 700.26 & 705.55 & 0.5023 & 58.455 & 2.908 \\
\hline 15 & 754.28 & 768.16 & 0.7150 & 58.539 & 3.112 \\
\hline 16 & 806.09 & 823.63 & 0.7990 & 58.773 & 3.311 \\
\hline 17 & 860.16 & 880.65 & 0.8620 & 58.739 & 3.508 \\
\hline 18 & 913.74 & 940.68 & 0.9902 & 58.583 & 3.710 \\
\hline 19 & 963.16 & 999.13 & 1.1594 & 58.668 & 3.908 \\
\hline 20 & 1014.99 & 1058.42 & 1.2910 & 58.897 & 4.111 \\
\hline 21 & 1069.51 & 1115.39 & 1.3317 & 58.766 & 4.308 \\
\hline 22 & 1128.93 & 1175.39 & 1.3408 & 58.956 & 4.510 \\
\hline 23 & 1190.65 & 1254.22 & 1.5925 & 58.914 & 4.759 \\
\hline 24 & 1267.00 & 1322.92 & 1.4871 & 58.483 & 5.009 \\
\hline 25 & 1328.22 & 1405.16 & 1.7607 & 58.379 & 5.260 \\
\hline 26 & 1385.09 & 1478.41 & 1.9630 & 57.978 & 5.510 \\
\hline 27 & 1459.29 & 1549.27 & 1.9239 & 57.701 & 5.761 \\
\hline 28 & 1510.18 & 1630.78 & 2.2657 & 57.500 & 6.010 \\
\hline 29 & 1563.64 & 1701.56 & 2.4509 & 57.153 & 6.258 \\
\hline 30 & 1640.00 & 1779.10 & 2.4630 & 56.718 & 6.525 \\
\hline 31 & 1701.40 & 1852.14 & 2.5761 & 56.527 & 6.759 \\
\hline 32 & 1751.71 & 1929.25 & 2.8267 & 55.871 & 7.008 \\
\hline 33 & 1811.93 & 2001.16 & 2.9317 & 55.320 & 7.259 \\
\hline 34 & 1865.97 & 2078.21 & 3.1307 & 54.797 & 7.511 \\
\hline 35 & 1919.87 & 2151.04 & 3.2885 & 54.298 & 7.759 \\
\hline 36 & 1984.76 & 2223.78 & 3.3516 & 53.726 & 8.010 \\
\hline 37 & 2029.35 & 2318.46 & 3.7392 & 53.166 & 8.309 \\
\hline 38 & 2091.51 & 2402.24 & 3.9002 & 52.563 & 8.611 \\
\hline 39 & 2143.87 & 2492.01 & 4.1688 & 51.562 & 8.908 \\
\hline 40 & 2200.24 & 2578.59 & 4.3782 & 50.911 & 9.209 \\
\hline 41 & 2254.35 & 2666.79 & 4.6063 & 50.170 & 9.510 \\
\hline 42 & 2305.78 & 2753.14 & 4.8323 & 49.266 & 9.809 \\
\hline 43 & 2354.50 & 2839.71 & 5.0698 & 48.875 & 10.108 \\
\hline 44 & 2440.92 & 2954.13 & 5.2376 & 48.005 & 10.508 \\
\hline 45 & 2505.67 & 3073.20 & 5.5504 & 47.293 & 10.909 \\
\hline 46 & 2570.63 & 3185.61 & 5.8132 & 46.219 & 11.308 \\
\hline 47 & 2629.74 & 3299.21 & 6.1042 & 45.356 & 11.707 \\
\hline 48 & 2685.53 & 3411.48 & 6.3951 & 44.138 & 12.107 \\
\hline 49 & 2745.00 & 3522.81 & 6.6529 & 43.109 & 12.510 \\
\hline 50 & 2810.56 & 3631.55 & 6.8601 & 41.988 & 12.909 \\
\hline 51 & 2851.33 & 3743.30 & 7.1901 & 40.930 & 13.307 \\
\hline 52 & 2896.23 & 3878.73 & 7.5957 & 39.323 & 13.806 \\
\hline 53 & 2942.63 & 4008.44 & 7.9557 & 37.910 & 14.306 \\
\hline 54 & 2967.49 & 4139.43 & 8.3994 & 36.226 & 14.808 \\
\hline 55 & 3015.03 & 4261.21 & 8.6994 & 35.079 & 15.307 \\
\hline
\end{tabular}


Table A-5. Deformation JIC and J-R curve results for specimen PWCE-04

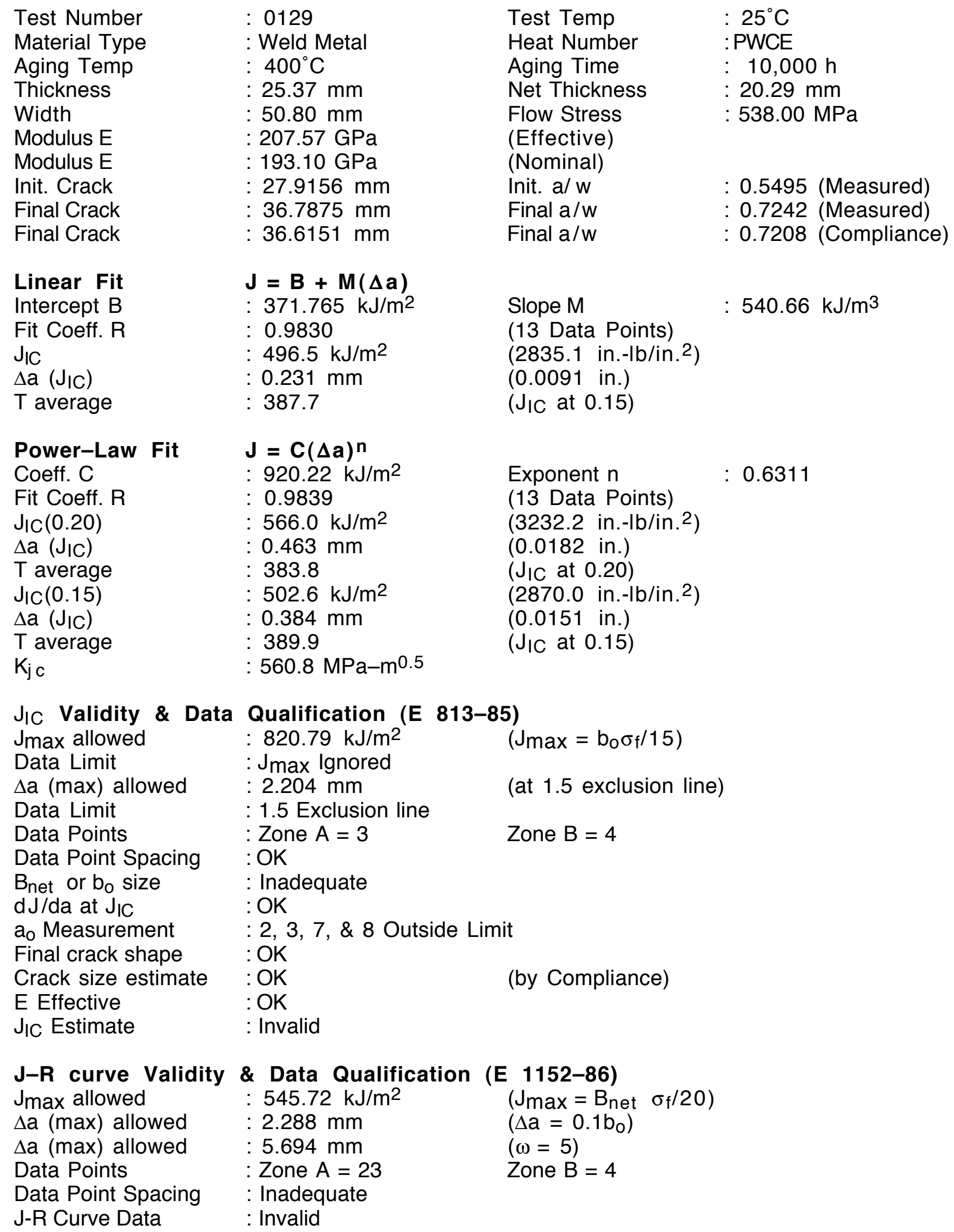


Table A-6. Modified JIC and $\mathrm{J}-R$ curve results for specimen PWCE-04

\begin{tabular}{|c|c|c|c|}
\hline $\begin{array}{l}\text { Linear Fit } \\
\text { Intercept B } \\
\text { Fit Coeff. R } \\
\mathrm{J}_{\mathrm{IC}} \\
\Delta \mathrm{a}\left(\mathrm{J}_{\mathrm{IC}}\right) \\
\mathrm{T} \text { average }\end{array}$ & $\begin{array}{l}\mathbf{J}=\mathbf{B}+\mathbf{M}(\mathbf{\Delta} \mathbf{a}) \\
: 336.028 \mathrm{~kJ} / \mathrm{m}^{2} \\
: 0.9862 \\
: 467.2 \mathrm{~kJ} / \mathrm{m}^{2} \\
: 0.217 \mathrm{~mm} \\
: 433.3\end{array}$ & $\begin{array}{l}\text { Slope M } \\
\text { (13 Data Points) } \\
\left(2667.9 \text { in.-lb/in. }{ }^{2}\right) \\
(0.0085 \text { in.) } \\
\left(J_{I C} \text { at } 0.15\right)\end{array}$ & $604.26 \mathrm{~kJ} / \mathrm{m}^{3}$ \\
\hline $\begin{array}{l}\text { Power-Law Fit } \\
\text { Coeff. C } \\
\text { Fit Coeff. R } \\
\mathrm{J}_{\mathrm{IC}}(0.20) \\
\Delta \mathrm{a}\left(\mathrm{J}_{\mathrm{IC}}\right) \\
\mathrm{T} \text { average } \\
\mathrm{J}_{\mathrm{IC}}(0.15) \\
\Delta \mathrm{a}\left(\mathrm{J}_{\mathrm{IC}}\right) \\
T \text { average } \\
\mathrm{K}_{\mathrm{j}} \mathrm{C}\end{array}$ & $\begin{array}{l}\mathbf{J}=\mathbf{C}(\Delta \mathbf{a}) \mathbf{n} \\
: 948.65 \mathrm{~kJ} / \mathrm{m}^{2} \\
: 0.9865 \\
: 562.6 \mathrm{~kJ} / \mathrm{m}^{2} \\
: 0.461 \mathrm{~mm} \\
: 424.6 \\
: 492.4 \mathrm{~kJ} / \mathrm{m}^{2} \\
: 0.379 \mathrm{~mm} \\
: 430.6 \\
: 585.0 \mathrm{MPa}-\mathrm{m}^{0.5}\end{array}$ & $\begin{array}{l}\text { Exponent } n \\
(13 \text { Data Points) } \\
\left(3212.3 \text { in.-lb/in. }{ }^{2}\right) \\
(0.0182 \text { in.) } \\
\left(\mathrm{J}_{I C} \text { at } 0.20\right) \\
\left(2811.4 \text { in.-lb/in. }{ }^{2}\right) \\
(0.0149 \text { in.) } \\
\left(J_{I C} \text { at } 0.15\right)\end{array}$ & 0.6756 \\
\hline
\end{tabular}

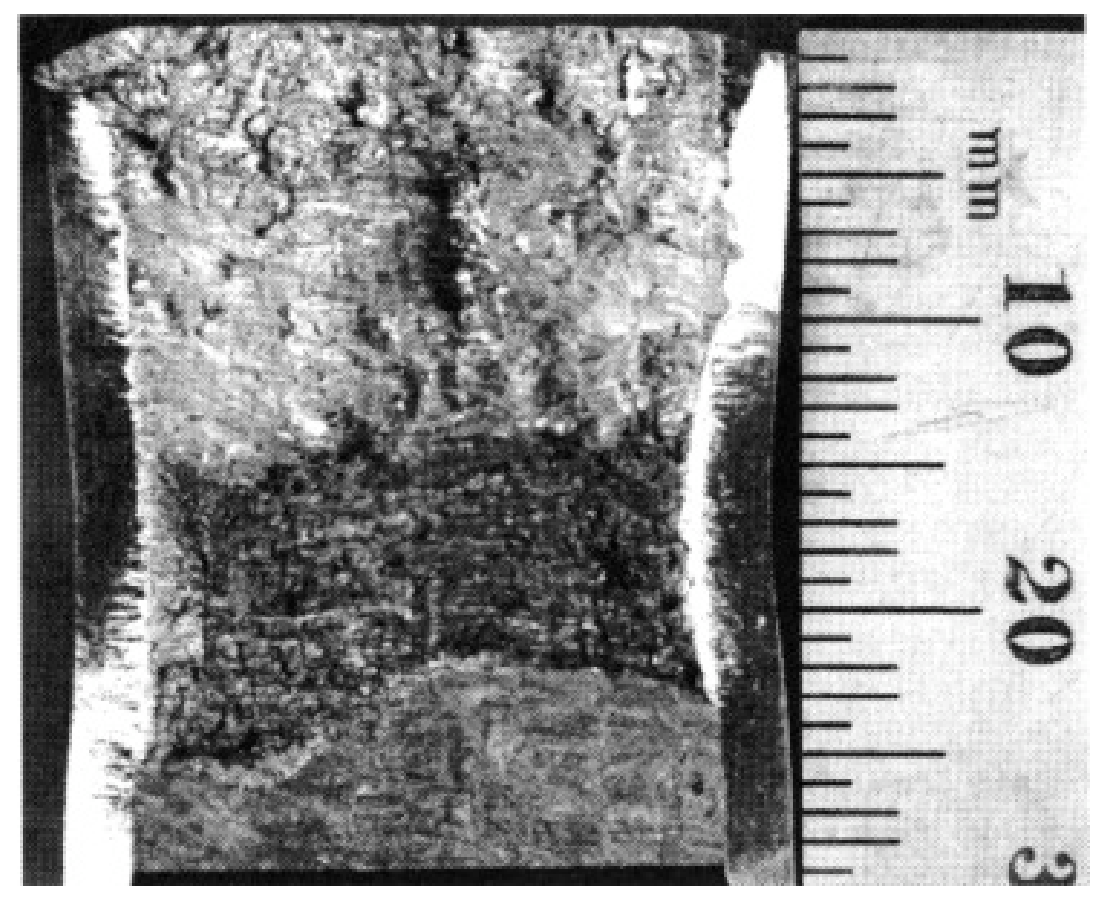

Figure A-4. Fracture surface of aged weld metal PWCE tested at $25^{\circ} \mathrm{C}$ 


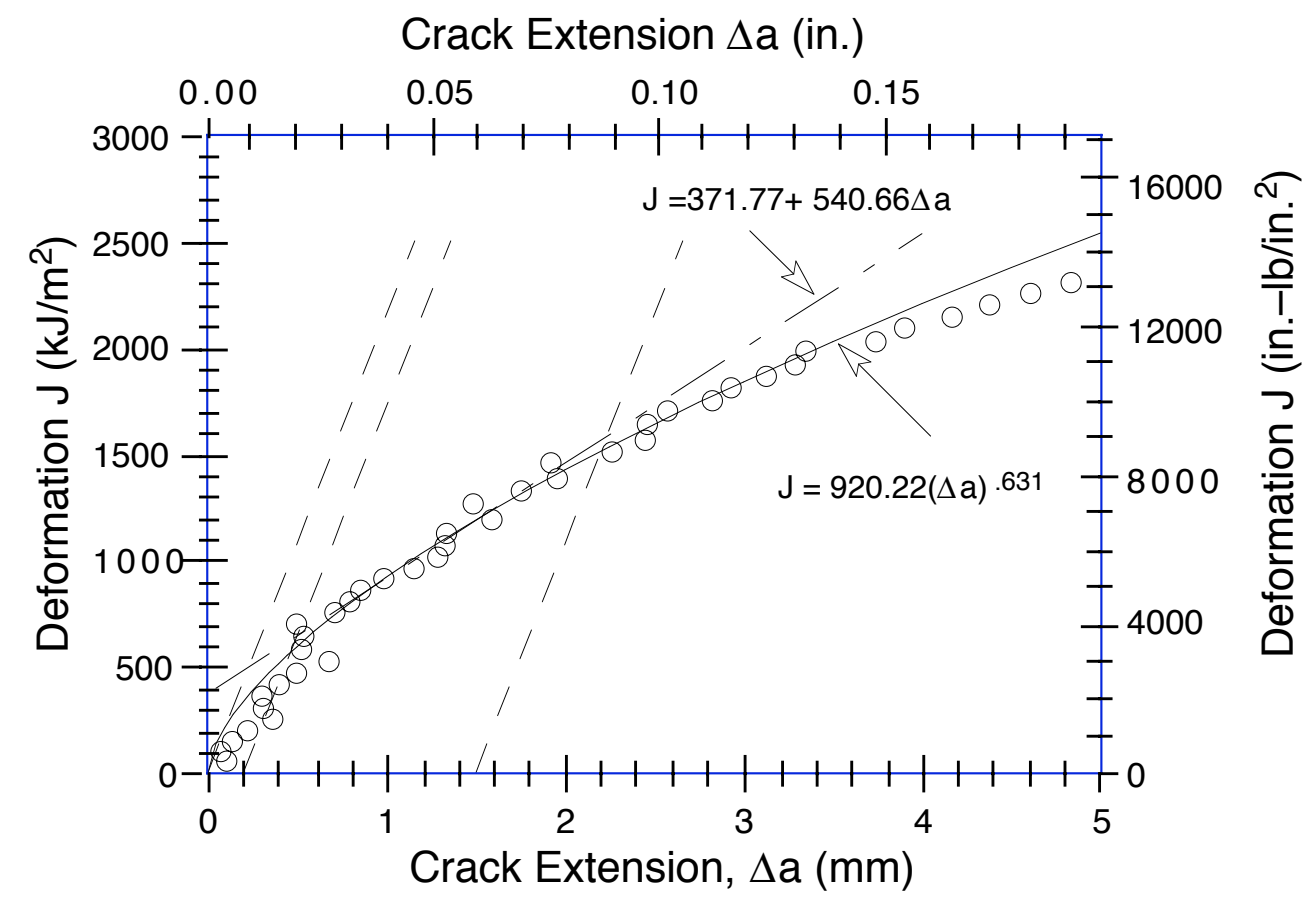

Figure A-5. Deformation J-R curve for weld metal specimen PWCE-04 aged at $400^{\circ} \mathrm{C}$ for $10,000 \mathrm{~h}$ and tested at $25^{\circ} \mathrm{C}$. Blunting, 0.2- $\mathrm{mm}$ offset, and 1.5- $\mathrm{mm}$ offset lines are shown as dashed lines.

Crack Extension $\Delta \mathrm{a}$ (in.)

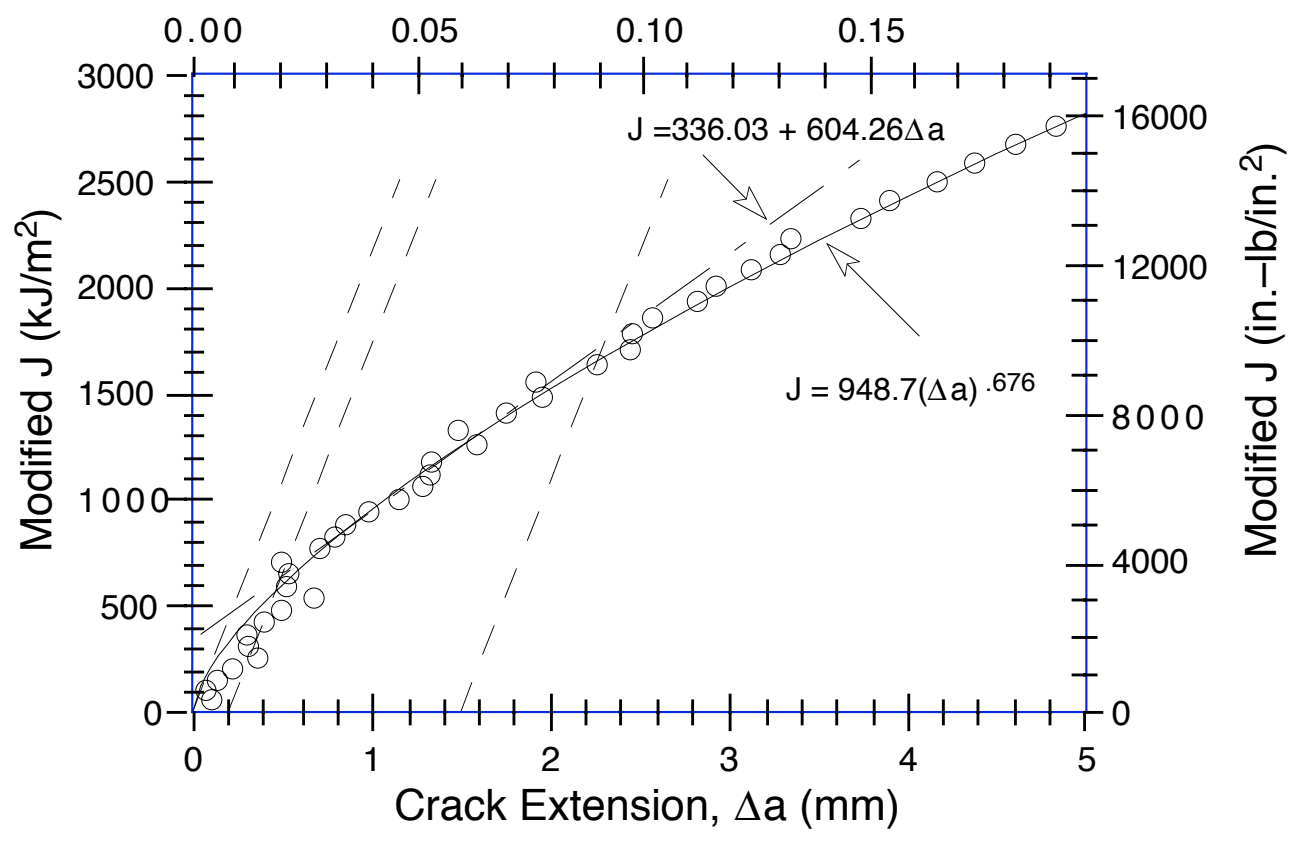

Figure A-6. Modified $\mathrm{J}-R$ curve for weld metal specimen PWCE-04 aged at $400^{\circ} \mathrm{C}$ for $10,000 \mathrm{~h}$ and tested at $25^{\circ} \mathrm{C}$. Blunting, 0.2- $\mathrm{mm}$ offset, and 1.5-mm offset lines are shown as dashed lines. 
Table A-7. Test data for specimen PWCE-01

$\begin{array}{llll}\text { Test Number } & : 0123 & \text { Test Temp } & : 290^{\circ} \mathrm{C} \\ \text { Material Type } & : \text { Weld Metal } & \text { Heat Number } & : \text { PWCE } \\ \text { Aging Temp } & : \text { Unaged } & \text { Aging Time } & :- \\ \text { Thickness } & : 25.35 \mathrm{~mm} & \text { Net Thickness } & : 20.23 \mathrm{~mm} \\ \text { Width } & : 50.81 \mathrm{~mm} & \text { Flow Stress } & : 373.00 \mathrm{MPa}\end{array}$

\begin{tabular}{crrrrr}
\hline $\begin{array}{c}\text { Unload } \\
\text { Number }\end{array}$ & $\begin{array}{c}J_{\mathrm{d}} \\
\left(\mathrm{kJ} / \mathrm{m}^{2}\right)\end{array}$ & $\begin{array}{c}J_{\mathrm{m}} \\
\left(\mathrm{kJ} / \mathrm{m}^{2}\right)\end{array}$ & $\begin{array}{c}\Delta \mathrm{a} \\
(\mathrm{m} \mathrm{m})\end{array}$ & $\begin{array}{c}\text { Load } \\
(\mathrm{kN})\end{array}$ & $\begin{array}{c}\text { Deflection } \\
(\mathrm{m} \mathrm{m})\end{array}$ \\
\hline & & & & & \\
1 & 12.83 & 12.81 & -0.1801 & 20.644 & 0.251 \\
2 & 37.25 & 37.52 & 0.1993 & 30.462 & 0.439 \\
3 & 61.29 & 61.62 & 0.2326 & 35.392 & 0.603 \\
4 & 87.70 & 87.93 & 0.2021 & 38.210 & 0.754 \\
5 & 126.10 & 125.84 & 0.1014 & 40.378 & 0.955 \\
6 & 177.86 & 179.53 & 0.3499 & 41.933 & 1.209 \\
7 & 238.23 & 236.54 & 0.0504 & 43.008 & 1.508 \\
8 & 322.42 & 328.92 & 0.5599 & 43.798 & 1.907 \\
9 & 407.13 & 406.81 & 0.2347 & 44.160 & 2.307 \\
10 & 490.72 & 502.15 & 0.6859 & 44.638 & 2.707 \\
11 & 568.31 & 588.66 & 0.9751 & 44.736 & 3.106 \\
12 & 635.35 & 651.68 & 0.8596 & 44.684 & 3.408 \\
13 & 762.11 & 790.63 & 1.1449 & 44.379 & 4.007 \\
14 & 816.01 & 857.48 & 1.4240 & 44.091 & 4.309 \\
15 & 874.14 & 922.90 & 1.5692 & 43.745 & 4.608 \\
16 & 933.05 & 992.24 & 1.7619 & 43.685 & 4.915 \\
17 & 996.51 & 1057.48 & 1.7925 & 43.150 & 5.213 \\
18 & 1057.56 & 1124.85 & 1.8940 & 42.565 & 5.511 \\
19 & 1111.88 & 1192.11 & 2.0899 & 42.117 & 5.810 \\
20 & 1157.57 & 1260.04 & 2.4092 & 41.654 & 6.114 \\
21 & 1203.04 & 1323.50 & 2.6550 & 41.250 & 6.407 \\
22 & 1266.45 & 1387.58 & 2.6637 & 40.786 & 6.710 \\
23 & 1291.86 & 1456.96 & 3.2106 & 40.198 & 7.002 \\
24 & 1357.35 & 1515.39 & 3.1271 & 39.708 & 7.309 \\
25 & 1396.36 & 1586.23 & 3.4879 & 39.192 & 7.609 \\
26 & 1443.52 & 1648.33 & 3.6503 & 38.738 & 7.909 \\
27 & 1504.17 & 1711.50 & 3.6766 & 38.164 & 8.210 \\
28 & 1567.96 & 1800.27 & 3.9228 & 37.593 & 8.609 \\
29 & 1621.83 & 1886.05 & 4.2228 & 36.760 & 9.012 \\
30 & 1712.17 & 1988.23 & 4.3275 & 36.152 & 9.509 \\
31 & 1795.79 & 2116.11 & 4.6941 & 34.843 & 10.108 \\
32 & 1883.58 & 2236.71 & 4.9499 & 34.106 & 10.707 \\
33 & 1949.08 & 2381.69 & 5.5332 & 32.721 & 11.409 \\
34 & 2027.78 & 2516.87 & 5.9239 & 31.415 & 12.108 \\
35 & 2071.46 & 2654.72 & 6.5429 & 29.993 & 12.808 \\
36 & 2149.20 & 2784.49 & 6.8670 & 29.065 & 13.511 \\
37 & 2226.28 & 2917.01 & 7.1945 & 28.289 & 14.207 \\
38 & 2306.57 & 3049.09 & 7.4851 & 27.281 & 14.911 \\
& & & & & \\
\hline & & & & &
\end{tabular}


Table A-8. Deformation J/C and J-R curve results for specimen PWCE-01

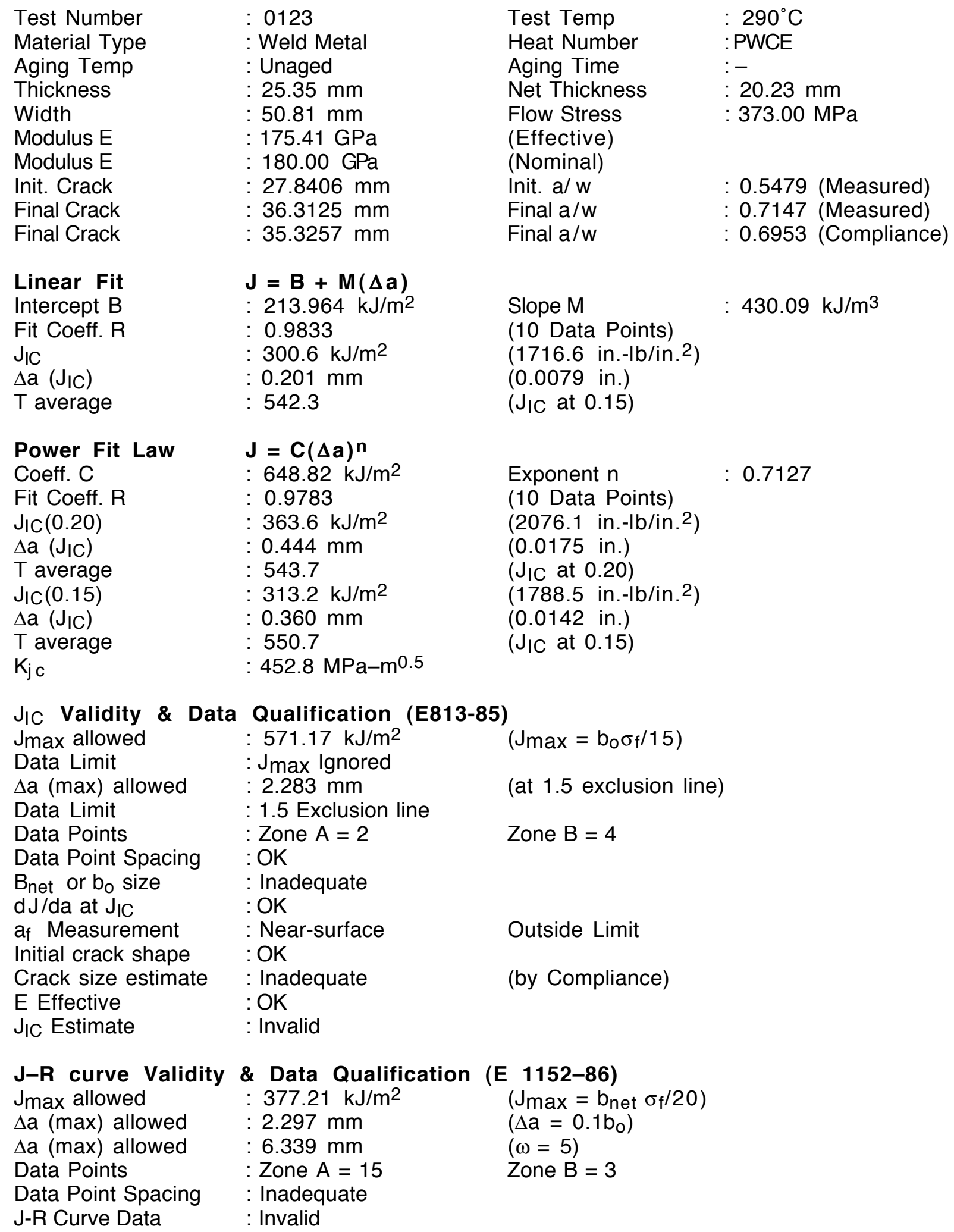


Table A-9. Modified J/C and J-R curve results for specimen PWCE-01

\begin{tabular}{|c|c|c|c|}
\hline $\begin{array}{l}\text { Linear Fit } \\
\text { Intercept B } \\
\text { Fit Coeff. R } \\
J_{I C} \\
\Delta \text { a }\left(\mathrm{J}_{\mathrm{IC}}\right) \\
\mathrm{T} \text { average }\end{array}$ & $\begin{array}{l}\mathbf{J}=\mathbf{B}+\mathbf{M}(\mathbf{\Delta} \mathbf{a}) \\
: 187.921 \mathrm{~kJ} / \mathrm{m}^{2} \\
: 0.9864 \\
: 276.8 \mathrm{~kJ} / \mathrm{m}^{2} \\
: 0.186 \mathrm{~mm} \\
: 604.0\end{array}$ & $\begin{array}{l}\text { Slope M } \\
\text { (10 Data Points) } \\
\left(1580.5 \text { in.-lb/in. }{ }^{2}\right) \\
(0.0073 \text { in. }) \\
\left(J_{I C} \text { at } 0.15\right)\end{array}$ & : $479.05 \mathrm{~kJ} / \mathrm{m}^{3}$ \\
\hline $\begin{array}{l}\text { Power-Law Fit } \\
\text { Coeff. C } \\
\text { Fit Coeff. R } \\
\mathrm{J}_{\mathrm{IC}}(0.20) \\
\Delta \mathrm{a}\left(\mathrm{J}_{\mathrm{IC}}\right) \\
\mathrm{T} \text { average } \\
\mathrm{J}_{\mathrm{IC}}(0.15) \\
\Delta \mathrm{a}\left(\mathrm{J}_{\mathrm{IC}}\right) \\
\mathrm{T}_{\mathrm{C}} \text { average } \\
\mathrm{K}_{\mathrm{j}} \mathrm{C}\end{array}$ & $\begin{array}{l}\mathbf{J}=\mathbf{C}(\Delta \mathbf{a})^{\mathbf{n}} \\
: 671.99 \mathrm{~kJ} / \mathrm{m}^{2} \\
: 0.9816 \\
: 363.6 \mathrm{~kJ} / \mathrm{m}^{2} \\
: 0.444 \mathrm{~mm} \\
: 599.2 \\
: 308.2 \mathrm{~kJ} / \mathrm{m}^{2} \\
: 0.357 \mathrm{~mm} \\
: 605.8 \\
: 475.1 \mathrm{MPa}-\mathrm{m}^{0.5}\end{array}$ & $\begin{array}{l}\text { Exponent } n \\
(10 \text { Data Points) } \\
\left(2076.2 \text { in.-lb/in. }{ }^{2}\right) \\
(0.0175 \text { in. }) \\
\left(J_{I C} \text { at } 0.20\right) \\
\left(1760.0 \text { in.-lb/in. }{ }^{2}\right) \\
(0.0140 \text { in. }) \\
\left(J_{I C} \text { at } 0.15\right)\end{array}$ & 0.7558 \\
\hline
\end{tabular}

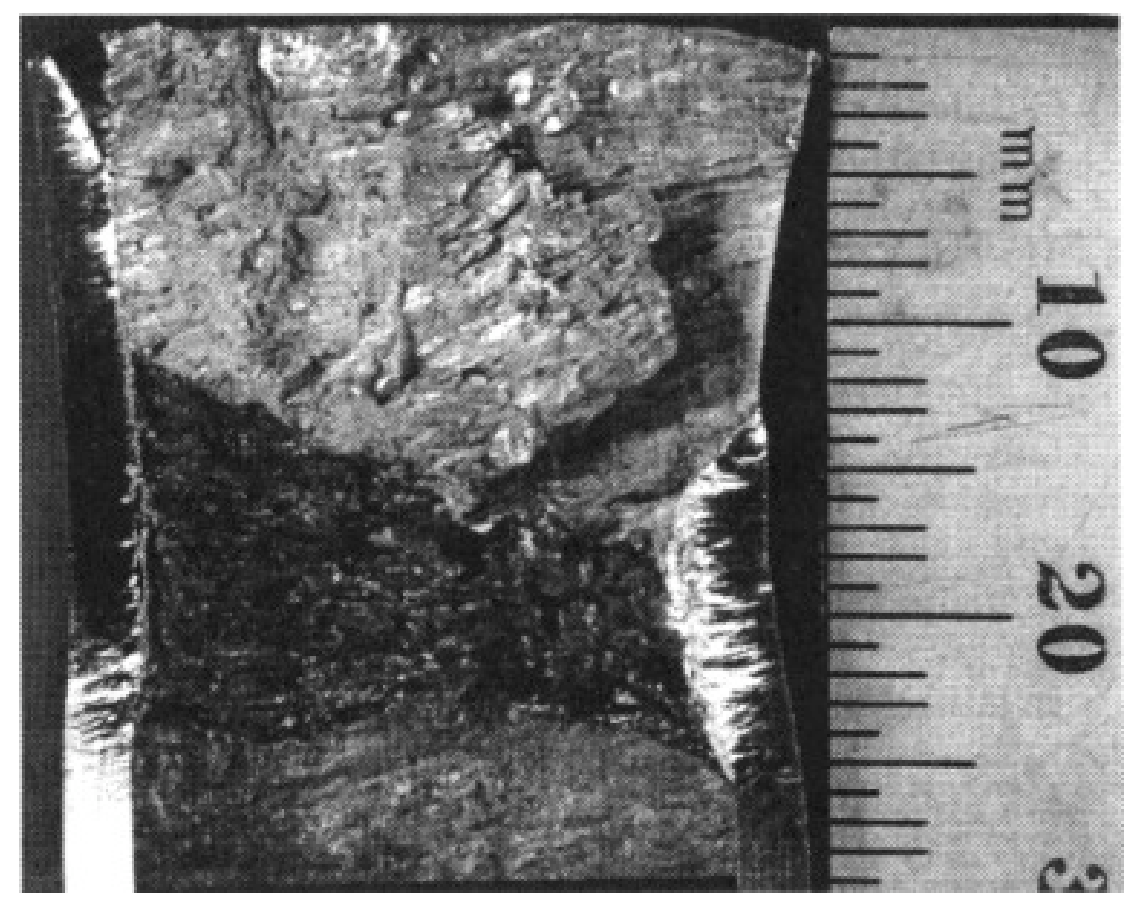

Figure A-7. Fracture surface of unaged weld metal PWCE tested at $290^{\circ} \mathrm{C}$ 


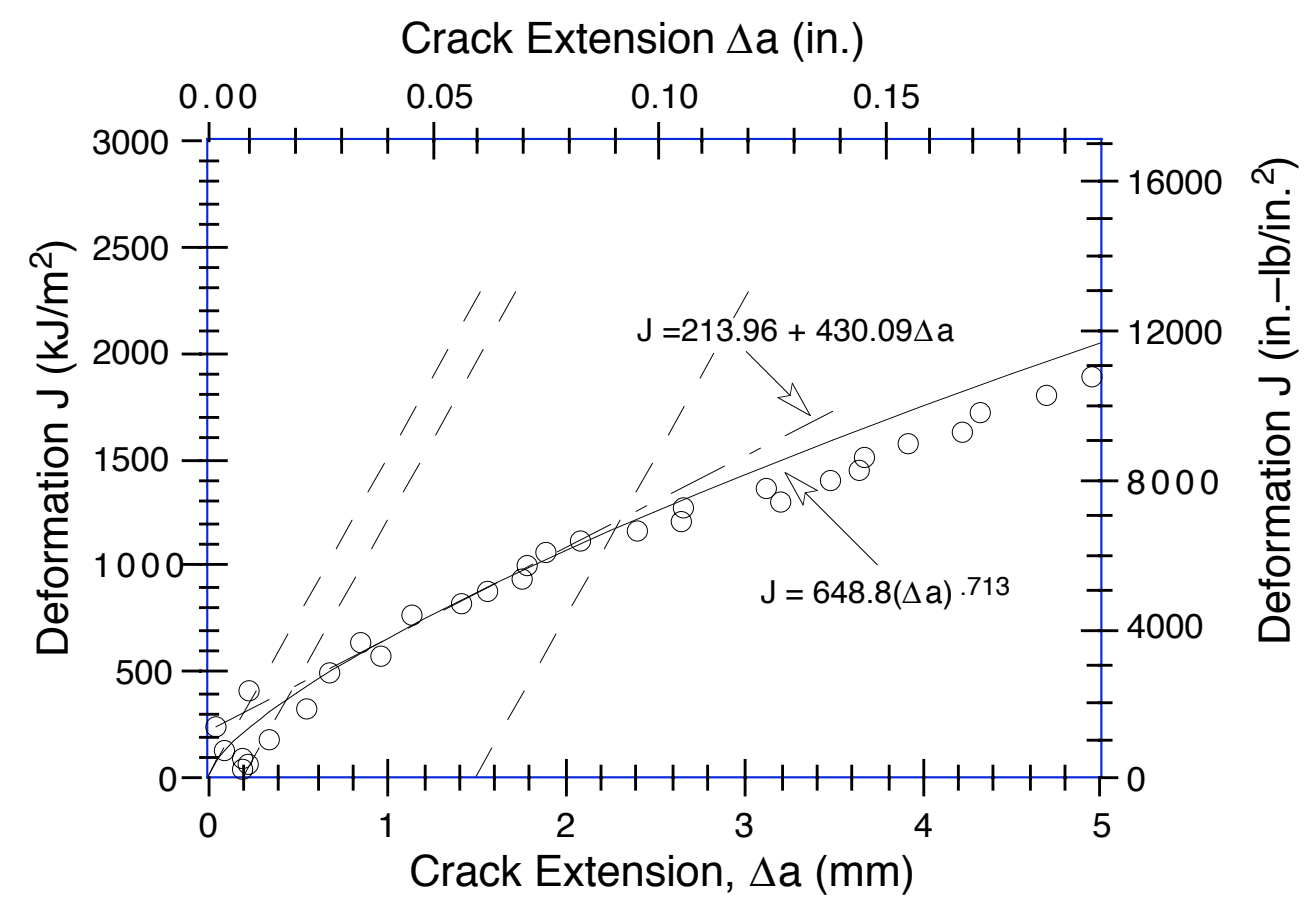

Figure $A-8$. Deformation $J-R$ curve for unaged weld metal specimen PWCE-01 tested at $290^{\circ} \mathrm{C}$. Blunting, 0.2- $\mathrm{mm}$ offset, and 1.5- $\mathrm{mm}$ offset lines are shown as dashed lines.

Crack Extension $\Delta \mathrm{a}$ (in.)

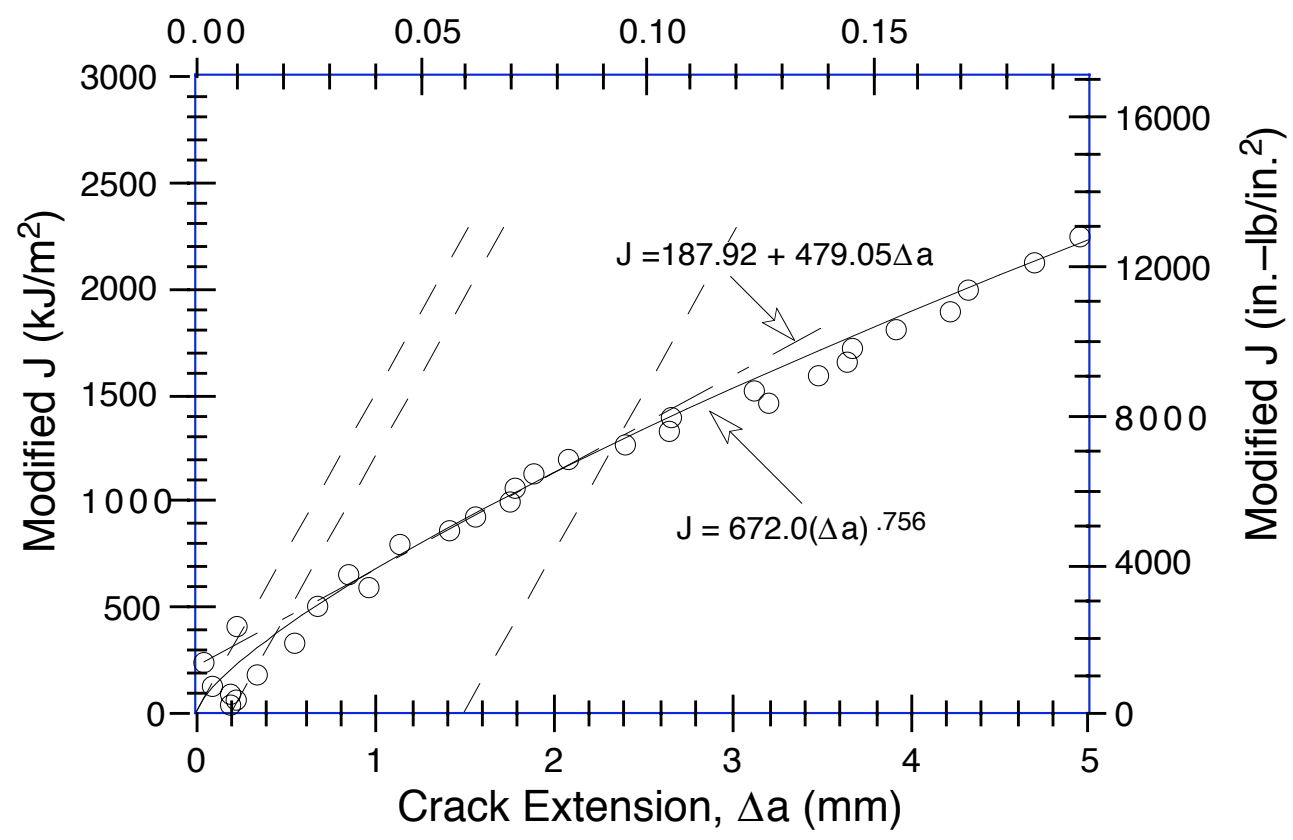

Figure A-9. Modified $J-R$ curve for unaged weld metal specimen PWCE-01 tested at $290^{\circ} \mathrm{C}$. Blunting, 0.2- $\mathrm{mm}$ offset, and 1.5- $\mathrm{mm}$ offset lines are shown as dashed lines. 
Table A-10. Test data for specimen PWCE-03

$\begin{array}{llll}\text { Test Number } & : 0127 & \text { Test Temp } & : 290^{\circ} \mathrm{C} \\ \text { Material Type } & : \text { Weld Metal } & \text { Heat Number } & : \text { PWCE } \\ \text { Aging Temp } & : 400^{\circ} \mathrm{C} & \text { Aging Time } & : 10,000 \mathrm{~h} \\ \text { Thickness } & : 25.35 \mathrm{~mm} & \text { Net Thickness } & : 20.26 \mathrm{~mm} \\ \text { Width } & : 50.82 \mathrm{~mm} & \text { Flow Stress } & : 406.00 \mathrm{MPa}\end{array}$

\begin{tabular}{|c|c|c|c|c|c|}
\hline $\begin{array}{l}\text { Unload } \\
\text { Number }\end{array}$ & $\begin{array}{c}J_{d} \\
\left(k J / m^{2}\right)\end{array}$ & $\begin{array}{c}J_{m} \\
\left(k J / m^{2}\right)\end{array}$ & $\begin{array}{c}\Delta \mathrm{a} \\
(\mathrm{mm})\end{array}$ & $\begin{array}{l}\text { Load } \\
(k N)\end{array}$ & $\begin{array}{c}\text { Deflection } \\
(\mathrm{mm})\end{array}$ \\
\hline 1 & 13.29 & 13.26 & -0.2959 & 21.718 & 0.252 \\
\hline 2 & 48.82 & 49.04 & -0.0594 & 34.743 & 0.503 \\
\hline 3 & 92.42 & 92.59 & -0.0738 & 40.085 & 0.755 \\
\hline 4 & 142.70 & 143.64 & 0.0613 & 42.514 & 1.006 \\
\hline 5 & 203.93 & 204.99 & 0.0748 & 44.024 & 1.305 \\
\hline 6 & 268.19 & 270.91 & 0.2063 & 44.840 & 1.606 \\
\hline 7 & 340.56 & 346.12 & 0.3738 & 45.440 & 1.946 \\
\hline 8 & 384.47 & 392.79 & 0.5157 & 45.613 & 2.157 \\
\hline 9 & 418.08 & 427.09 & 0.5480 & 45.984 & 2.315 \\
\hline 10 & 461.11 & 470.04 & 0.5447 & 45.862 & 2.505 \\
\hline 11 & 526.21 & 541.32 & 0.7650 & 45.508 & 2.809 \\
\hline 12 & 586.62 & 609.83 & 1.0197 & 45.358 & 3.112 \\
\hline 13 & 649.24 & 675.58 & 1.1072 & 45.006 & 3.410 \\
\hline 14 & 715.39 & 743.40 & 1.1491 & 44.861 & 3.711 \\
\hline 15 & 769.56 & 814.16 & 1.5298 & 44.556 & 4.008 \\
\hline 16 & 831.39 & 878.96 & 1.5925 & 43.992 & 4.312 \\
\hline 17 & 878.66 & 951.43 & 2.0852 & 43.519 & 4.612 \\
\hline 18 & 938.35 & 1013.63 & 2.1308 & 42.737 & 4.916 \\
\hline 19 & 987.24 & 1082.53 & 2. 4709 & 42.248 & 5.208 \\
\hline 20 & 1035.47 & 1148.47 & 2.7541 & 41.333 & 5.510 \\
\hline 21 & 1094.81 & 1211.85 & 2.8147 & 40.599 & 5.810 \\
\hline 22 & 1131.50 & 1282.96 & 3.3051 & 39.741 & 6.114 \\
\hline 23 & 1187.67 & 1340.28 & 3.3208 & 38.887 & 6.410 \\
\hline 24 & 1215.85 & 1410.90 & 3.8681 & 37.802 & 6.712 \\
\hline 25 & 1254.21 & 1469.43 & 4.1176 & 37.194 & 7.011 \\
\hline 26 & 1305.12 & 1555.82 & 4.5313 & 36.101 & 7.412 \\
\hline 27 & 1356.82 & 1635.95 & 4.8448 & 34.645 & 7.807 \\
\hline 28 & 1398.49 & 1719.30 & 5.2817 & 33.541 & 8.212 \\
\hline 29 & 1448.15 & 1795.89 & 5.5504 & 32.323 & 8.609 \\
\hline 30 & 1488.61 & 1875.12 & 5.9200 & 31.525 & 9.006 \\
\hline 31 & 1528.97 & 1952.44 & 6.2572 & 30.453 & 9.408 \\
\hline 32 & 1554.22 & 2028.49 & 6.7030 & 29.254 & 9.806 \\
\hline 33 & 1584.47 & 2101.34 & 7.0628 & 28.037 & 10.208 \\
\hline 34 & 1614.20 & 2174.19 & 7.4134 & 26.958 & 10.609 \\
\hline 35 & 1641.89 & 2245.24 & 7.7533 & 25.676 & 11.010 \\
\hline 36 & 1668.64 & 2331.92 & 8.2042 & 24.637 & 11.503 \\
\hline 37 & 1684.56 & 2422.65 & 8.7445 & 23.133 & 12.038 \\
\hline 38 & 1692.95 & 2497.17 & 9.2065 & 21.699 & 12.506 \\
\hline 39 & 1696.54 & 2576.25 & 9.7165 & 20.460 & 13.010 \\
\hline 40 & 1722.21 & 2650.89 & 10.0356 & 19.644 & 13.510 \\
\hline 41 & 1736.13 & 2727.87 & 10.4324 & 18.589 & 14.007 \\
\hline 42 & 1752.21 & 2801.71 & 10.7837 & 17.719 & 14.510 \\
\hline 43 & 1771.22 & 2873.68 & 11.0952 & 16.820 & 15.008 \\
\hline
\end{tabular}


Table A-11. Deformation J/C and J-R curve results for specimen PWCE-03

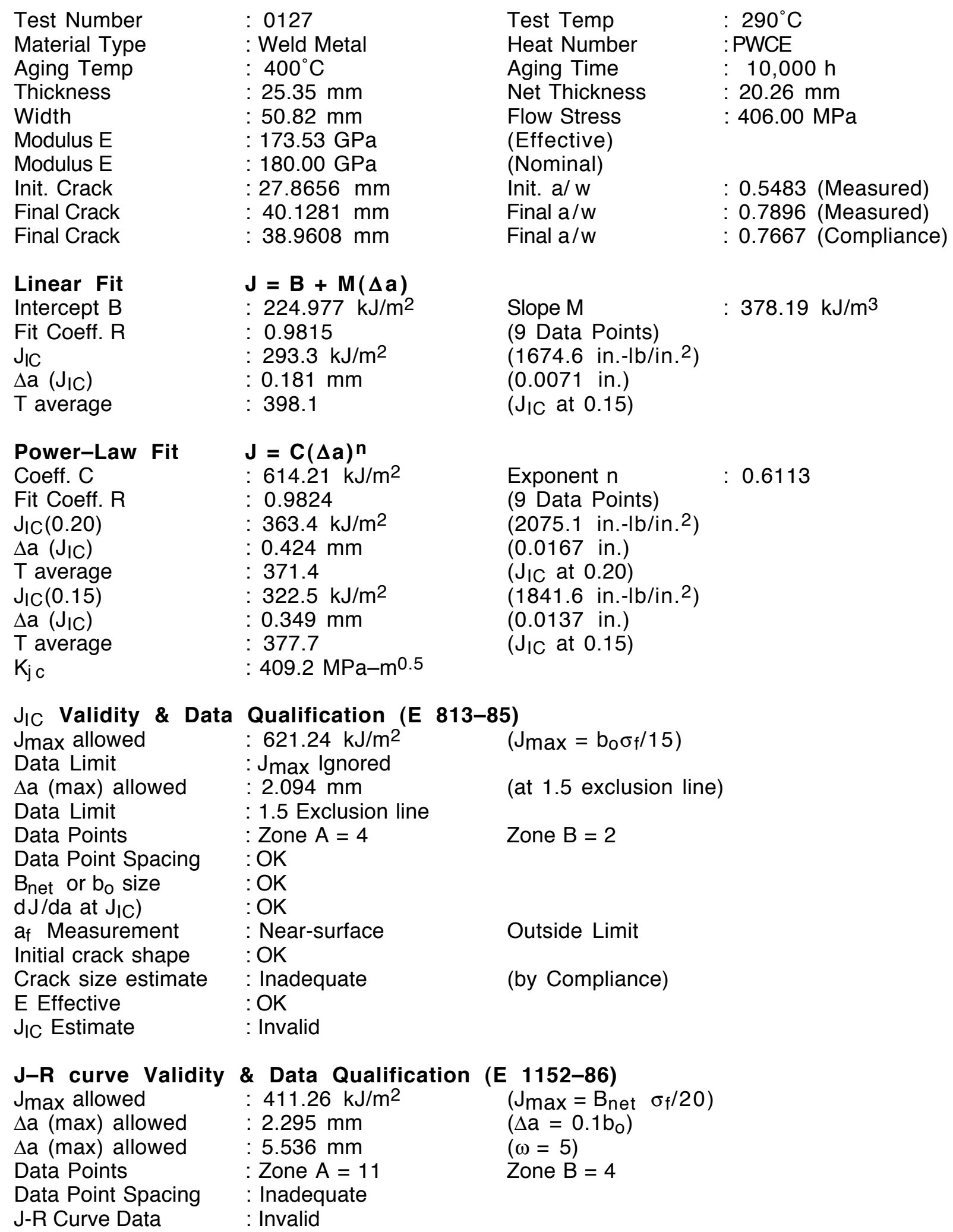


Table A-12. Modified J/C and J-R curve results for specimen PWCE-03

\begin{tabular}{|c|c|c|c|}
\hline $\begin{array}{l}\text { Linear Fit } \\
\text { Intercept B } \\
\text { Fit Coeff. R } \\
\mathrm{J}_{\mathrm{IC}} \\
\Delta \mathrm{a}\left(\mathrm{J}_{\mathrm{IC}}\right) \\
\mathrm{T} \text { average }\end{array}$ & $\begin{array}{l}\mathbf{J}=\mathbf{B}+\mathbf{M}(\boldsymbol{\Delta} \mathbf{a}) \\
: 255.972 \mathrm{~kJ} / \mathrm{m}^{2} \\
: 0.9778 \\
: 329.8 \mathrm{~kJ} / \mathrm{m}^{2} \\
: 0.203 \mathrm{~mm} \\
: 382.5\end{array}$ & $\begin{array}{l}\text { Slope M } \\
\text { (10 Data Points) } \\
\left(1882.9 \text { in.-lb/in. }{ }^{2}\right) \\
(0.0080 \text { in. }) \\
\left(J_{I C} \text { at } 0.15\right)\end{array}$ & $363.36 \mathrm{~kJ} / \mathrm{m}^{3}$ \\
\hline $\begin{array}{l}\text { Power-Law Fit } \\
\text { Coeff. C } \\
\text { Fit Coeff. R } \\
\mathrm{J}_{\mathrm{IC}}(0.20) \\
\Delta \mathrm{a}\left(\mathrm{J}_{\mathrm{IC}}\right) \\
\mathrm{T} \text { average } \\
\mathrm{J}_{\mathrm{IC}}(0.15) \\
\Delta \mathrm{a}\left(\mathrm{J}_{\mathrm{IC}}\right) \\
T \text { average } \\
\mathrm{K}_{\mathrm{j}} \mathrm{C}\end{array}$ & 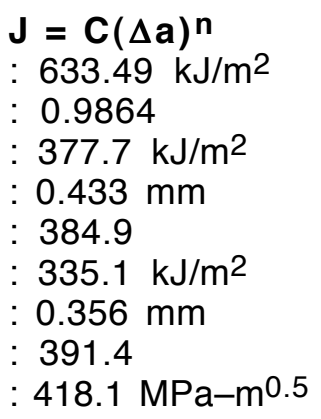 & $\begin{array}{l}\text { Exponent } n \\
(10 \text { Data Points) } \\
\left(2156.5 \text { in.-lb/in. }{ }^{2}\right) \\
(0.0170 \text { in.) } \\
\left(\mathrm{J}_{\mid C} \text { at } 0.20\right) \\
\left(1913.3 \text { in.-lb/in. }{ }^{2}\right) \\
(0.0140 \text { in. }) \\
\left(J_{I C} \text { at } 0.15\right)\end{array}$ & 0.6172 \\
\hline
\end{tabular}

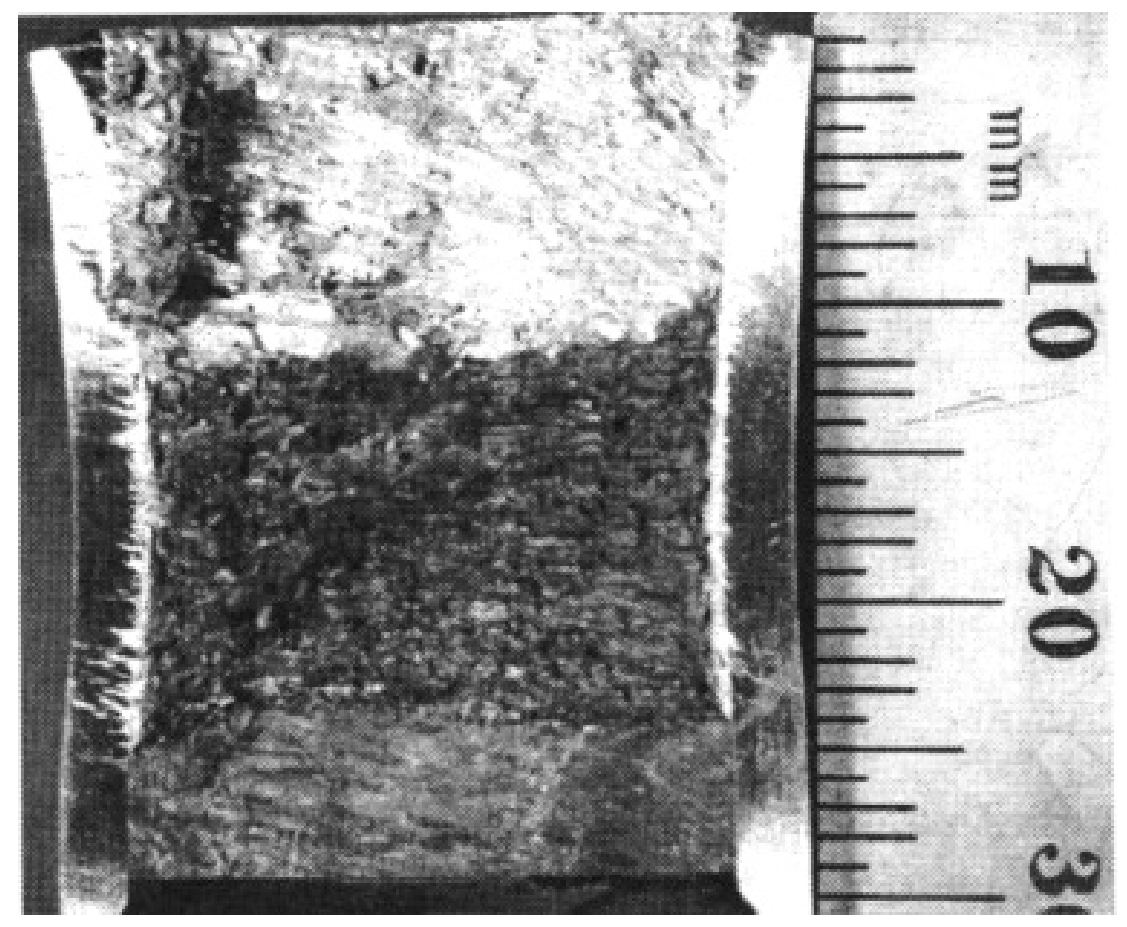

Figure A-10. Fracture surface of aged weld metal PWCE tested at $290^{\circ} \mathrm{C}$ 


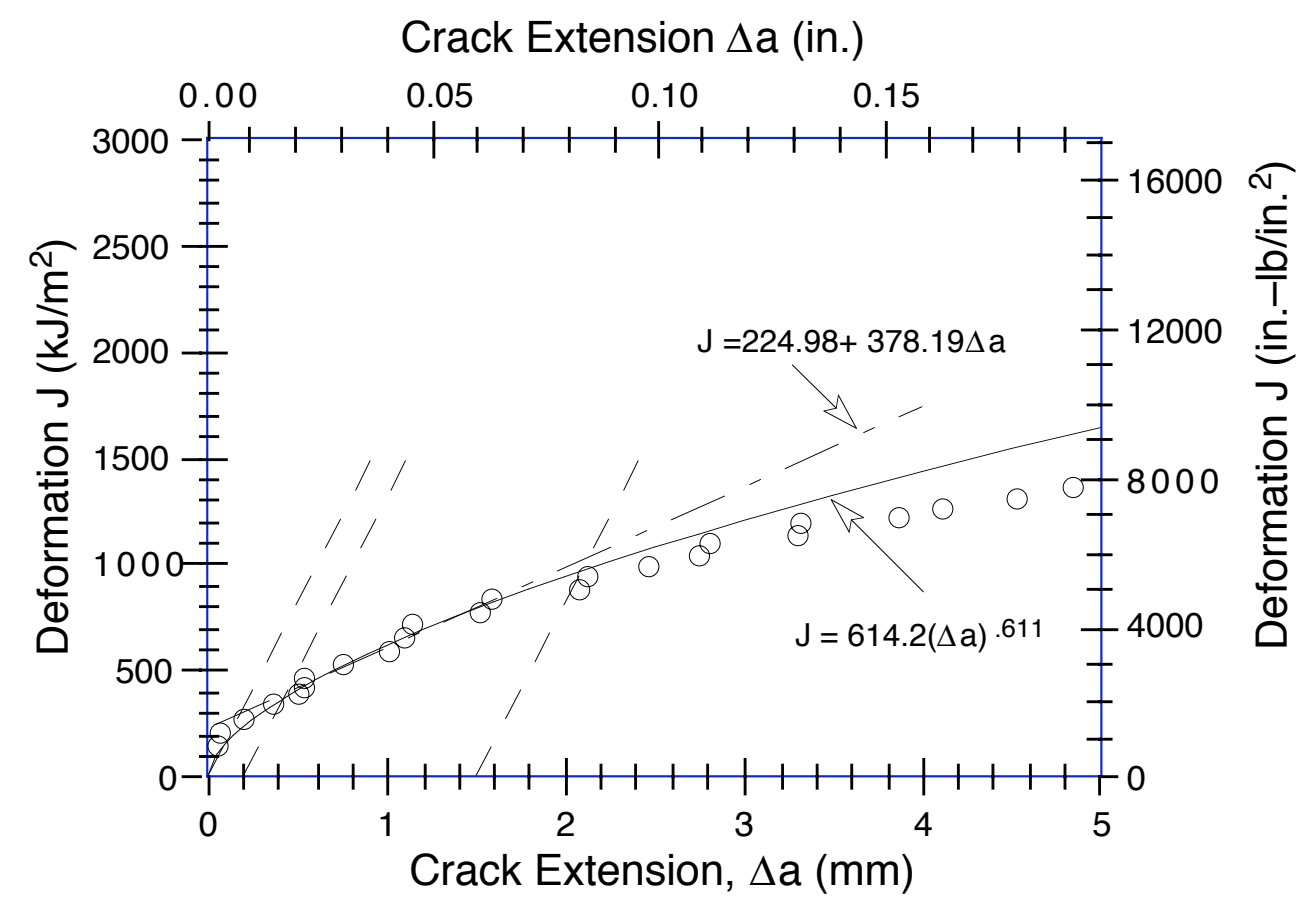

Figure A-11. Deformation J-R curve for weld metal specimen PWCE-03 aged at $400^{\circ} \mathrm{C}$ for $10,000 \mathrm{~h}$ and tested at $290^{\circ} \mathrm{C}$. Blunting, 0.2- $\mathrm{mm}$ offset, and 1.5- $\mathrm{mm}$ offset lines are shown as dashed lines.

Crack Extension $\Delta \mathrm{a}$ (in.)

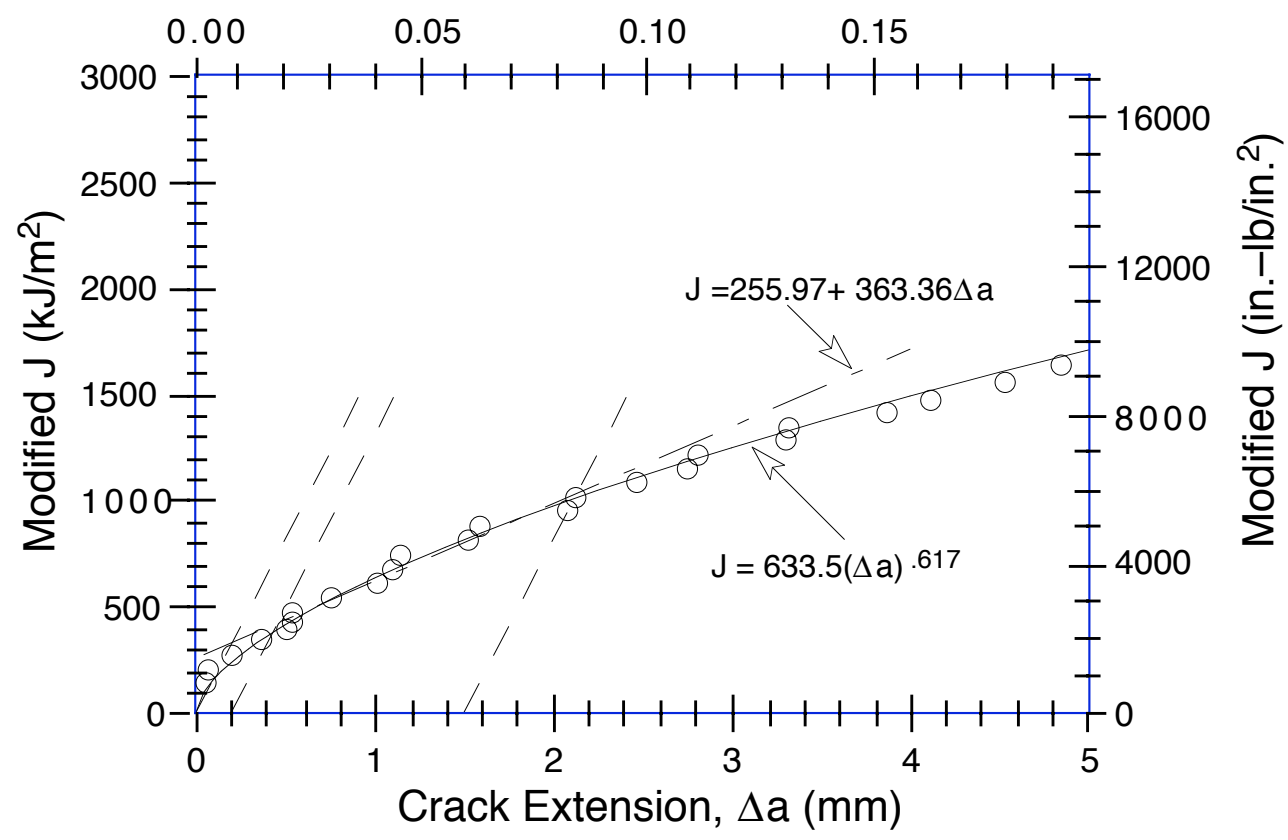

Figure A-12. Modified $\mathrm{J}-R$ curve for weld metal specimen PWCE-03 aged at $400^{\circ} \mathrm{C}$ for $10,000 \mathrm{~h}$ and tested at $290^{\circ} \mathrm{C}$. Blunting, 0.2- $\mathrm{mm}$ offset, and 1.5-mm offset lines are shown as dashed lines. 
Table A-13. Test data for specimen PWWO-03

$\begin{array}{ll}\text { Test Number } & : 0131 \\ \text { Material Type } & : \text { Weld Metal } \\ \text { Aging Temp } & : 400^{\circ} \mathrm{C} \\ \text { Thickness } & : 22.84 \mathrm{~mm} \\ \text { Width } & : 50.76 \mathrm{~mm}\end{array}$

$\begin{array}{ll}\text { Test Temp } & : 25^{\circ} \mathrm{C} \\ \text { Heat Number } & : \text { PWWO } \\ \text { Aging Time } & : 7,700 \mathrm{~h} \\ \text { Net Thickness } & : 18.24 \mathrm{~mm} \\ \text { Flow Stress } & : 549.00 \mathrm{MPa}\end{array}$

\begin{tabular}{|c|c|c|c|c|c|}
\hline $\begin{array}{c}\text { Unload } \\
\text { Number }\end{array}$ & $\begin{array}{c}J_{d} \\
\left(k J / m^{2}\right)\end{array}$ & $\begin{array}{c}J_{m} \\
\left(k J / m^{2}\right)\end{array}$ & $\begin{array}{c}\Delta \mathrm{a} \\
(\mathrm{m} \mathrm{m})\end{array}$ & $\begin{array}{l}\text { Load } \\
(\mathrm{kN})\end{array}$ & $\begin{array}{c}\text { Deflection } \\
(\mathrm{mm})\end{array}$ \\
\hline 1 & 14.72 & 14.71 & -0.1327 & 22.208 & 0.251 \\
\hline 2 & 54.82 & 54.89 & -0.0506 & 37.282 & 0.501 \\
\hline 3 & 121.93 & 122.42 & 0.0628 & 45.593 & 0.804 \\
\hline 4 & 197.25 & 199.04 & 0.2348 & 48.740 & 1.105 \\
\hline 5 & 248.49 & 251.71 & 0.3722 & 49.830 & 1.307 \\
\hline 6 & 301.06 & 304.73 & 0.4053 & 50.334 & 1.508 \\
\hline 7 & 355.13 & 361.66 & 0.5785 & 50.803 & 1.708 \\
\hline 8 & 408.54 & 414.43 & 0.5465 & 50.841 & 1.909 \\
\hline 9 & 462.44 & 474.26 & 0.8048 & 50.723 & 2.109 \\
\hline 10 & 511.68 & 528.21 & 0.9859 & 50.696 & 2.308 \\
\hline 11 & 562.26 & 583.59 & 1.1511 & 50.674 & 2.508 \\
\hline 12 & 611.13 & 641.88 & 1.4423 & 49.896 & 2.710 \\
\hline 13 & 656.37 & 697.14 & 1.7259 & 49.328 & 2.911 \\
\hline 14 & 704.03 & 749.75 & 1.8546 & 48.782 & 3.109 \\
\hline 15 & 750.58 & 807.86 & 2.1310 & 48.012 & 3.310 \\
\hline 16 & 794.30 & 860.69 & 2.3343 & 47.476 & 3.508 \\
\hline 17 & 837.91 & 916.55 & 2.5895 & 46.807 & 3.709 \\
\hline 18 & 881.75 & 970.78 & 2.7923 & 45.981 & 3.912 \\
\hline 19 & 922.61 & 1024.84 & 3.0348 & 44.773 & 4.111 \\
\hline 20 & 960.36 & 1076.86 & 3.2832 & 44.133 & 4.307 \\
\hline 21 & 996.69 & 1130.87 & 3.5756 & 43.191 & 4.510 \\
\hline 22 & 1038.55 & 1196.72 & 3.9496 & 42.042 & 4.759 \\
\hline 23 & 1078.32 & 1259.91 & 4.2944 & 40.692 & 5.009 \\
\hline 24 & 1118.11 & 1322.82 & 4.6170 & 39.197 & 5.260 \\
\hline 25 & 1155.41 & 1383.87 & 4.9324 & 38.266 & 5.507 \\
\hline 26 & 1188.08 & 1446.55 & 5.3128 & 36.947 & 5.759 \\
\hline 27 & 1217.23 & 1504.98 & 5.6683 & 35.671 & 6.007 \\
\hline 28 & 1250.15 & 1577.64 & 6.1262 & 33.694 & 6.308 \\
\hline 29 & 1276.82 & 1644.22 & 6.5668 & 32.460 & 6.606 \\
\hline 30 & 1308.24 & 1710.28 & 6.9322 & 31.030 & 6.909 \\
\hline 31 & 1336.65 & 1775.83 & 7.3079 & 29.969 & 7.207 \\
\hline 32 & 1361.38 & 1839.87 & 7.6895 & 28.553 & 7.506 \\
\hline 33 & 1381.79 & 1902.79 & 8.0875 & 27.549 & 7.806 \\
\hline 34 & 1415.11 & 1962.18 & 8.3221 & 26.465 & 8.107 \\
\hline 35 & 1441.41 & 2049.61 & 8.8452 & 24.941 & 8.508 \\
\hline 36 & 1461.70 & 2123.18 & 9.2825 & 23.576 & 8.898 \\
\hline 37 & 1485.33 & 2200.96 & 9.7080 & 22.275 & 9.307 \\
\hline 38 & 1512.30 & 2272.98 & 10.0476 & 21.246 & 9.704 \\
\hline 39 & 1536.51 & 2347.13 & 10.4091 & 20.376 & 10.108 \\
\hline 40 & 1565.06 & 2437.82 & 10.8374 & 19.166 & 10.606 \\
\hline
\end{tabular}


Table A-14. Deformation J/C and J-R curve results for specimen PWWO-03

\begin{tabular}{|c|c|c|c|}
\hline Test Number & $: 0131$ & Test Temp & $: 25^{\circ} \mathrm{C}$ \\
\hline Material Type & : Weld Metal & Heat Number & : PWWO \\
\hline Aging Temp & $: 400^{\circ} \mathrm{C}$ & Aging Time & $: 7,700 \mathrm{~h}$ \\
\hline Thickness & : $22.84 \mathrm{~mm}$ & Net Thickness & : $18.24 \mathrm{~mm}$ \\
\hline Width & : $50.76 \mathrm{~mm}$ & Flow Stress & : $549.00 \mathrm{MPa}$ \\
\hline Modulus E & $: 195.44 \mathrm{GPa}$ & (Effective) & \\
\hline Modulus E & $: 193.10 \mathrm{GPa}$ & (Nominal) & \\
\hline Init. Crack & : $27.8219 \mathrm{~mm}$ & Init. a/ w & : 0.5481 (Measured) \\
\hline Final Crack & : $39.2563 \mathrm{~mm}$ & Final a/w & : 0.7734 (Measured) \\
\hline Final Crack & : $39.0582 \mathrm{~mm}$ & Final a/w & : 0.7695 (Compliance) \\
\hline $\begin{array}{l}\text { Linear Fit } \\
\text { Intercept B } \\
\text { Fit Coeff. R } \\
J_{I C} \\
\Delta \text { a }\left(J_{I C}\right) \\
T \text { average }\end{array}$ & $\begin{array}{l}\mathbf{J}=\mathbf{B}+\mathbf{M}(\Delta \mathbf{a}) \\
: 203.177 \mathrm{~kJ} / \mathrm{m}^{2} \\
: 0.9654 \\
: 233.6 \mathrm{~kJ} / \mathrm{m}^{2} \\
: 0.106 \mathrm{~mm} \\
: 185.2\end{array}$ & $\begin{array}{l}\text { Slope } M \\
\text { (9 Data Points) } \\
(1333.6 \text { in-lb/in } 2) \\
(0.0042 \text { in. }) \\
\left(J_{\text {IC } \text { at } 0.15)}\right.\end{array}$ & : $285.61 \mathrm{~kJ} / \mathrm{m}^{3}$ \\
\hline $\begin{array}{l}\text { Power-Law Fit } \\
\text { Coeff. C } \\
\text { Fit Coeff. R } \\
\mathrm{J}_{\mathrm{IC}}(0.20) \\
\Delta \mathrm{a}\left(\mathrm{J}_{\mathrm{IC}}\right) \\
\mathrm{T} \text { average } \\
\mathrm{J}_{\mathrm{IC}}(0.15) \\
\Delta \mathrm{a}\left(\mathrm{J}_{\mathrm{IC}}\right) \\
\mathrm{T} \text { average } \\
\mathrm{K}_{\mathrm{j} \mathrm{C}}\end{array}$ & $\begin{array}{l}\mathbf{J}=\mathbf{C}(\Delta \mathbf{a})^{\mathbf{n}} \\
: 504.96 \mathrm{~kJ} / \mathrm{m}^{2} \\
: 0.9741 \\
: 257.3 \mathrm{~kJ} / \mathrm{m}^{2} \\
: 0.317 \mathrm{~mm} \\
: 193.2 \\
: 225.1 \mathrm{~kJ} / \mathrm{m}^{2} \\
: 0.252 \mathrm{~mm} \\
: 196.9 \\
: 375.0 \mathrm{MPa}-\mathrm{m}^{0.5}\end{array}$ & $\begin{array}{l}\text { Exponent } \mathrm{n} \\
\text { (9 Data Points) } \\
(1469.4 \text { in-lb/in2) } \\
(0.0125 \text { in. }) \\
\left(\mathrm{J}_{\mid C} \text { at } 0.20\right) \\
(1285.2 \text { in-lb/in } 2) \\
(0.0099 \text { in. }) \\
\left(J_{I C} \text { at } 0.15\right)\end{array}$ & 0.5871 \\
\hline $\begin{array}{l}J_{I C} \text { Validity \& Data } \\
J_{\text {max allowed }} \\
\text { Data Limit } \\
\Delta a \text { (max) allowed } \\
\text { Data Limit } \\
\text { Data Points } \\
\text { Data point spacing } \\
B_{\text {net and bo size }} \\
\text { d J/da at } J_{I C} \\
\text { af Measurement } \\
\text { Initial crack shape } \\
\text { Crack size estimate } \\
\text { E Effective } \\
J_{\text {IC Estimate }}\end{array}$ & $\begin{array}{l}\text { Qualification (E 813- } \\
: 839.50 \mathrm{~kJ} / \mathrm{m}^{2} \\
: \text { Jmax } \\
: 1.828 \mathrm{~mm} \\
: 1.5 \text { Exclusion line } \\
: \text { Zone A = 4 } \\
: \text { OK } \\
: \text { OK } \\
: \text { OK } \\
: \text { Near-surface } \\
: \text { OK } \\
: \text { OK } \\
: \text { OK } \\
: \text { Invalid }\end{array}$ & $\begin{array}{l}35) \\
\left(J_{\max }=b_{o} \sigma_{f} / 15\right) \\
\text { Ignored } \\
\text { (at } 1.5 \text { exclusion line) } \\
\text { Zone } B=2\end{array}$ & \\
\hline $\begin{array}{l}\text { J-R curve Validity } \\
\text { Jmax allowed } \\
\Delta \text { a (max) allowed } \\
\Delta \text { a (max) allowed } \\
\text { Data Points } \\
\text { Data point spacing } \\
\text { J-R Curve Data }\end{array}$ & $\begin{array}{l}\text { \& Data Qualification } \\
: 500.61 \mathrm{~kJ} / \mathrm{m}^{2} \\
: 2.294 \mathrm{~mm} \\
: 5.334 \mathrm{~mm} \\
: \text { Zone A = 4 } \\
: \text { OK } \\
: \text { Invalid }\end{array}$ & $\begin{array}{l}\text { 1152-86) } \\
\left(\mathrm{J}_{\max }=\mathrm{B}_{\text {net }} \sigma_{f} / 20\right) \\
\left(\Delta \mathrm{a}=0.1 \mathrm{~b}_{\mathrm{o}}\right) \\
(\omega=5) \\
\text { Zone } \mathrm{B}=9\end{array}$ & \\
\hline
\end{tabular}


Table A-15. Modified J/C and J-R curve results for specimen PWWO-03

\begin{tabular}{|c|c|c|c|}
\hline $\begin{array}{l}\text { Linear Fit } \\
\text { Intercept B } \\
\text { Fit Coeff. R } \\
J_{I C} \\
\Delta \text { a }\left(\mathrm{J}_{I C}\right) \\
T \text { average }\end{array}$ & $\begin{array}{l}\mathbf{J}=\mathbf{B}+\mathbf{+}(\mathbf{M} \mathbf{a}) \\
: 194.312 \mathrm{~kJ} / \mathrm{m}^{2} \\
: 0.9728 \\
: 226.6 \mathrm{~kJ} / \mathrm{m}^{2} \\
: 0.103 \mathrm{~mm} \\
: 203.0\end{array}$ & 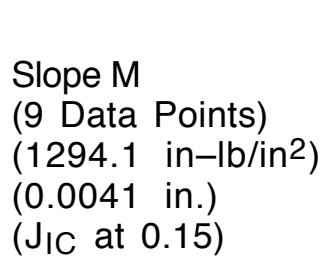 & $313.11 \mathrm{~kJ} / \mathrm{m}^{3}$ \\
\hline $\begin{array}{l}\text { Power-Law Fit } \\
\text { Coeff. C } \\
\text { Fit Coeff. R } \\
\mathrm{J}_{\mathrm{IC}}(0.20) \\
\Delta \mathrm{a}\left(\mathrm{J}_{\mathrm{IC}}\right) \\
\mathrm{T} \text { average } \\
\mathrm{J}_{\mathrm{IC}}(0.15) \\
\Delta \mathrm{a}\left(\mathrm{J}_{\mathrm{IC}}\right) \\
\mathrm{T}_{\text {average }} \\
\mathrm{K}_{\mathrm{j}} \mathrm{C}\end{array}$ & $\begin{array}{l}\mathbf{J}=\mathbf{C}(\Delta \mathbf{a})^{\mathbf{n}} \\
: 523.69 \mathrm{~kJ} / \mathrm{m}^{2} \\
: 0.9785 \\
: 258.0 \mathrm{~kJ} / \mathrm{m}^{2} \\
: 0.317 \mathrm{~mm} \\
: 209.7 \\
: 223.6 \mathrm{~kJ} / \mathrm{m}^{2} \\
: 0.252 \mathrm{~mm} \\
: 213.4 \\
: 386.7 \mathrm{MPa}-\mathrm{m}^{0.5}\end{array}$ & $\begin{array}{l}\text { Exponent } n \\
\text { (9 Data Points) } \\
(1473.0 \text { in-lb/in2) } \\
(0.0125 \text { in. }) \\
\left(J_{\mathrm{IC}} \text { at } 0.20\right) \\
(1276.8 \text { in-lb/in } 2) \\
(0.0099 \text { in.) } \\
\left(J_{I C} \text { at } 0.15\right)\end{array}$ & 0.6171 \\
\hline
\end{tabular}

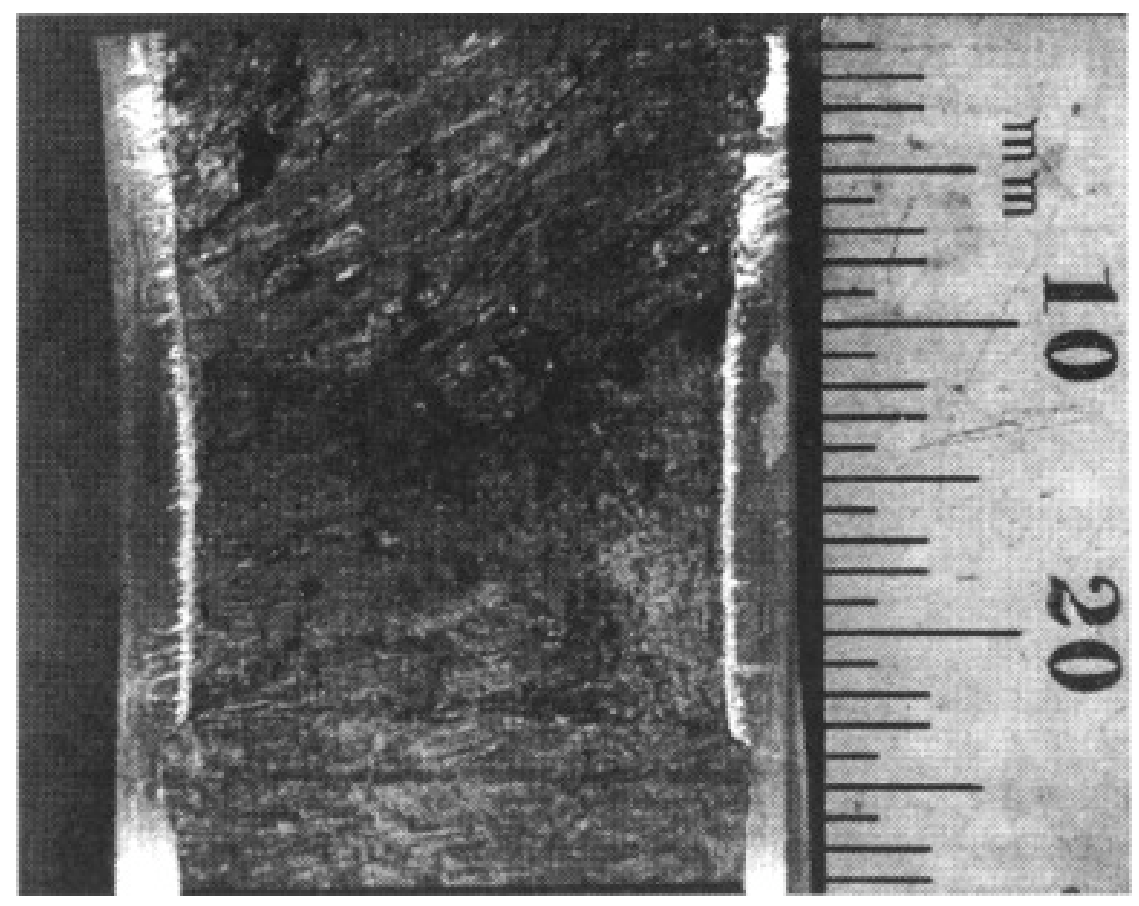

Figure A-13. Fracture surface of aged weld metal PWWO tested at $25^{\circ} \mathrm{C}$ 


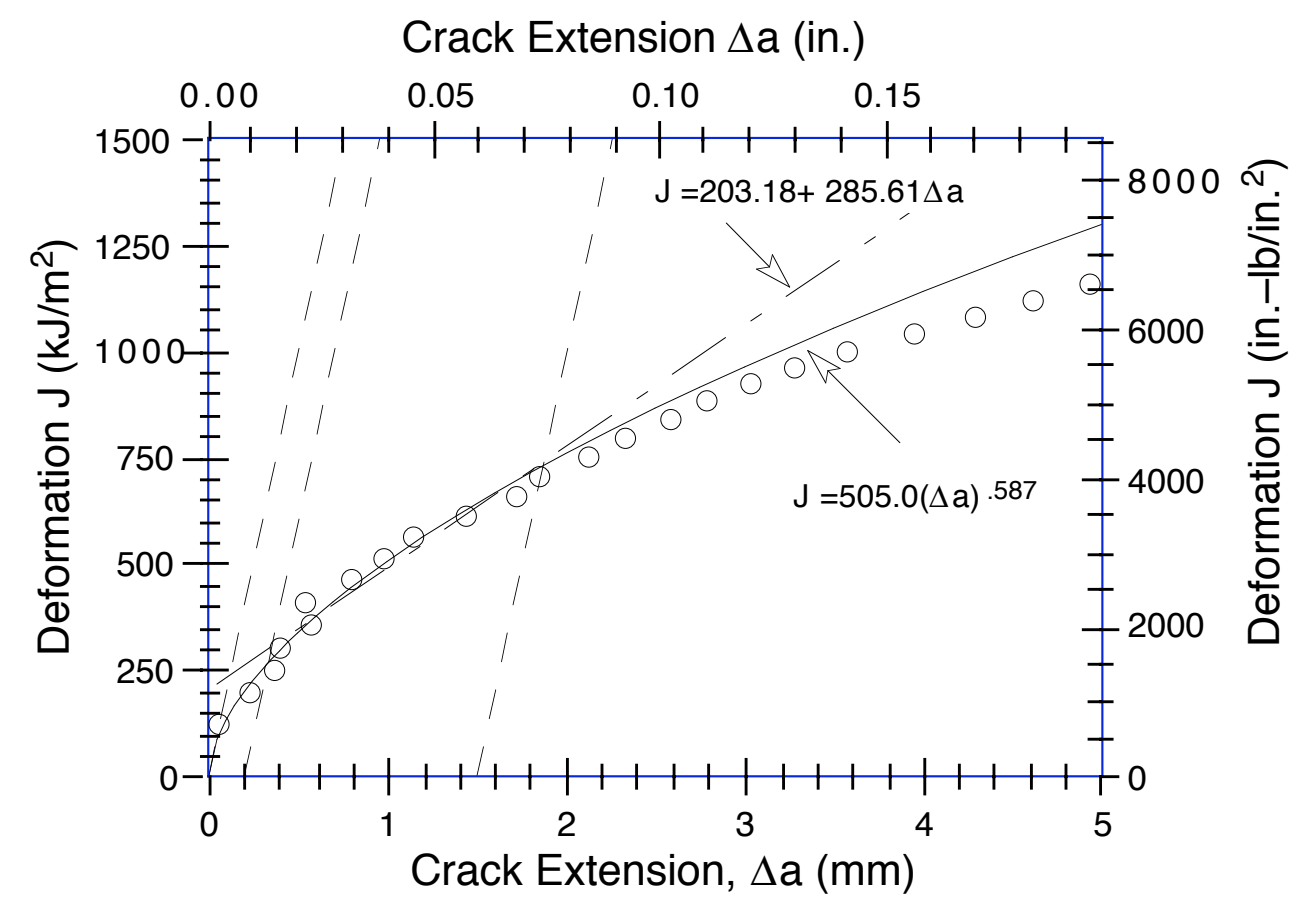

Figure A-14. Deformation J-R curve for weld metal specimen PWWO-03 aged at $400^{\circ} \mathrm{C}$ for $7,700 \mathrm{~h}$ and tested at $25^{\circ} \mathrm{C}$. Blunting, $0.2-\mathrm{mm}$ offset, and 1.5-mm offset lines are shown as dashed lines.

Crack Extension $\Delta \mathrm{a}$ (in.)

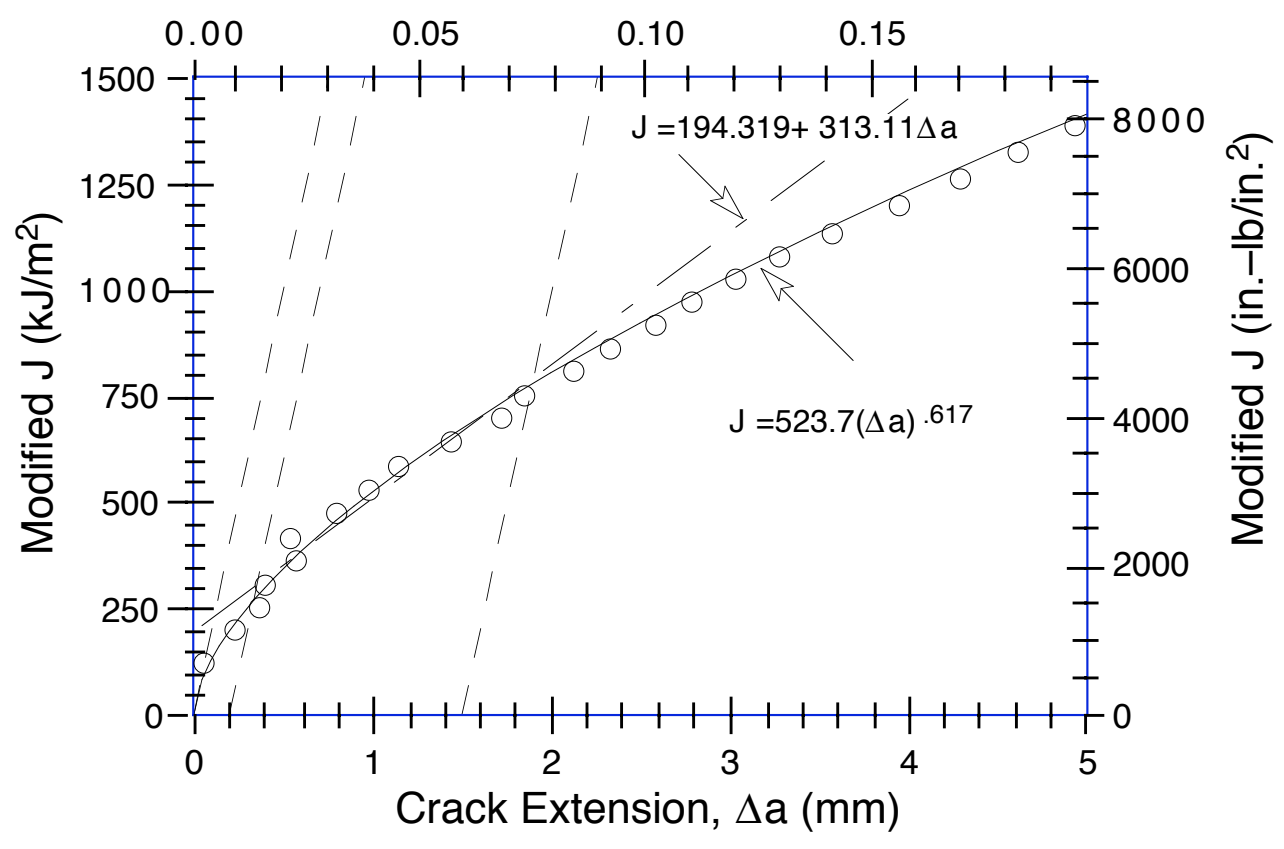

Figure A-15. Modified J-R curve for weld metal specimen PWWO-03 aged at $400^{\circ} \mathrm{C}$ for $7,700 \mathrm{~h}$ and tested at $25^{\circ} \mathrm{C}$. Blunting, 0.2- $\mathrm{mm}$ offset, and 1.5- $\mathrm{mm}$ offset lines are shown as dashed lines. 
Table A-16. Test data for specimen PWWO-01

$\begin{array}{llll}\text { Test Number } & : 0130 & \text { Test Temp } & : 290^{\circ} \mathrm{C} \\ \text { Material Type } & : \text { Weld Metal } & \text { Heat Number } & : \text { PWWO } \\ \text { Aging Temp } & : \text { Unaged } & \text { Aging Time } & :- \\ \text { Thickness } & : 22.80 \mathrm{~mm} & \text { Net Thickness } & : 18.25 \mathrm{~mm} \\ \text { Width } & : 50.77 \mathrm{~mm} & \text { Flow Stress } & : 398.00 \mathrm{MPa}\end{array}$

\begin{tabular}{|c|c|c|c|c|c|}
\hline $\begin{array}{l}\text { Unload } \\
\text { Number }\end{array}$ & $\begin{array}{c}J_{d} \\
\left(k J / m^{2}\right)\end{array}$ & $\begin{array}{c}J_{m} \\
\left(k J / m^{2}\right)\end{array}$ & $\begin{array}{c}\Delta \mathrm{a} \\
(\mathrm{m} \mathrm{m})\end{array}$ & $\begin{array}{l}\text { Load } \\
(k N)\end{array}$ & $\begin{array}{c}\text { Deflection } \\
(\mathrm{m} \mathrm{m})\end{array}$ \\
\hline 1 & 11.31 & 11.31 & -0.1395 & 16.399 & 0.252 \\
\hline 2 & 42.48 & 42.71 & 0.1499 & 27.040 & 0.503 \\
\hline 3 & 72.94 & 72.92 & 0.0260 & 31.755 & 0.704 \\
\hline 4 & 111.34 & 111.56 & 0.0861 & 34.229 & 0.905 \\
\hline 5 & 150.67 & 151.20 & 0.1372 & 35.577 & 1.107 \\
\hline 6 & 190.78 & 192.75 & 0.3069 & 36.325 & 1.307 \\
\hline 7 & 230.55 & 232.69 & 0.3223 & 36.468 & 1.508 \\
\hline 8 & 271.78 & 273.85 & 0.3170 & 36.555 & 1.707 \\
\hline 9 & 311.93 & 318.20 & 0.5812 & 36.638 & 1.906 \\
\hline 10 & 350.21 & 359.05 & 0.7222 & 36.527 & 2.109 \\
\hline 11 & 387.03 & 402.51 & 1.0406 & 35.650 & 2.309 \\
\hline 12 & 422.93 & 441.00 & 1.1521 & 35.176 & 2.507 \\
\hline 13 & 459.81 & 481.65 & 1.2985 & 34.566 & 2.704 \\
\hline 14 & 495.21 & 524.90 & 1.5760 & 34.166 & 2.910 \\
\hline 15 & 530.23 & 562.72 & 1.6671 & 33.686 & 3.108 \\
\hline 16 & 563.11 & 605.09 & 1.9535 & 33.057 & 3.308 \\
\hline 17 & 592.19 & 641.79 & 2.1692 & 32.554 & 3.498 \\
\hline 18 & 634.02 & 693.63 & 2. 4292 & 31.791 & 3.758 \\
\hline 19 & 671.71 & 741.77 & 2.6807 & 30.656 & 4.008 \\
\hline 20 & 706.29 & 789.59 & 2.9788 & 29.938 & 4.257 \\
\hline 21 & 732.25 & 836.18 & 3.4159 & 28.299 & 4.502 \\
\hline 22 & 762.66 & 880.74 & 3.6990 & 27.370 & 4.760 \\
\hline 23 & 779.00 & 925.36 & 4.2401 & 26.399 & 5.002 \\
\hline 24 & 801.04 & 966.62 & 4.5902 & 25.058 & 5.258 \\
\hline 25 & 822.81 & 1009.16 & 4.9525 & 24.656 & 5.509 \\
\hline 26 & 855.50 & 1048.02 & 5.0550 & 23.789 & 5.757 \\
\hline 27 & 872.31 & 1091.38 & 5.4786 & 23.123 & 5.998 \\
\hline 28 & 909.74 & 1138.25 & 5.6214 & 22.331 & 6.305 \\
\hline 29 & 933.26 & 1189.65 & 6.0237 & 21.622 & 6.606 \\
\hline 30 & 961.38 & 1235.25 & 6.2647 & 20.803 & 6.909 \\
\hline 31 & 970.18 & 1282.16 & 6.7711 & 19.680 & 7.203 \\
\hline 32 & 983.84 & 1324.77 & 7.1424 & 18.816 & 7.506 \\
\hline 33 & 1000.88 & 1367.54 & 7.4605 & 18.161 & 7.804 \\
\hline 34 & 1018.10 & 1410.95 & 7.7727 & 17.396 & 8.108 \\
\hline 35 & 1025.69 & 1468.22 & 8.3404 & 16.255 & 8.504 \\
\hline 36 & 1043.64 & 1519.40 & 8.7048 & 15.529 & 8.905 \\
\hline 37 & 1069.02 & 1571.89 & 8.9892 & 14.939 & 9.304 \\
\hline 38 & 1080.77 & 1625.23 & 9.4086 & 14.152 & 9.701 \\
\hline 39 & 1104.44 & 1673.77 & 9.6496 & 13.552 & 10.100 \\
\hline 40 & 1117.58 & 1724.96 & 10.0044 & 12.873 & 10.501 \\
\hline
\end{tabular}


Table A-17. Deformation J/C and J-R curve results for specimen PWWO-01

\begin{tabular}{|c|c|c|c|}
\hline Test Number & : 0130 & Test Temp & : $290^{\circ} \mathrm{C}$ \\
\hline Material Type & : Weld Metal & Heat Number & : PWWO \\
\hline Aging Temp & : Unaged & Aging Time & $:-$ \\
\hline Thickness & : $22.80 \mathrm{~mm}$ & Net Thickness & : $18.25 \mathrm{~mm}$ \\
\hline Width & : $50.77 \mathrm{~mm}$ & Flow Stress & : $398.00 \mathrm{MPa}$ \\
\hline Modulus E & $: 167.43 \mathrm{GPa}$ & (Effective) & \\
\hline Modulus E & $: 180.00 \mathrm{GPa}$ & (Nominal) & \\
\hline Init. Crack & : $29.0063 \mathrm{~mm}$ & Init. $a / w$ & : 0.5714 (Measured) \\
\hline Final Crack & : $39.8969 \mathrm{~mm}$ & Final a/w & : 0.7859 (Measured) \\
\hline Final Crack & : $39.0107 \mathrm{~mm}$ & Final a/w & : 0.7684 (Compliance) \\
\hline $\begin{array}{l}\text { Linear Fit } \\
\text { Intercept B } \\
\text { Fit Coeff. R } \\
J_{I C} \\
\Delta \text { a }\left(J_{I C}\right) \\
T \text { average }\end{array}$ & $\begin{array}{l}\mathbf{J}=\mathbf{B}+\mathbf{M}(\mathbf{\Delta} \mathbf{a}) \\
: 202.069 \mathrm{~kJ} / \mathrm{m}^{2} \\
: 0.9927 \\
: 229.8 \mathrm{~kJ} / \mathrm{m}^{2} \\
: 0.144 \mathrm{~mm} \\
: 202.9\end{array}$ & $\begin{array}{l}\text { Slope } M \\
(7 \text { Data Points }) \\
\left(1312.1 \text { in.-lb/in. }{ }^{2}\right) \\
(0.0057 \text { in.) } \\
\left(J_{I C} \text { at } 0.15\right)\end{array}$ & : $191.96 \mathrm{~kJ} / \mathrm{m}^{3}$ \\
\hline $\begin{array}{l}\text { Power-Law Fit } \\
\text { Coeff. C } \\
\text { Fit Coeff. R } \\
\mathrm{J}_{\mathrm{IC}}(0.20) \\
\Delta \mathrm{a}\left(\mathrm{J}_{\mathrm{IC}}\right) \\
\mathrm{T} \text { average } \\
\mathrm{J}_{\mathrm{IC}}(0.15) \\
\Delta \mathrm{a}\left(\mathrm{J}_{\mathrm{IC}}\right) \\
\mathrm{T} \text { average } \\
\mathrm{K}_{\mathrm{j} \mathrm{c}}\end{array}$ & $\begin{array}{l}\mathbf{J}=\mathbf{C}(\Delta \mathbf{a})^{\mathbf{n}} \\
: 400.91 \mathrm{~kJ} / \mathrm{m}^{2} \\
: 0.9883 \\
: 242.7 \mathrm{~kJ} / \mathrm{m}^{2} \\
: 0.352 \mathrm{~mm} \\
: 202.9 \\
: 220.4 \mathrm{~kJ} / \mathrm{m}^{2} \\
: 0.288 \mathrm{~mm} \\
: 207.7 \\
: 299.9 \mathrm{MPa}-\mathrm{m}^{0.5}\end{array}$ & $\begin{array}{l}\text { Exponent } n \\
(7 \text { Data Points) } \\
\left(1386.1 \text { in.-lb/in. }{ }^{2}\right) \\
(0.0139 \text { in.) } \\
\left(J_{I C} \text { at } 0.20\right) \\
\left(1258.6 \text { in.-lb/in. }{ }^{2}\right) \\
(0.0114 \text { in.) } \\
\left(J_{I C} \text { at } 0.15\right)\end{array}$ & 0.4812 \\
\hline $\begin{array}{l}J_{I C} \text { Validity \& Data } \\
J_{\text {max allowed }} \\
\text { Data Limit } \\
\Delta a \text { (max) allowed } \\
\text { Data Limit } \\
\text { Data Points } \\
\text { Data Point Spacing } \\
B_{\text {net and bo size }} \\
\text { dJ/da at } J_{I C} \\
a_{f} \text { Measurement } \\
\text { Initial crack shape } \\
\text { Crack size estimate } \\
\text { E Effective } \\
J_{I C} \text { Estimate }\end{array}$ & $\begin{array}{l}\text { Qualification (E } \mathbf{8 1 3} \\
: 577.39 \mathrm{~kJ} / \mathrm{m}^{2} \\
: \text { Jmax Ignored } \\
: 1.837 \mathrm{~mm} \\
: 1.5 \mathrm{Exclusion} \text { line } \\
: \text { Zone } \mathrm{A}=1 \\
: \text { OK } \\
: \text { OK } \\
: \text { OK } \\
: \text { Near-surface } \\
: \text { OK } \\
: \text { Inadequate } \\
: \text { OK } \\
: \text { Invalid }\end{array}$ & $\begin{array}{l}\text { 5) } \\
\left(J_{\max }=b_{o} \sigma f / 15\right) \\
\text { (at } 1.5 \text { exclusion line) } \\
\text { Zone } B=3\end{array}$ & \\
\hline $\begin{array}{l}\text { J-R curve Validity } \\
\text { Jmax allowed } \\
\Delta \text { a (max) allowed } \\
\Delta \text { a (max) allowed } \\
\text { Data Points } \\
\text { Data Point Spacing } \\
\text { J-R Curve Data }\end{array}$ & $\begin{array}{l}\text { \& Data Qualification } \\
: 363.08 \mathrm{~kJ} / \mathrm{m}^{2} \\
: 2.176 \mathrm{~mm} \\
: 4.457 \mathrm{~mm} \\
: \text { Zone A = } 7 \\
: \text { OK } \\
: \text { Invalid }\end{array}$ & $\begin{array}{l}\left(E \begin{array}{l}1152-86) \\
\left(J_{\max }=B_{\text {net }}\right.\end{array} \sigma_{f} / 20\right) \\
\left(\Delta \mathrm{a}=0.1 \mathrm{~b}_{\mathrm{o}}\right) \\
(\omega=5) \\
\text { Zone } \mathrm{B}=9\end{array}$ & \\
\hline
\end{tabular}


Table A-18. Modified JIC and J-R curve results for specimen PWWO-01

\begin{tabular}{|c|c|c|c|}
\hline $\begin{array}{l}\text { Linear Fit } \\
\text { Intercept B } \\
\text { Fit Coeff. R } \\
\mathrm{J}_{\mathrm{IC}} \\
\Delta \mathrm{a}\left(\mathrm{J}_{\mathrm{IC}}\right) \\
\mathrm{T} \text { average }\end{array}$ & $\begin{array}{l}\mathbf{J}=\mathbf{B}+\mathbf{M}(\mathbf{\Delta} \mathbf{a}) \\
: 193.262 \mathrm{~kJ} / \mathrm{m}^{2} \\
: 0.9939 \\
: 223.6 \mathrm{~kJ} / \mathrm{m}^{2} \\
: 0.140 \mathrm{~mm} \\
: 228.5\end{array}$ & $\begin{array}{l}\text { Slope M } \\
\text { (7 Data Points) } \\
(1276.9 \text { in.-lb/in. } 2) \\
(0.0055 \text { in.) } \\
\left(J_{I C} \text { at } 0.15\right)\end{array}$ & $: 216.13 \mathrm{~kJ} / \mathrm{m}^{3}$ \\
\hline $\begin{array}{l}\text { Power-Law Fit } \\
\text { Coeff. C } \\
\text { Fit Coeff. } \mathrm{R} \\
\mathrm{J}_{\mathrm{IC}}(0.20) \\
\Delta \mathrm{a}\left(\mathrm{J}_{\mathrm{IC}}\right) \\
\mathrm{T} \text { average } \\
\mathrm{J}_{\mathrm{IC}}(0.15) \\
\Delta \mathrm{a}\left(\mathrm{J}_{\mathrm{IC}}\right) \\
\mathrm{T} \text { average } \\
\mathrm{K}_{\mathrm{j}} \mathrm{C}\end{array}$ & 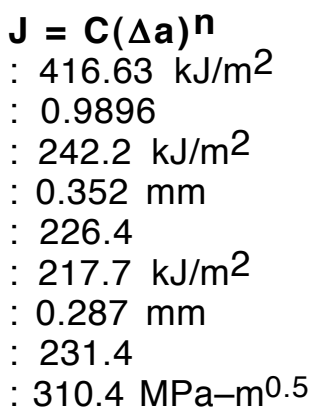 & $\begin{array}{l}\text { Exponent } n \\
(7 \text { Data Points) } \\
(1383.3 \text { in.-lb/in. } 2) \\
(0.0139 \text { in. }) \\
\left(J_{I C} \text { at } 0.20\right) \\
\left(1243.2 \text { in.-lb/in. }{ }^{2}\right) \\
(0.0113 \text { in. }) \\
\left(J_{I C} \text { at } 0.15\right)\end{array}$ & $: 0.5196$ \\
\hline
\end{tabular}

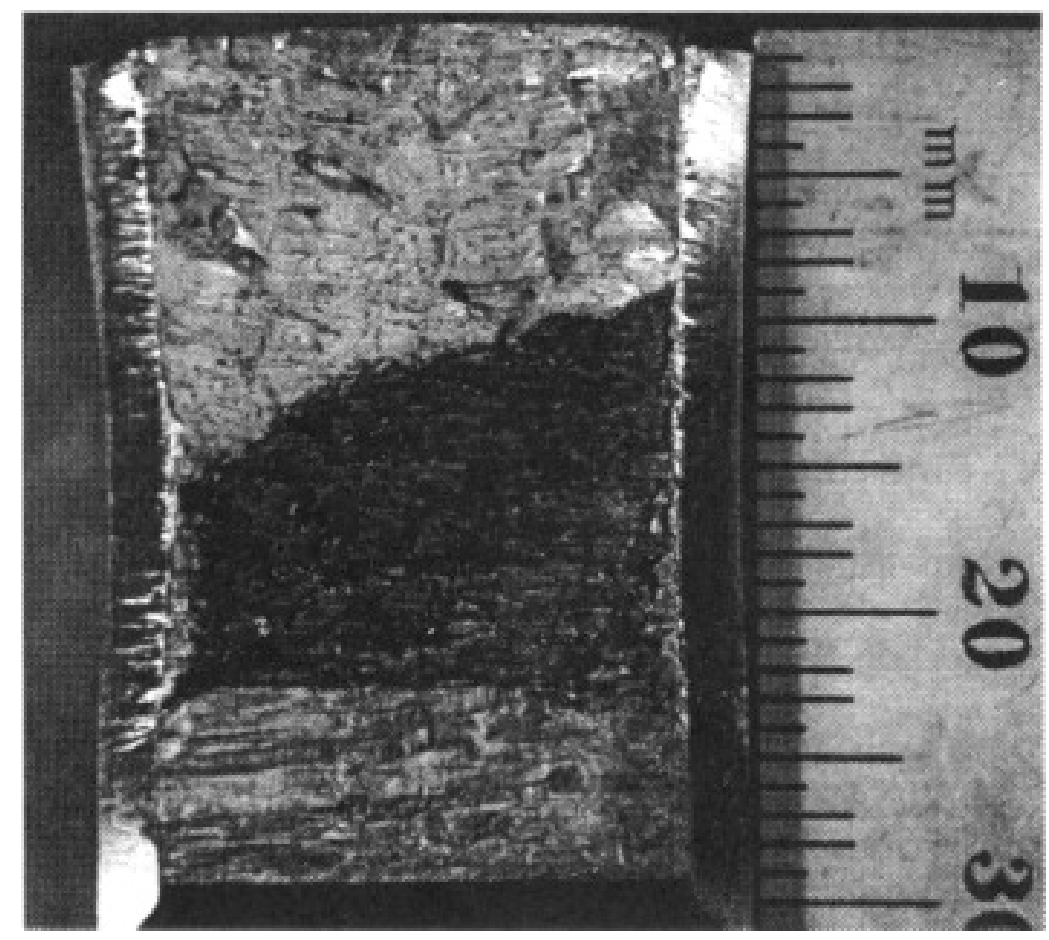

Figure A-16. Fracture surface of unaged weld metal PWWO tested at $290^{\circ} \mathrm{C}$ 


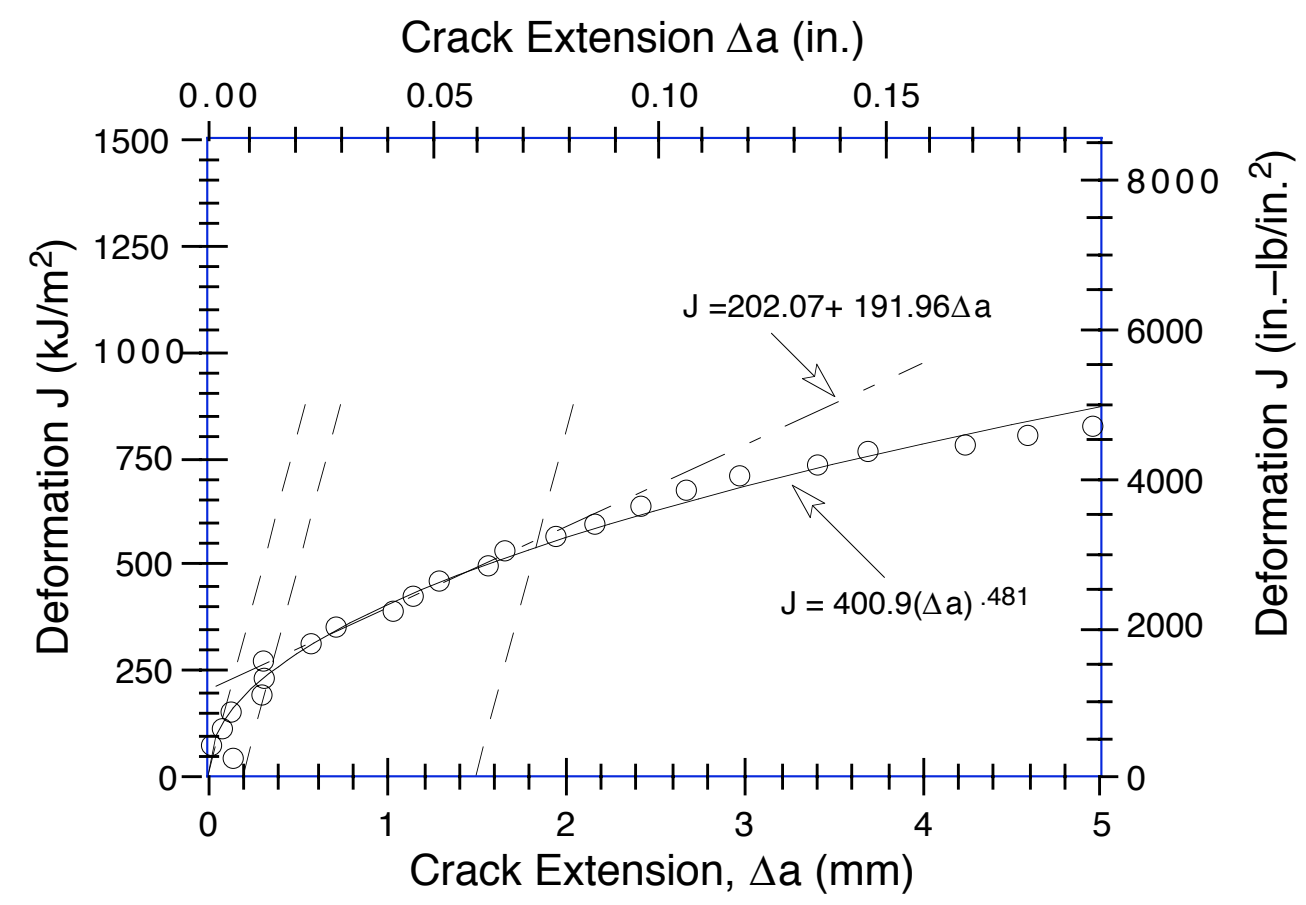

Figure $A-17$. Deformation $J-R$ curve for unaged weld metal specimen PWWO-01 tested at $290^{\circ} \mathrm{C}$. Blunting, 0.2- $\mathrm{mm}$ offset, and 1.5- $\mathrm{mm}$ offset lines are shown as dashed lines.

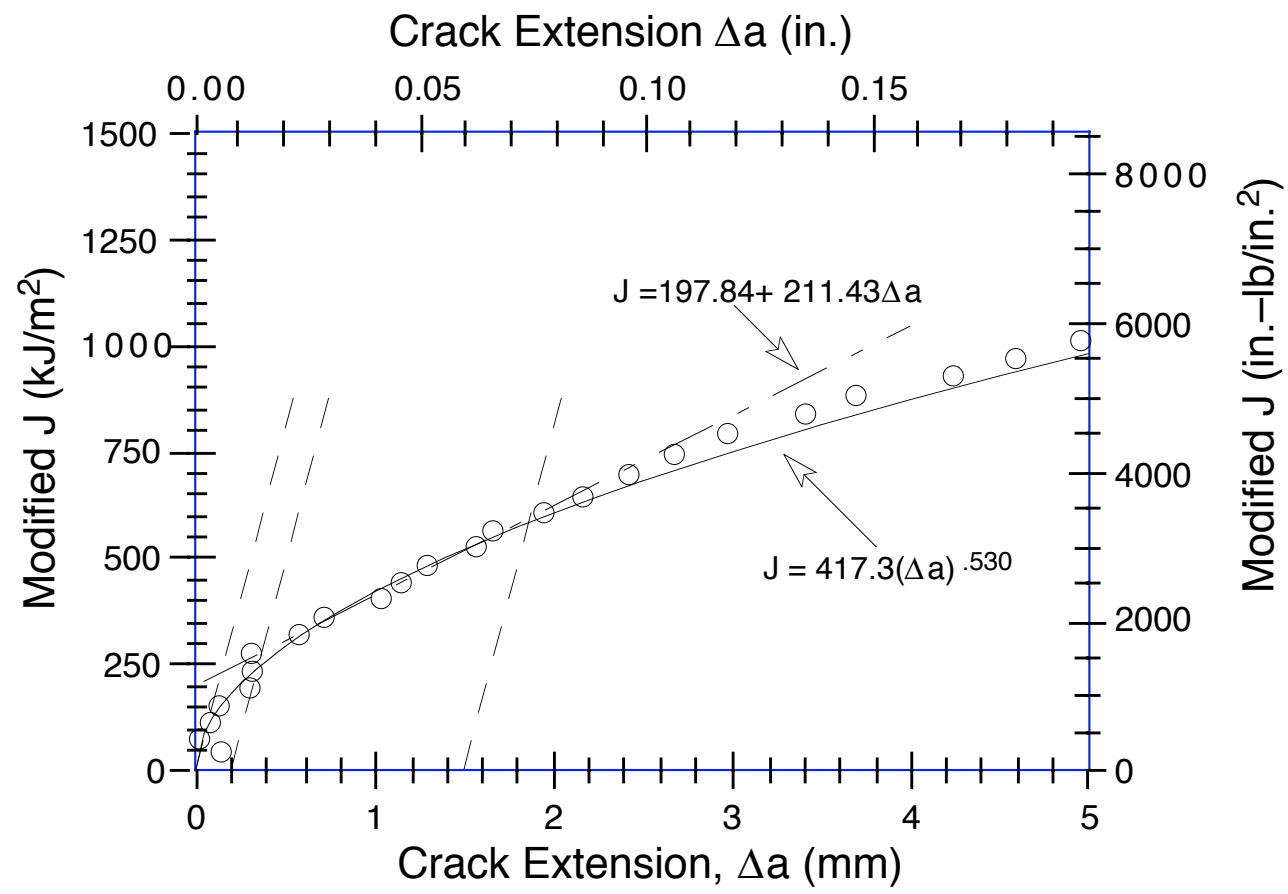

Figure A-18. Modified $J-R$ curve for unaged weld metal specimen PWWO-01 tested at $290^{\circ} \mathrm{C}$. Blunting, $0.2-\mathrm{mm}$ offset, and $1.5-\mathrm{mm}$ offset lines are shown as dashed lines. 
Table A-19. Test data for specimen PWWO-04

$\begin{array}{ll}\text { Test Number } & : 0128 \\ \text { Material Type } & : \text { Weld Metal } \\ \text { Aging Temp } & : 400^{\circ} \mathrm{C} \\ \text { Thickness } & : 22.85 \mathrm{~mm} \\ \text { Width } & : 50.81 \mathrm{~mm}\end{array}$

$\begin{array}{ll}\text { Test Temp } & : 290^{\circ} \mathrm{C} \\ \text { Heat Number } & : \text { PWWO } \\ \text { Aging Time } & : 7,700 \mathrm{~h} \\ \text { Net Thickness } & : 18.20 \mathrm{~mm} \\ \text { Flow Stress } & : 409.00 \mathrm{MPa}\end{array}$

\begin{tabular}{|c|c|c|c|c|c|}
\hline $\begin{array}{c}\text { Unload } \\
\text { Number }\end{array}$ & $\begin{array}{c}J_{d} \\
\left(k J / m^{2}\right)\end{array}$ & $\begin{array}{c}J_{m} \\
\left(k J / m^{2}\right)\end{array}$ & $\begin{array}{c}\Delta \mathrm{a} \\
(\mathrm{m} \mathrm{m})\end{array}$ & $\begin{array}{l}\text { Load } \\
(\mathrm{kN})\end{array}$ & $\begin{array}{c}\text { Deflection } \\
(\mathrm{mm})\end{array}$ \\
\hline $\begin{array}{l}1 \\
2 \\
3 \\
4 \\
5 \\
6 \\
7 \\
8 \\
9 \\
10 \\
11 \\
112 \\
13 \\
14 \\
15 \\
16 \\
17 \\
118 \\
19 \\
20 \\
21 \\
22 \\
23 \\
24 \\
25 \\
26 \\
26 \\
28 \\
29 \\
30 \\
31 \\
32 \\
33 \\
34\end{array}$ & $\begin{array}{r}13.40 \\
47.73 \\
92.07 \\
144.59 \\
193.78 \\
236.04 \\
287.38 \\
328.01 \\
366.71 \\
402.81 \\
435.56 \\
467.46 \\
497.52 \\
524.13 \\
549.66 \\
581.33 \\
607.64 \\
630.54 \\
644.64 \\
663.72 \\
682.90 \\
696.65 \\
716.78 \\
745.18 \\
772.28 \\
790.29 \\
797.59 \\
795.67 \\
808.74 \\
823.99 \\
821.26 \\
837.00 \\
856.34 \\
867.50\end{array}$ & $\begin{array}{r}13.40 \\
47.82 \\
91.74 \\
146.09 \\
196.10 \\
240.70 \\
294.25 \\
336.63 \\
382.05 \\
425.26 \\
468.56 \\
509.09 \\
551.59 \\
592.40 \\
630.37 \\
666.88 \\
710.43 \\
748.81 \\
784.94 \\
820.03 \\
853.66 \\
900.16 \\
938.28 \\
1007.55 \\
1068.00 \\
1128.74 \\
1184.41 \\
1236.86 \\
1299.16 \\
1358.76 \\
1417.30 \\
1468.40 \\
1522.71 \\
1577.34\end{array}$ & $\begin{array}{r}-0.0456 \\
0.0516 \\
-0.0899 \\
0.2313 \\
0.3302 \\
0.5459 \\
0.7041 \\
0.8106 \\
1.1671 \\
1.5010 \\
1.9490 \\
2.2816 \\
2.7202 \\
3.1849 \\
3.5639 \\
3.7014 \\
4.1601 \\
4.5476 \\
5.0753 \\
5.4390 \\
5.7522 \\
6.4259 \\
6.7777 \\
7.5163 \\
8.0774 \\
8.7521 \\
9.4739 \\
10.2483 \\
10.9049 \\
11.4612 \\
12.1900 \\
12.5876 \\
12.9590 \\
13.3962\end{array}$ & $\begin{array}{r}19.223 \\
31.277 \\
36.179 \\
38.228 \\
39.176 \\
39.512 \\
39.441 \\
39.193 \\
38.973 \\
38.061 \\
37.500 \\
36.304 \\
34.899 \\
33.871 \\
32.410 \\
31.862 \\
30.839 \\
29.376 \\
28.491 \\
26.850 \\
25.984 \\
24.490 \\
23.311 \\
21.719 \\
20.143 \\
18.615 \\
16.729 \\
15.274 \\
13.672 \\
12.533 \\
11.294 \\
10.347 \\
9.622 \\
8.848\end{array}$ & $\begin{array}{r}0.251 \\
0.502 \\
0.754 \\
1.006 \\
1.256 \\
1.459 \\
1.709 \\
1.907 \\
2.106 \\
2.309 \\
2.508 \\
2.707 \\
2.908 \\
3.110 \\
3.307 \\
3.506 \\
3.710 \\
3.918 \\
4.108 \\
4.314 \\
4.508 \\
4.757 \\
5.011 \\
5.408 \\
5.809 \\
6.207 \\
6.605 \\
7.006 \\
7.506 \\
8.006 \\
8.506 \\
9.006 \\
9.506 \\
10.022\end{array}$ \\
\hline
\end{tabular}


Table A-20. Deformation J/C and J-R curve results for specimen PWWO-04

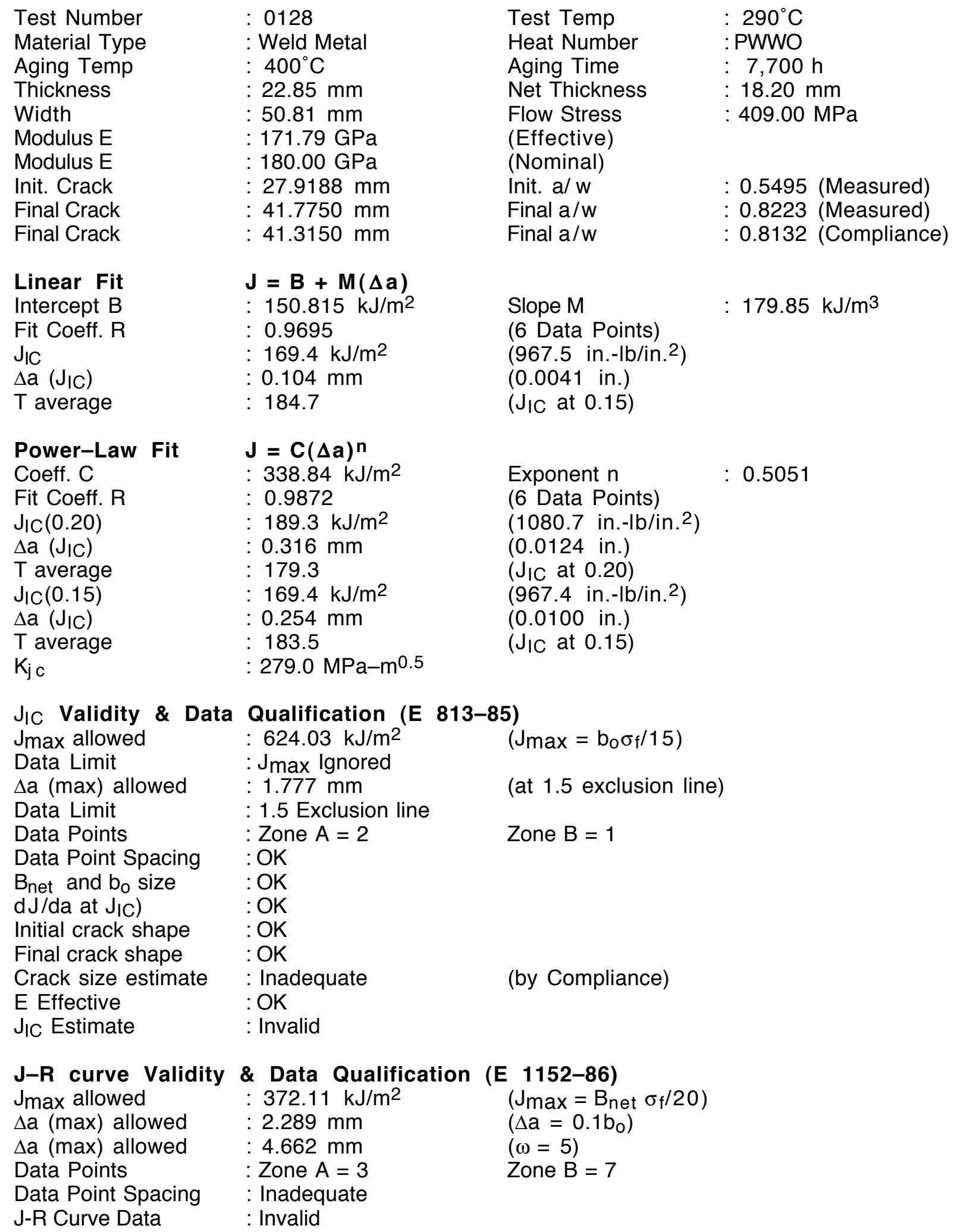


Table A-21. Modified J/C and J-R curve results for specimen PWWO-04

\begin{tabular}{|c|c|c|c|}
\hline $\begin{array}{l}\text { Linear Fit } \\
\text { Intercept B } \\
\text { Fit Coeff. R } \\
\mathrm{J}_{\mathrm{IC}} \\
\Delta \mathrm{a}\left(\mathrm{J}_{\mathrm{IC}}\right) \\
\mathrm{T} \text { average }\end{array}$ & $\begin{array}{l}\mathbf{J}=\mathbf{B}+\mathbf{M}(\mathbf{\Delta} \mathbf{a}) \\
: 146.094 \mathrm{~kJ} / \mathrm{m}^{2} \\
: 0.9763 \\
: 166.1 \mathrm{~kJ} / \mathrm{m}^{2} \\
: 0.102 \mathrm{~mm} \\
: 202.7\end{array}$ & 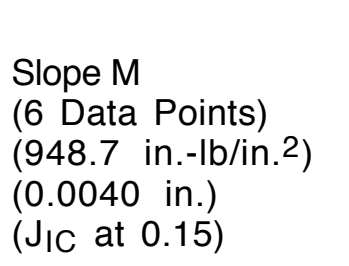 & $197.36 \mathrm{~kJ} / \mathrm{m}^{3}$ \\
\hline 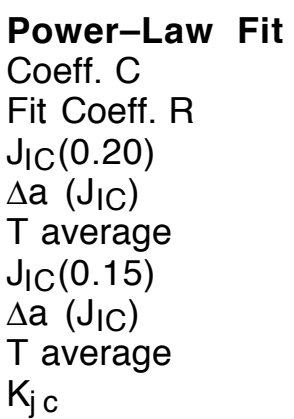 & $\begin{array}{l}\mathbf{J}=\mathbf{C}(\Delta \mathbf{a}) \mathbf{n} \\
: 351.67 \mathrm{~kJ} / \mathrm{m}^{2} \\
: 0.9897 \\
: 190.6 \mathrm{~kJ} / \mathrm{m}^{2} \\
: 0.316 \mathrm{~mm} \\
: 195.1 \\
: 169.4 \mathrm{~kJ} / \mathrm{m}^{2} \\
: 0.254 \mathrm{~mm} \\
: 199.4 \\
: 287.1 \mathrm{MPa}-\mathrm{m}^{0.5}\end{array}$ & $\begin{array}{l}\text { Exponent } n \\
(6 \text { Data Points) } \\
\left(1088.3 \text { in.-lb/in. }{ }^{2}\right) \\
(0.0125 \text { in. }) \\
\left(\mathrm{J}_{\mathrm{IC}} \text { at } 0.20\right) \\
\left(967.0 \text { in.-lb/in. }{ }^{2}\right) \\
(0.0100 \mathrm{in} .) \\
(\mathrm{JIC} \text { at } 0.15)\end{array}$ & 0.5325 \\
\hline
\end{tabular}

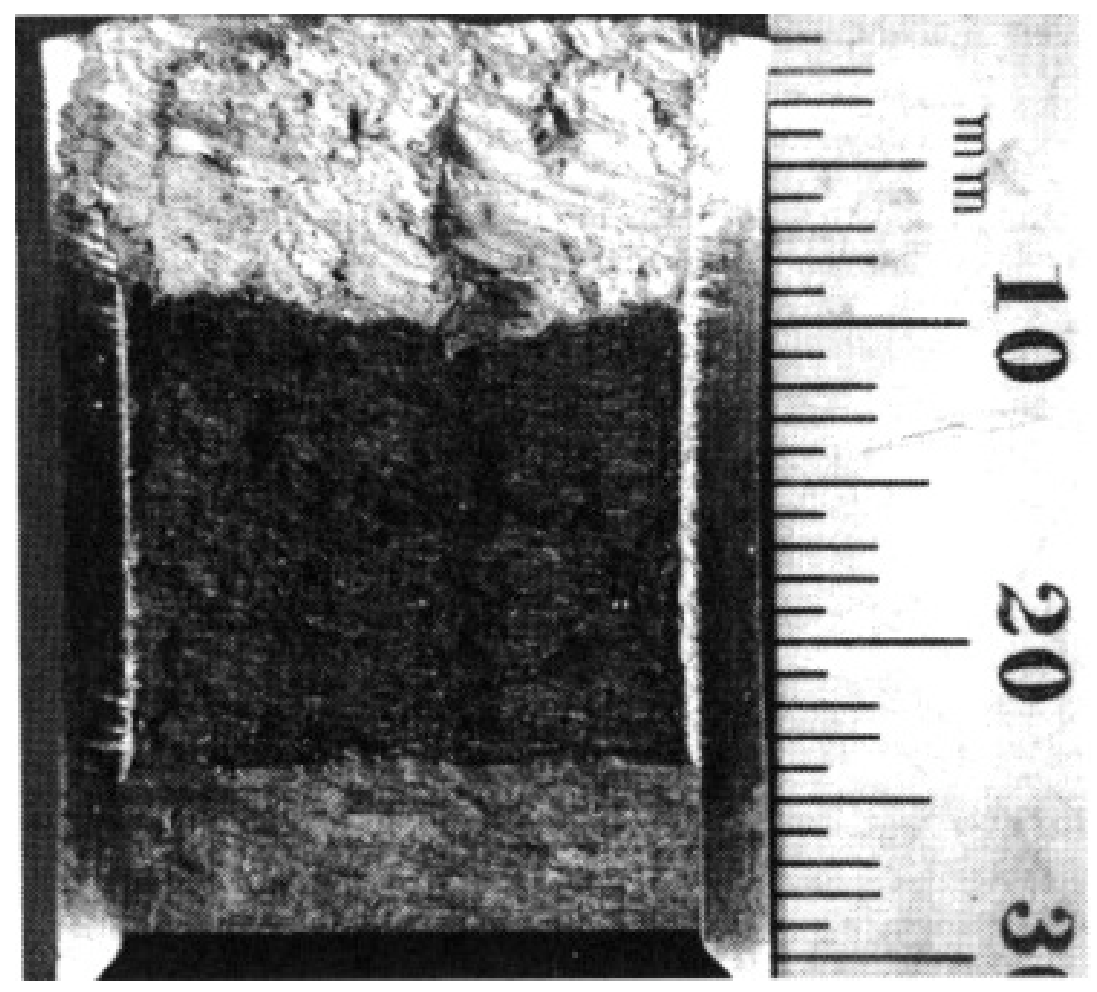

Figure A-19. Fracture surface of aged weld metal PWWO tested at $290^{\circ} \mathrm{C}$ 


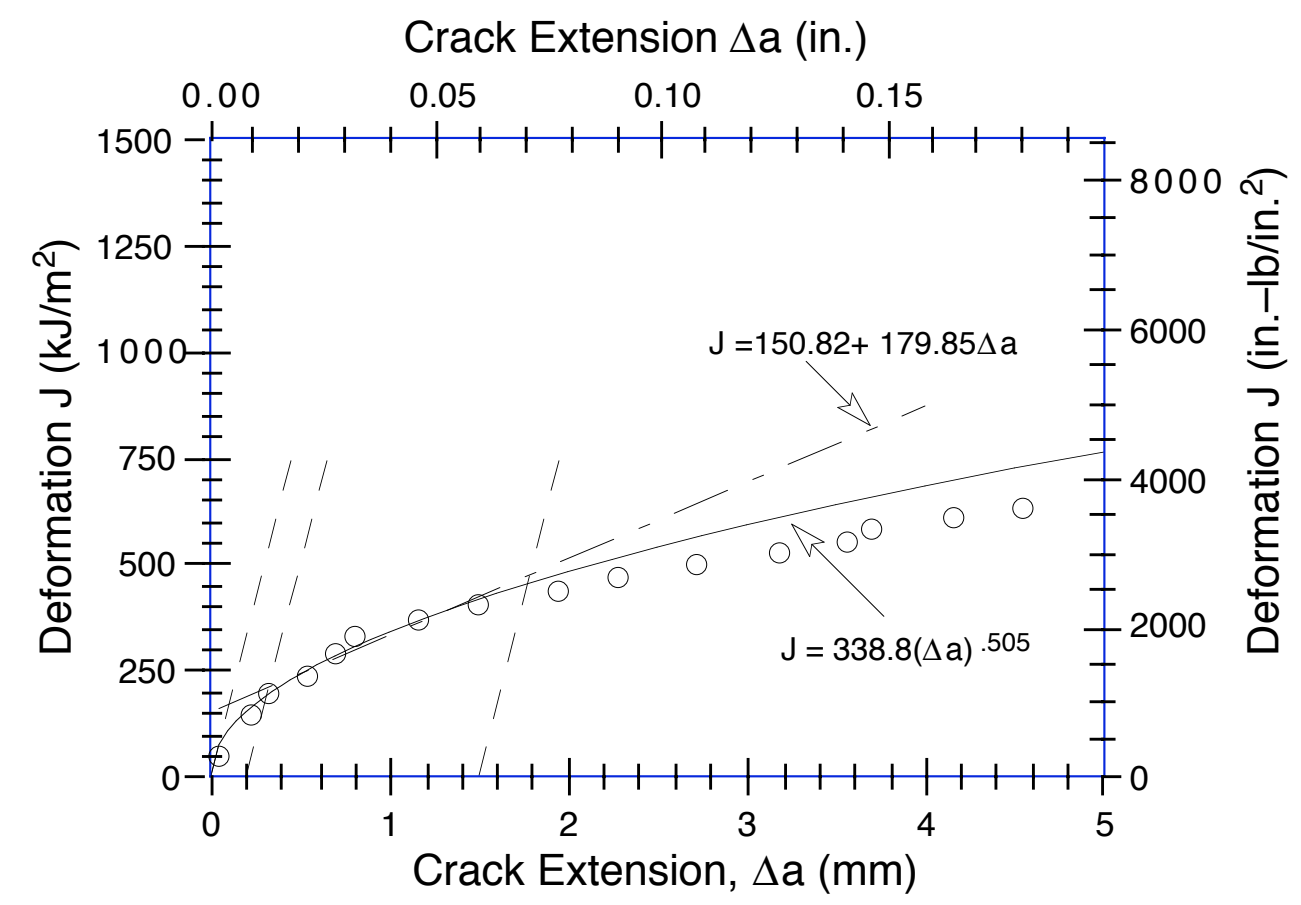

Figure A-20. Deformation J-R curve for weld metal specimen PWWO-04 aged at $400^{\circ} \mathrm{C}$ for $7,700 \mathrm{~h}$ and tested at $290^{\circ} \mathrm{C}$. Blunting, 0.2-mm offset, and 1.5-mm offset lines are shown as dashed lines.

Crack Extension $\Delta \mathrm{a}$ (in.)

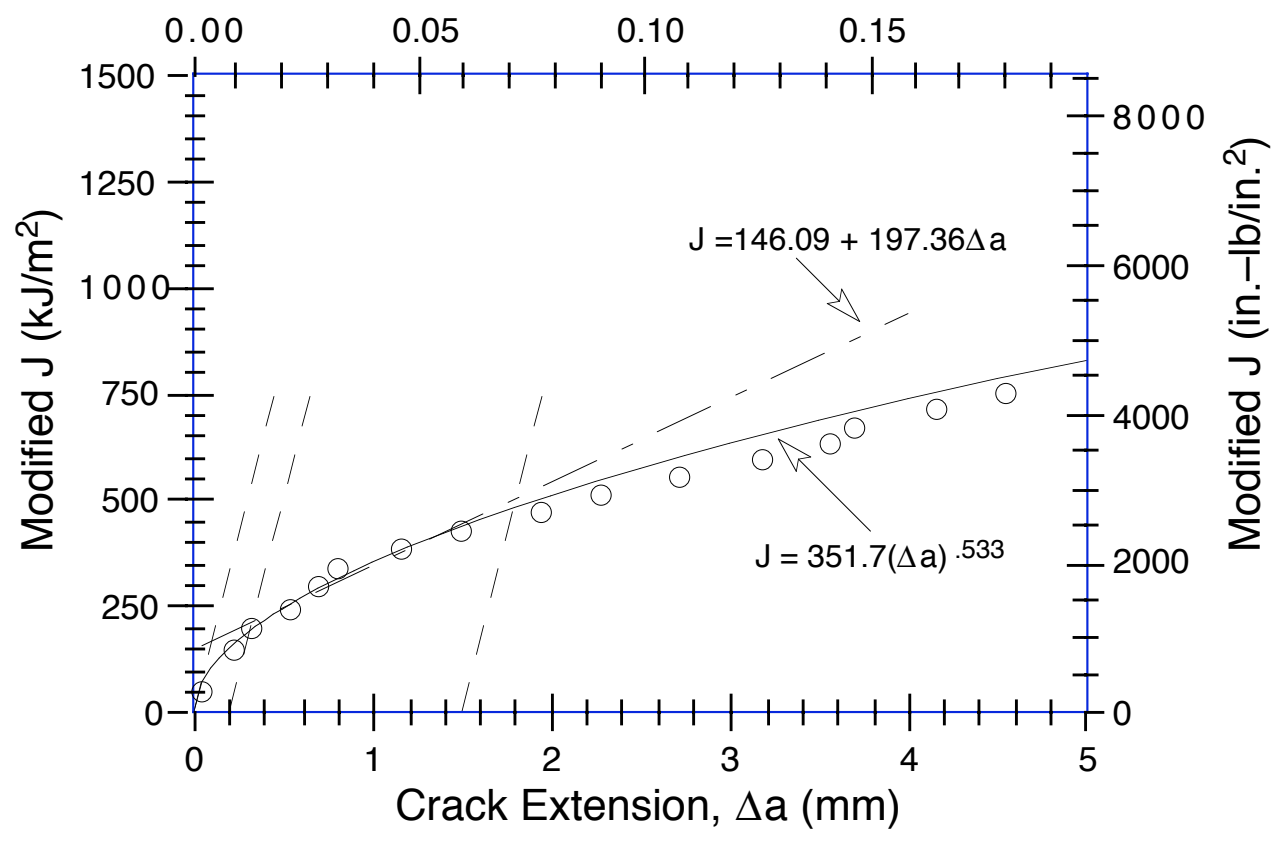

Figure A-21. Modified J-R curve for weld metal specimen PWWO-04 aged at $400^{\circ} \mathrm{C}$ for $7,700 \mathrm{~h}$ and tested at $290^{\circ} \mathrm{C}$. Blunting, 0.2- $\mathrm{mm}$ offset, and 1.5-mm offset lines are shown as dashed lines. 
Table A-22. Test data for specimen PWWO-02

$\begin{array}{ll}\text { Test Number } & : 0126 \\ \text { Material Type } & : \text { Weld Metal } \\ \text { Aging Temp } & : 400^{\circ} \mathrm{C} \\ \text { Thickness } & : 22.84 \mathrm{~mm} \\ \text { Width } & : 50.75 \mathrm{~mm}\end{array}$

$\begin{array}{ll}\text { Test Temp } & : 290^{\circ} \mathrm{C} \\ \text { Heat Number } & : \text { PWWO } \\ \text { Aging Time } & : 7,700 \mathrm{~h} \\ \text { Net Thickness } & : 18.25 \mathrm{~mm} \\ \text { Flow Stress } & : 409.00 \mathrm{MPa}\end{array}$

\begin{tabular}{crrrrr}
\hline $\begin{array}{c}\text { Unload } \\
\text { Number }\end{array}$ & $\begin{array}{c}J_{\mathrm{d}} \\
\left(\mathrm{kJ} / \mathrm{m}^{2}\right)\end{array}$ & $\begin{array}{c}J_{\mathrm{m}} \\
\left(\mathrm{kJ} / \mathrm{m}^{2}\right)\end{array}$ & $\begin{array}{c}\Delta \mathrm{a} \\
(\mathrm{m} \mathrm{m})\end{array}$ & $\begin{array}{c}\text { Load } \\
(\mathrm{kN})\end{array}$ & $\begin{array}{c}\text { Deflection } \\
(\mathrm{m} \mathrm{m})\end{array}$ \\
\hline & & & & & \\
1 & 13.54 & 13.54 & 0.0195 & 18.816 & 0.251 \\
2 & 46.86 & 46.92 & 0.0824 & 29.863 & 0.502 \\
3 & 104.46 & 104.16 & -0.0157 & 35.332 & 0.826 \\
4 & 141.63 & 143.09 & 0.2938 & 36.521 & 1.006 \\
5 & 190.13 & 192.42 & 0.3915 & 37.441 & 1.257 \\
6 & 245.43 & 251.61 & 0.7218 & 37.577 & 1.528 \\
7 & 280.46 & 284.68 & 0.5809 & 37.735 & 1.707 \\
8 & 321.85 & 331.83 & 0.9298 & 37.440 & 1.904 \\
9 & 358.97 & 373.42 & 1.1657 & 37.215 & 2.108 \\
10 & 396.27 & 415.94 & 1.4102 & 36.676 & 2.308 \\
11 & 428.64 & 460.78 & 1.9358 & 36.078 & 2.510 \\
12 & 464.21 & 495.68 & 1.9102 & 35.242 & 2.708 \\
13 & 502.69 & 541.39 & 2.1608 & 34.758 & 2.911 \\
14 & 536.61 & 582.55 & 2.3914 & 33.899 & 3.113 \\
15 & 563.10 & 624.27 & 2.8438 & 32.901 & 3.310 \\
16 & 574.73 & 665.58 & 3.6785 & 31.035 & 3.509 \\
17 & 599.36 & 694.23 & 3.7855 & 30.069 & 3.706 \\
18 & 627.89 & 735.82 & 4.1106 & 29.032 & 3.910 \\
19 & 647.42 & 773.49 & 4.5391 & 28.000 & 4.109 \\
20 & 666.73 & 808.84 & 4.9003 & 27.134 & 4.310 \\
21 & 676.77 & 845.08 & 5.4653 & 25.673 & 4.506 \\
22 & 696.31 & 887.41 & 5.9308 & 24.324 & 4.761 \\
23 & 700.25 & 930.89 & 6.7034 & 22.719 & 5.009 \\
24 & 723.90 & 993.49 & 7.4071 & 20.493 & 5.411 \\
25 & 733.33 & 1052.86 & 8.2530 & 18.355 & 5.807 \\
26 & 744.51 & 1107.26 & 8.9417 & 16.557 & 6.213 \\
27 & 750.04 & 1158.83 & 9.6365 & 15.031 & 6.606 \\
28 & 763.97 & 1207.24 & 10.1289 & 13.918 & 7.005 \\
29 & 775.01 & 1270.72 & 10.8293 & 12.507 & 7.506 \\
30 & 775.96 & 1326.60 & 11.5211 & 10.970 & 8.005 \\
31 & 779.86 & 1378.73 & 12.0967 & 9.975 & 8.507 \\
32 & 786.84 & 1429.87 & 12.5959 & 9.114 & 9.014 \\
33 & 792.04 & 1478.72 & 13.0649 & 8.398 & 9.510 \\
34 & 776.02 & 1527.03 & 13.7284 & 7.734 & 10.007 \\
& & & & & \\
\hline & & & & &
\end{tabular}


Table A-23. Deformation J/C and J-R curve results for specimen PWWO-02

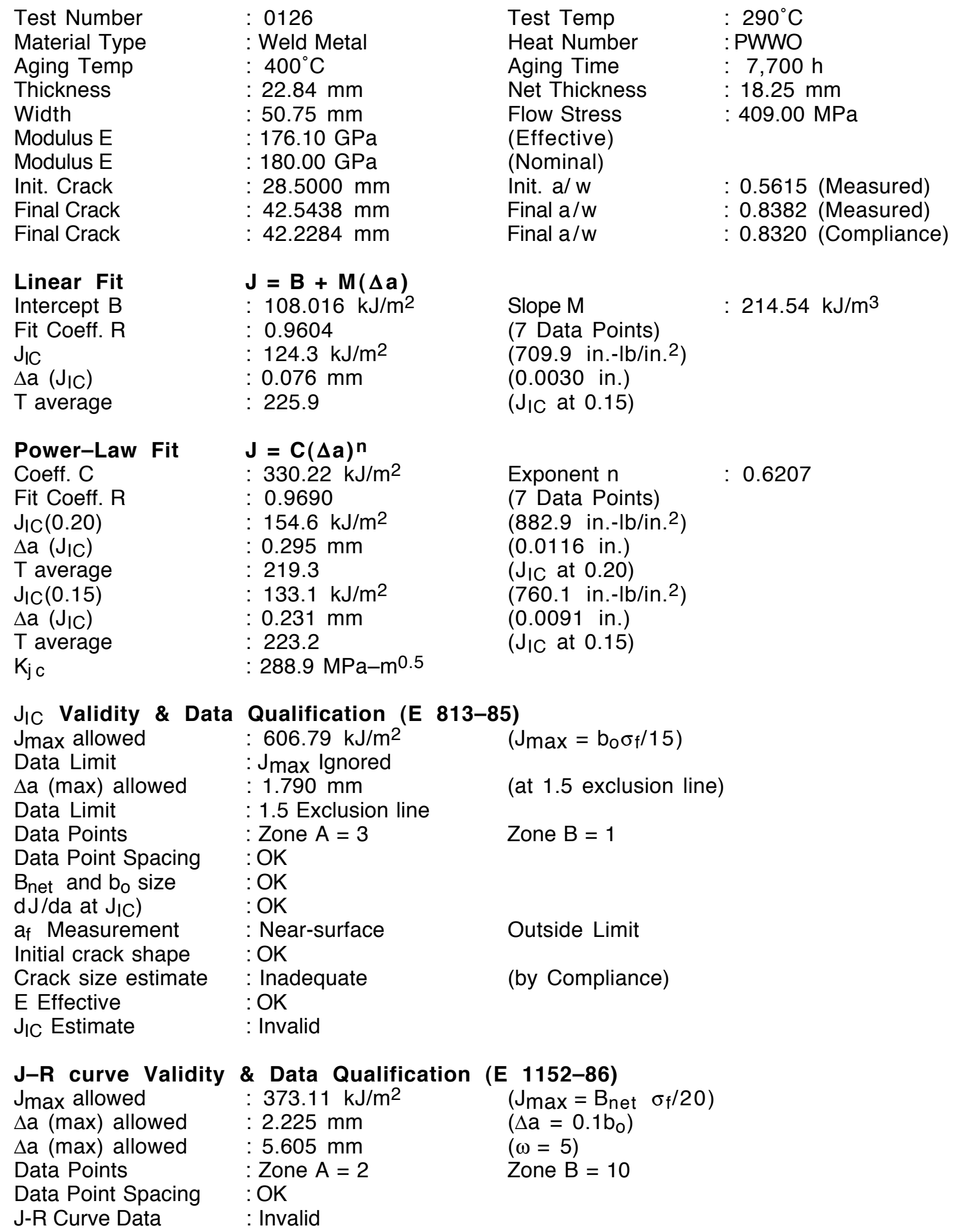


Table A-24. Modified JIC and J-R curve results for specimen PWWO-02

\begin{tabular}{|c|c|c|c|}
\hline $\begin{array}{l}\text { Linear Fit } \\
\text { Intercept B } \\
\text { Fit Coeff. R } \\
\mathrm{J}_{\mathrm{IC}} \\
\Delta \mathrm{a}\left(\mathrm{J}_{\mathrm{IC}}\right) \\
\mathrm{T} \text { average }\end{array}$ & $\begin{array}{l}\mathbf{J}=\mathbf{B}+\mathbf{M}(\Delta \mathbf{a}) \\
: 103.460 \mathrm{~kJ} / \mathrm{m}^{2} \\
: 0.9668 \\
: 120.5 \mathrm{~kJ} / \mathrm{m}^{2} \\
: 0.074 \mathrm{~mm} \\
: 243.1\end{array}$ & $\begin{array}{l}\text { Slope M } \\
\text { ( } 7 \text { Data Points) } \\
\left(687.9 \text { in.-lb/in. }{ }^{2}\right) \\
(0.0029 \text { in. }) \\
\left(J_{I C} \text { at } 0.15\right)\end{array}$ & $230.95 \mathrm{~kJ} / \mathrm{m}^{3}$ \\
\hline 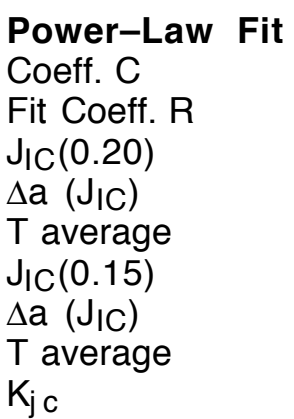 & $\begin{array}{l}\mathbf{J}=\mathbf{C}(\Delta \mathbf{a})^{\mathbf{n}} \\
: 341.93 \mathrm{~kJ} / \mathrm{m}^{2} \\
: 0.9730 \\
: 155.6 \mathrm{~kJ} / \mathrm{m}^{2} \\
: 0.295 \mathrm{~mm} \\
: 234.9 \\
: 133.0 \mathrm{~kJ} / \mathrm{m}^{2} \\
: 0.231 \mathrm{~mm} \\
: 238.9 \\
: 296.9 \mathrm{MPa}-\mathrm{m}^{0.5}\end{array}$ & $\begin{array}{l}\text { Exponent } \mathrm{n} \\
(7 \text { Data Points) } \\
\left(888.6 \text { in.-lb/in. }{ }^{2}\right) \\
(0.0116 \text { in. }) \\
\left(J_{I C} \text { at } 0.20\right) \\
\left(759.3 \text { in.-lb/in. }{ }^{2}\right) \\
(0.0091 \text { in. }) \\
\left(J_{I C} \text { at } 0.15\right)\end{array}$ & 0.6451 \\
\hline
\end{tabular}

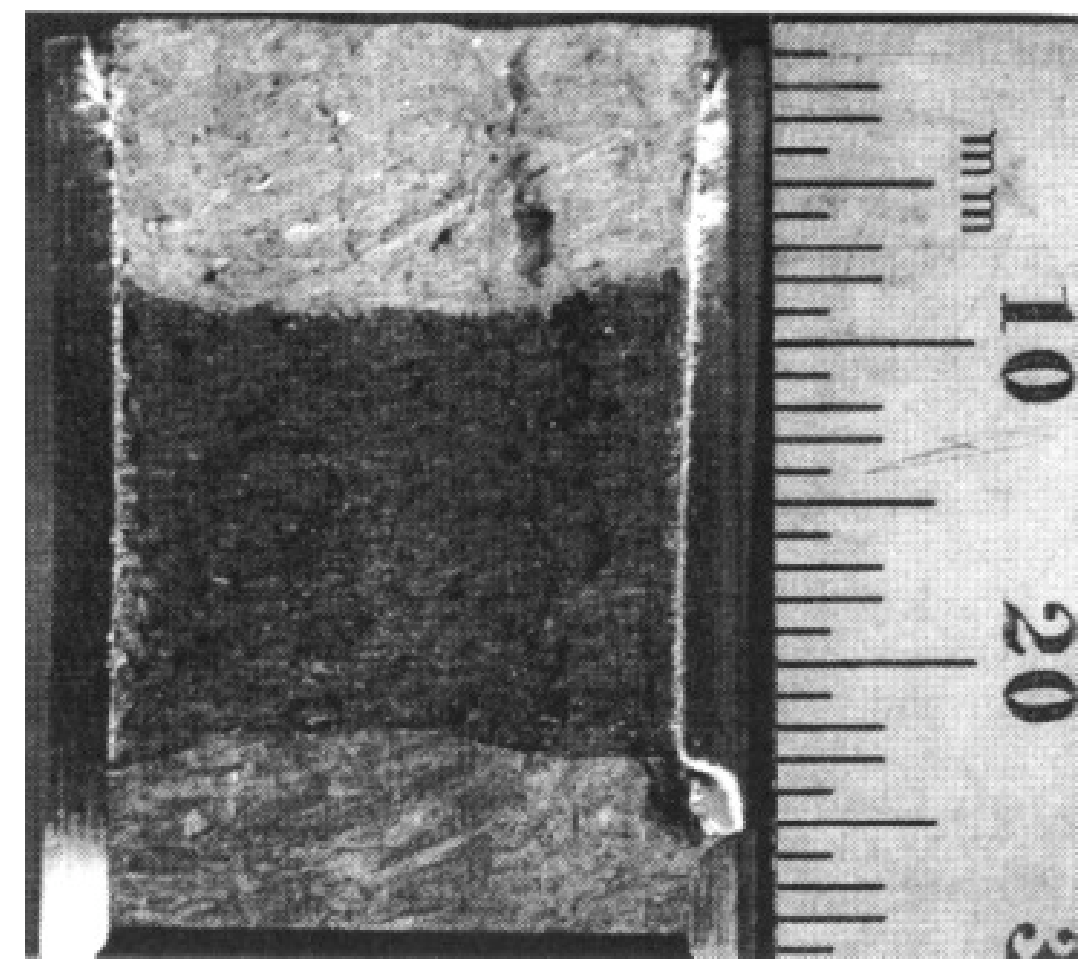

Figure A-22. Fracture surface of aged weld metal PWWO tested at $290^{\circ} \mathrm{C}$ 


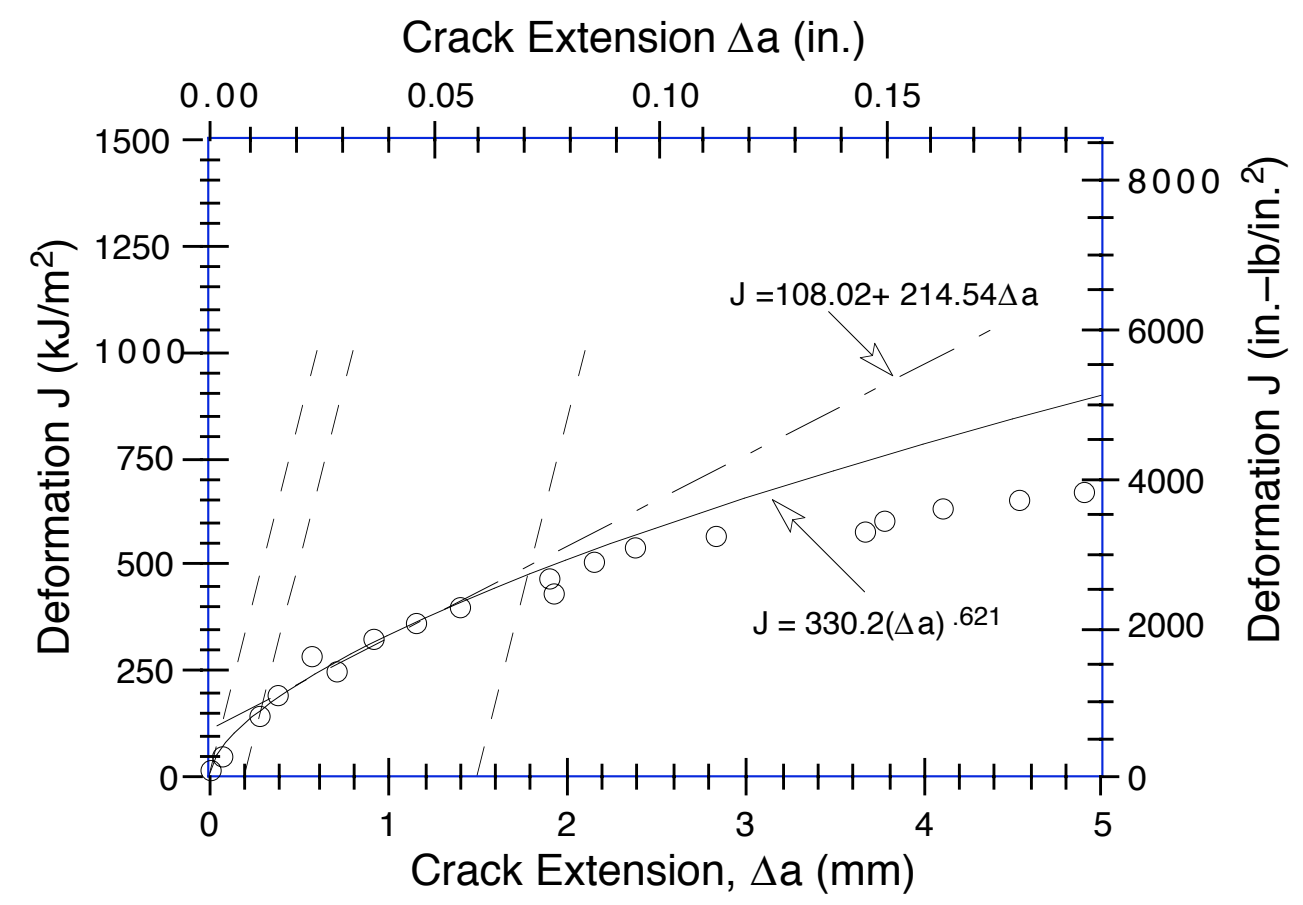

Figure A-23. Deformation J-R curve for weld metal specimen PWWO-02 aged at $400^{\circ} \mathrm{C}$ for $7,700 \mathrm{~h}$ and tested at $290^{\circ} \mathrm{C}$. Blunting, 0.2- $\mathrm{mm}$ offset, and 1.5-mm offset lines are shown as dashed lines.

Crack Extension $\Delta \mathrm{a}$ (in.)

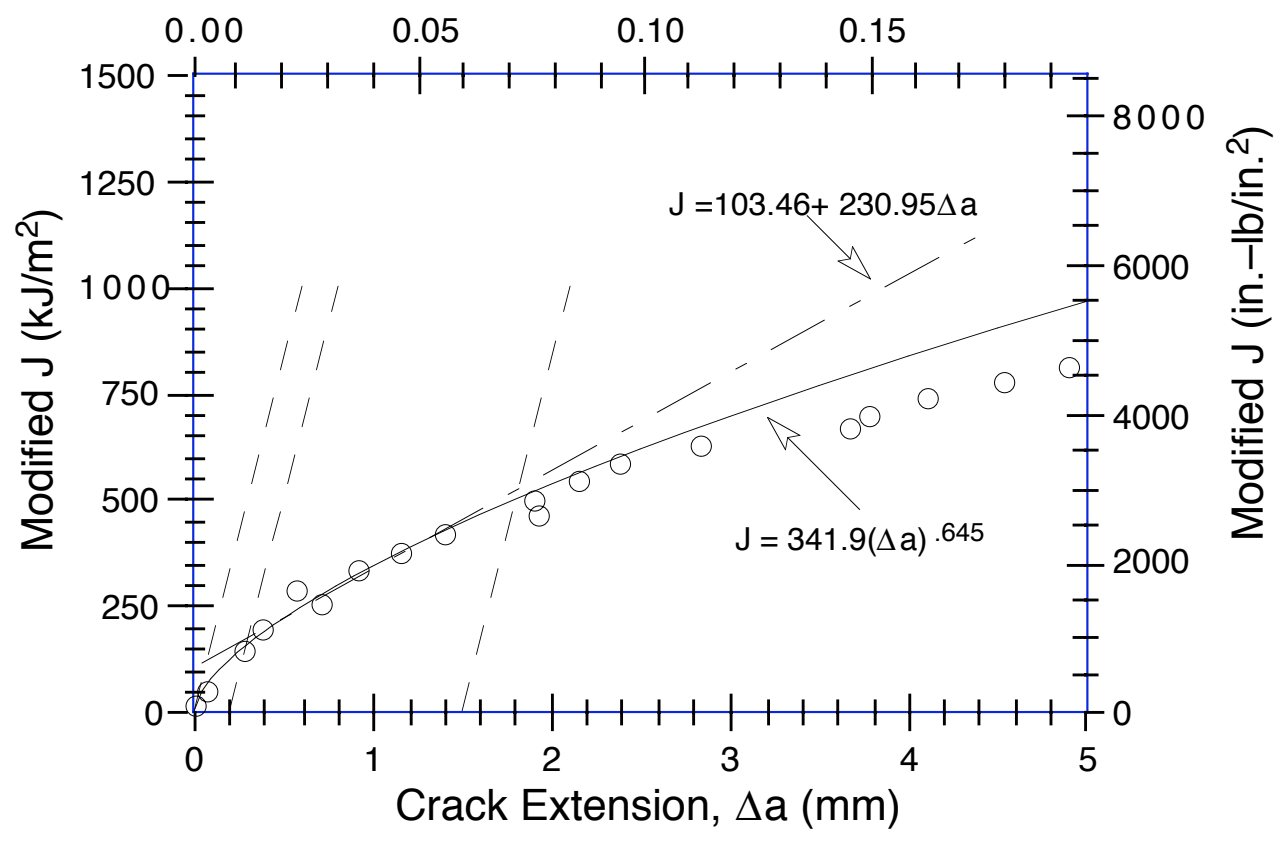

Figure A-24. Modified J-R curve for weld metal specimen PWWO-02 aged at $400^{\circ} \mathrm{C}$ for $7,700 \mathrm{~h}$ and tested at $290^{\circ} \mathrm{C}$. Blunting, 0.2- $\mathrm{mm}$ offset, and 1.5-mm offset lines are shown as dashed lines. 
Table A-25. Test data for specimen PWER-01

\begin{tabular}{|c|c|c|c|c|c|}
\hline $\begin{array}{l}\text { Test Nun } \\
\text { Material } \\
\text { Aging Te } \\
\text { Thicknes } \\
\text { Width }\end{array}$ & $\begin{array}{l}\text { ber } \\
\text { ype } \\
\text { np }\end{array}$ & $\begin{array}{l}\text { Metal } \\
\mathrm{C} \\
3 \mathrm{~mm} \\
\mathrm{~mm}\end{array}$ & $\begin{array}{l}\text { Test } \\
\text { Heat } \\
\text { Aging } \\
\text { Net T } \\
\text { Flow }\end{array}$ & & $\begin{array}{l}\mathrm{C} \\
00 \mathrm{~h} \\
0 \mathrm{~mm} \\
0 \mathrm{MPa}\end{array}$ \\
\hline $\begin{array}{c}\text { Unload } \\
\text { Number }\end{array}$ & $\begin{array}{c}J_{d} \\
\left(k J / m^{2}\right)\end{array}$ & $\begin{array}{c}J_{m} \\
\left(k J / m^{2}\right)\end{array}$ & $\begin{array}{c}\Delta \mathrm{a} \\
(\mathrm{m} \mathrm{m})\end{array}$ & $\begin{array}{l}\text { Load } \\
(\mathrm{kN})\end{array}$ & $\begin{array}{c}\text { Deflection } \\
(\mathrm{m} \mathrm{m})\end{array}$ \\
\hline 1 & 12.77 & 12.78 & 0.1408 & 20.967 & 0.251 \\
\hline 2 & 35.40 & 35.22 & -0.1580 & 31.170 & 0.442 \\
\hline 3 & 63.39 & 63.48 & -0.0061 & 35.990 & 0.602 \\
\hline 4 & 91.23 & 91.75 & 0.1304 & 38.466 & 0.760 \\
\hline 5 & 127.66 & 127.64 & 0.0252 & 40.155 & 0.957 \\
\hline 6 & $\begin{array}{l}198.54 \\
\end{array}$ & $\begin{array}{l}199.40 \\
\text {. }\end{array}$ & 0.1229 & 41.692 & 1.306 \\
\hline 7 & 279.37 & 283.71 & 0.3753 & 42.390 & 1.707 \\
\hline 8 & 360.83 & 365.44 & 0.3895 & 42.499 & 2.107 \\
\hline 9 & 437.53 & 455.32 & 0.9520 & 42.220 & 2.508 \\
\hline 10 & 512.00 & 535.78 & $\begin{array}{l}1.1642 \\
1.0\end{array}$ & 41.331 & 2.907 \\
\hline 11 & 583.66 & 622.77 & 1.6278 & 40.579 & 3.310 \\
\hline 12 & 647.88 & 704.84 & 2.1016 & 39.436 & 3.706 \\
\hline 13 & 718.76 & 785.96 & 2.3418 & 38.515 & 4.110 \\
\hline 14 & 771.03 & 871.84 & 3.0574 & 37.640 & 4.507 \\
\hline 15 & 841.60 & 945.24 & 3.1118 & 36.280 & 4.908 \\
\hline 16 & 896.63 & 1029.82 & 3.6325 & 34.991 & 5.307 \\
\hline 17 & 950.21 & 1106.43 & 4.0083 & 33.939 & 5.708 \\
\hline 18 & 997.64 & 1184.50 & 4.4740 & 32.668 & 6.108 \\
\hline 19 & 1048.57 & 1259.07 & 4.8094 & 31.402 & 6.512 \\
\hline 20 & 1096.75 & 1332.20 & 5.1418 & 30.192 & 6.909 \\
\hline 21 & 1129.40 & 1406.41 & 5.6667 & 29.198 & 7.309 \\
\hline 22 & 1175.69 & 1479.02 & 5.9806 & 28.118 & 7.730 \\
\hline 23 & 1198.75 & 1546.87 & 6.4910 & 26.822 & 8.108 \\
\hline 24 & 1231.72 & 1613.37 & 6.8557 & 25.792 & 8.508 \\
\hline 25 & 1250.47 & 1681.51 & 7.3701 & 24.365 & 8.908 \\
\hline 26 & 1291.77 & 1743.02 & 7.5710 & 23.214 & 9.311 \\
\hline 27 & 1322.93 & 1807.13 & 7.8847 & 22.092 & 9.707 \\
\hline 28 & 1335.63 & 1869.39 & 8.3400 & 21.036 & 10.107 \\
\hline 29 & 1344.44 & 1927.58 & 8.7790 & 19.808 & 10.506 \\
\hline 30 & 1353.94 & 1984.58 & 9.1879 & 18.855 & 10.908 \\
\hline 31 & 1375.00 & 2039.54 & 9.4697 & 18.038 & 11.308 \\
\hline 32 & 1380.96 & 2095.58 & 9.8737 & 17.166 & 11.707 \\
\hline 33 & 1394.53 & 2147.78 & 10.1758 & 16.205 & 12.107 \\
\hline
\end{tabular}


Table A-26. Deformation J/C and J-R curve results for specimen PWER-01

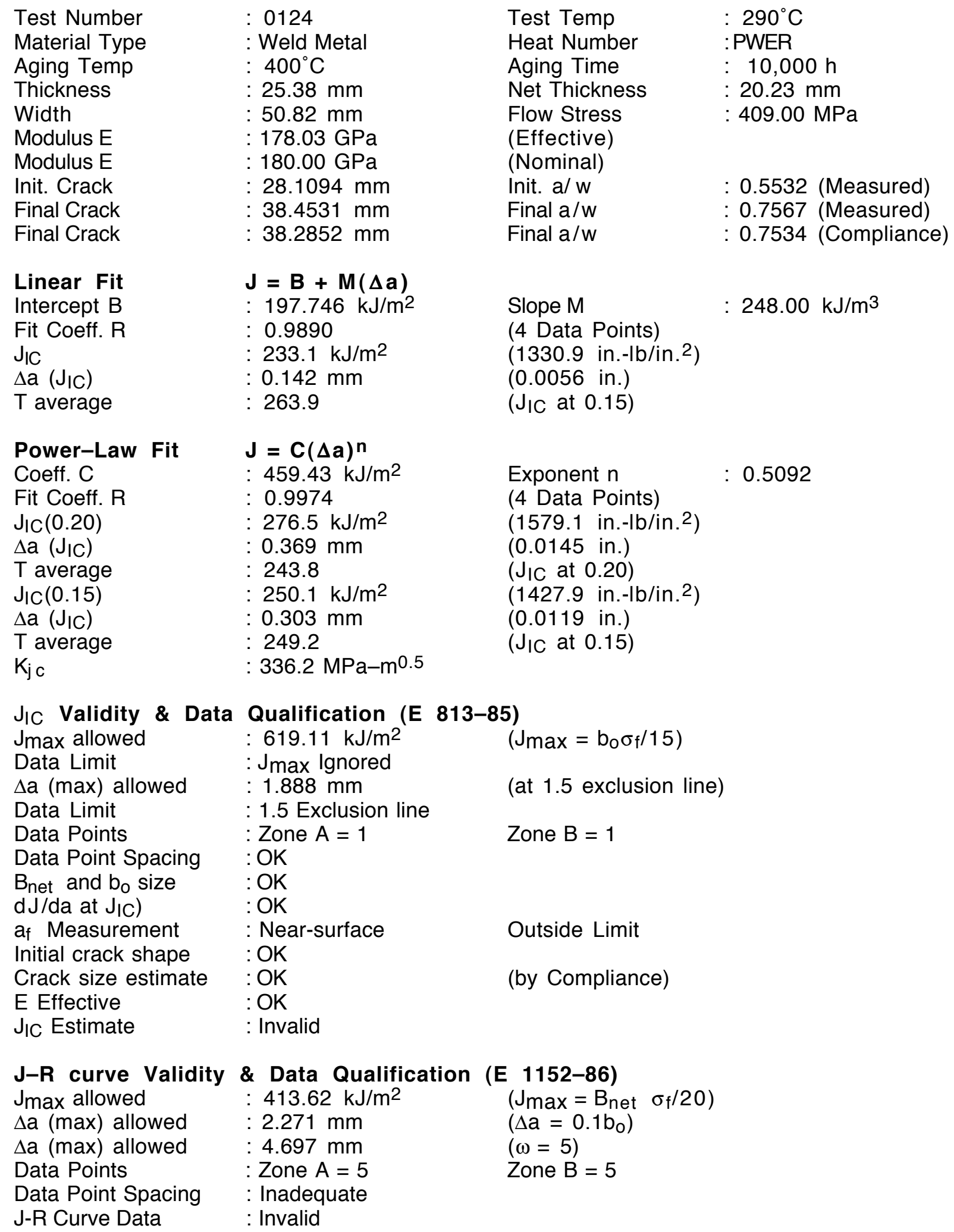


Table A-27. Modified JIC and J-R curve results for specimen PWER-01

\begin{tabular}{|c|c|c|c|}
\hline $\begin{array}{l}\text { Linear Fit } \\
\text { Intercept B } \\
\text { Fit Coeff. R } \\
\mathrm{J}_{\mathrm{IC}} \\
\Delta \mathrm{a}\left(\mathrm{J}_{\mathrm{IC}}\right) \\
\mathrm{T} \text { average }\end{array}$ & $\begin{array}{l}\mathbf{J}=\mathbf{B}+\mathbf{M}(\mathbf{\Delta} \mathbf{a}) \\
: 190.581 \mathrm{~kJ} / \mathrm{m}^{2} \\
: 0.9922 \\
: 229.2 \mathrm{~kJ} / \mathrm{m}^{2} \\
: 0.140 \mathrm{~mm} \\
: 293.3\end{array}$ & $\begin{array}{l}\text { Slope M } \\
\text { (4 Data Points) } \\
\left(1308.7 \text { in.-lb/in. }{ }^{2}\right) \\
(0.0055 \text { in. }) \\
\left(J_{I C} \text { at } 0.15\right)\end{array}$ & $275.59 \mathrm{~kJ} / \mathrm{m}^{3}$ \\
\hline $\begin{array}{l}\text { Power-Law Fit } \\
\text { Coeff. C } \\
\text { Fit Coeff. } \mathrm{R} \\
\mathrm{J}_{\mathrm{IC}}(0.20) \\
\Delta \mathrm{a}\left(\mathrm{J}_{\mathrm{IC}}\right) \\
\mathrm{T} \text { average } \\
\mathrm{J}_{\mathrm{IC}}(0.15) \\
\Delta \mathrm{a}\left(\mathrm{J}_{\mathrm{IC}}\right) \\
\mathrm{T} \text { average } \\
\mathrm{K}_{\mathrm{j}} \mathrm{C}\end{array}$ & $\begin{array}{l}\mathbf{J}=\mathbf{C}(\Delta \mathbf{a}) \mathbf{n} \\
: 480.32 \mathrm{~kJ} / \mathrm{m}^{2} \\
: 0.9979 \\
: 281.3 \mathrm{~kJ} / \mathrm{m}^{2} \\
: 0.372 \mathrm{~mm} \\
: 269.2 \\
: 252.4 \mathrm{~kJ} / \mathrm{m}^{2} \\
: 0.304 \mathrm{~mm} \\
: 274.8 \\
: 348.7 \mathrm{MPa}-\mathrm{m}^{0.5}\end{array}$ & $\begin{array}{l}\text { Exponent } n \\
(4 \text { Data Points) } \\
\left(1606.4 \text { in.-lb/in. }{ }^{2}\right) \\
(0.0146 \text { in.) } \\
\left(\mathrm{J}_{\mid C} \text { at } 0.20\right) \\
\left(1441.0 \text { in.-lb/in. }{ }^{2}\right) \\
(0.0120 \text { in.) } \\
\left(J_{I C} \text { at } 0.15\right)\end{array}$ & 0.5409 \\
\hline
\end{tabular}

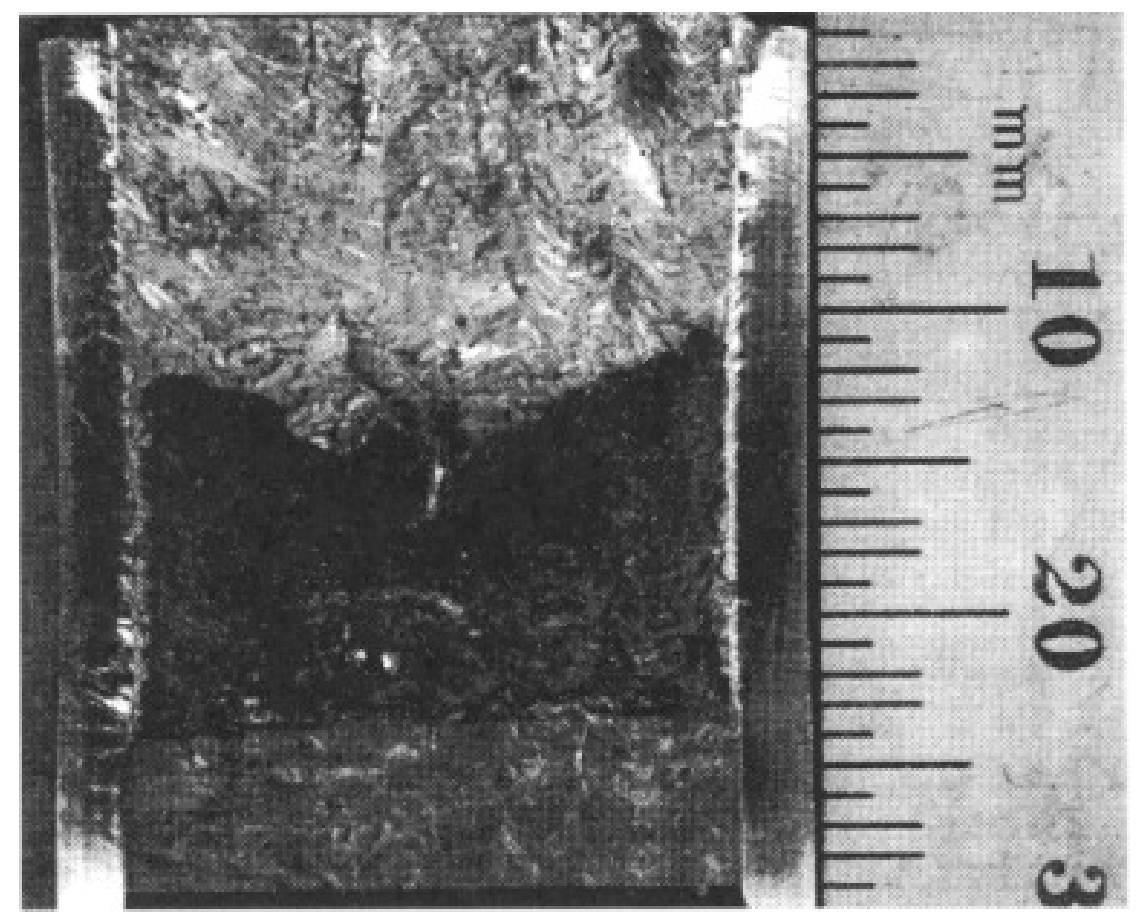

Figure A-25. Fracture surface of aged weld metal PWER tested at $290^{\circ} \mathrm{C}$ 


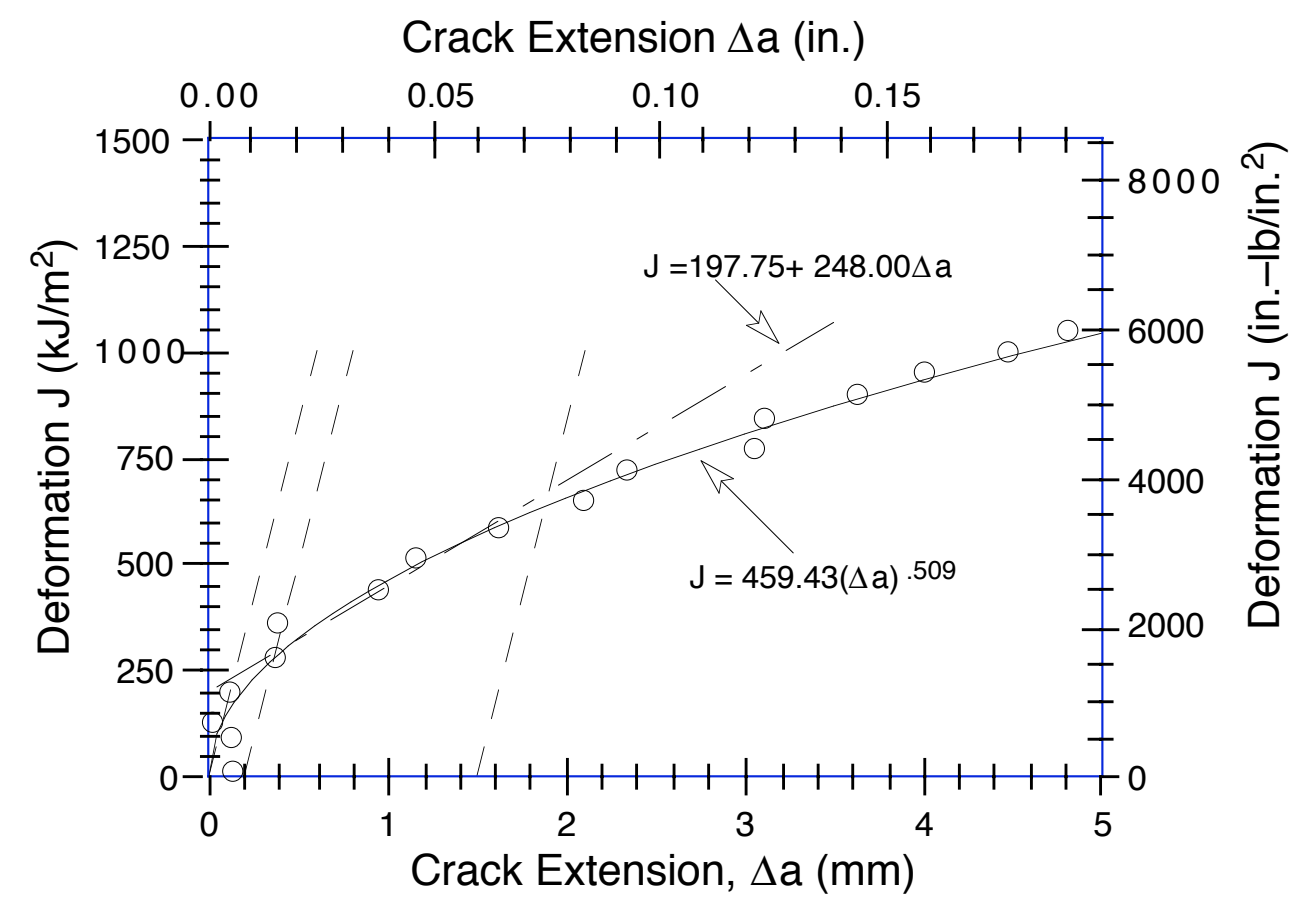

Figure A-26. Deformation J-R curve for weld metal specimen PWER-01 aged at $400^{\circ} \mathrm{C}$ for $10,000 \mathrm{~h}$ and tested at $290^{\circ} \mathrm{C}$. Blunting, 0.2- $\mathrm{mm}$ offset, and 1.5- $\mathrm{mm}$ offset lines are shown as dashed lines.

Crack Extension $\Delta \mathrm{a}$ (in.)

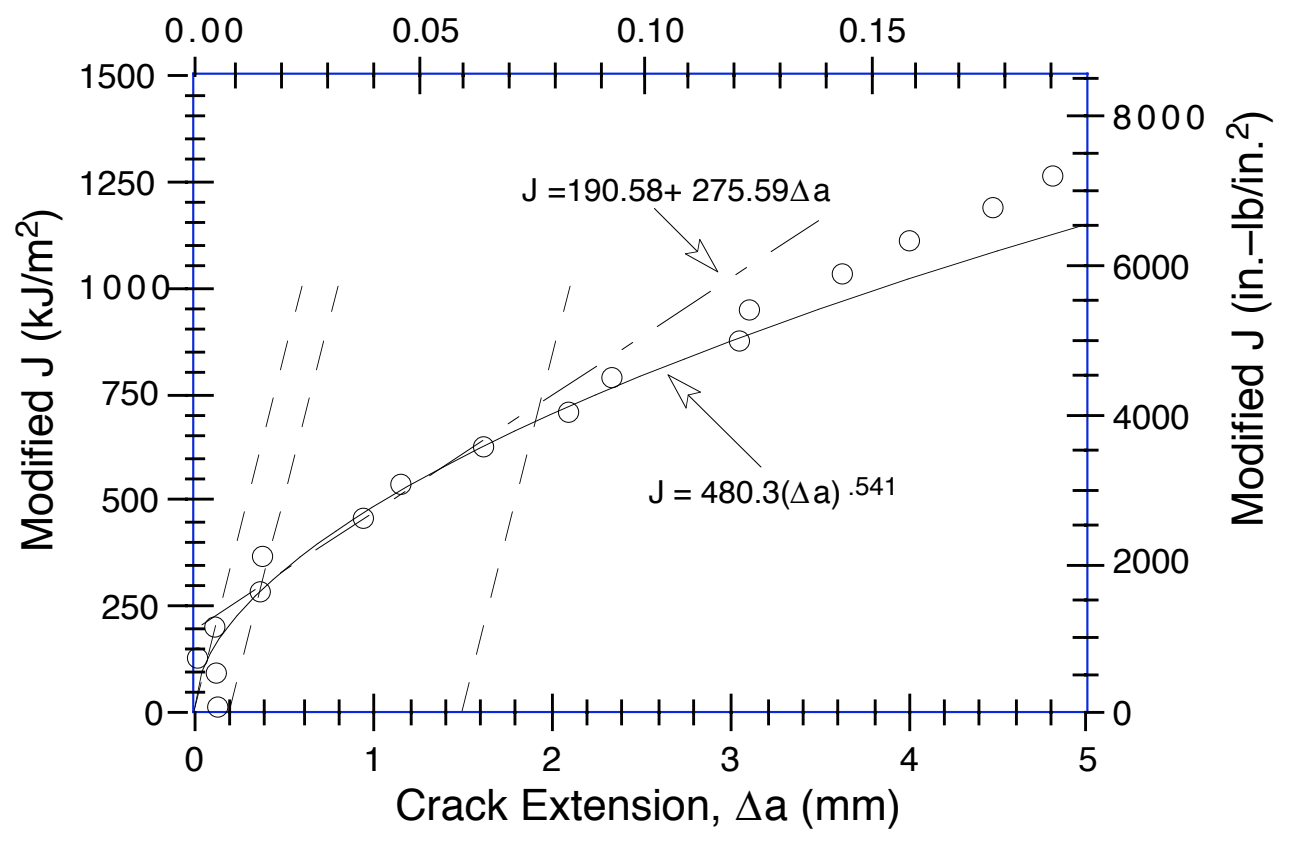

Figure A-27. Modified J-R curve for metal specimen PWER-01 aged at $400^{\circ} \mathrm{C}$ for $10,000 \mathrm{~h}$ and tested at $290^{\circ} \mathrm{C}$. Blunting, 0.2- $\mathrm{mm}$ offset, and 1.5-mm offset lines are shown as dashed lines. 
Internal:

W. F. Burke

O. K. Chopra (20)

T. M. Galvin

D. J. Gavenda (5)
T. F. Kassner

C. Malefyt

W. F. Michaud

R. B. Poeppel
W. J. Shack

C. E. Till

R. W. Weeks

TIS Files

External:

NRC, for distribution per R5

ANL Libraries

ANL-E (2)

ANL-W

Manager, Chicago Field Office, DOE

Energy Technology Division Review Committee

H. K. Birnbaum, University of Illinois, Urbana

R. C. Buchanan, University of Cincinnati, Cincinnati, $\mathrm{OH}$

S.-N. Liu, Fremont, CA

H. S. Rosenbaum, Fremont, CA

R. K. Shah, University of Kentucky, Lexington

S. Smialowska, Ohio State University, Columbus

R. E. Smith, Altran Corp., Huntersville, NC

D. Atteridge, Battelle Pacific Northwest Laboratory

W. H. Bamford, Westinghouse Electric Corp., Pittsburgh, PA

K. K. Bandyopadhyay, Brookhaven National Laboratory

J. A. Christensen, Battelle Pacific Northwest Laboratory

A. Cowan, Risley Nuclear Power Development Labs., Risley, Warrington, UK

W. H. Cullen, Materials Engineering Associates, Inc., Lanham, MD

B. J. L. Darlaston, Berkeley Nuclear Laboratories, Berkeley, Gloucestershire, UK

G. Gage, AEA Technology, Harwell Laboratory, Oxfordshire, UK

J. Gilman, Electric Power Research Inst., Palo Alto, CA

W. Gysel, Georg Fischer, Ltd., Schaffhausen, Switzerland

G. E. Hale, The Welding Institute, Abington, Cambridge, UK

P. Hedgecock, APTECH Engineering Services, Inc., Palo Alto, CA

B. Hemsworth, HM Nuclear Installations Inspectorate, London, UK

C. Hoffmann, ABB CE Nuclear Power, Windsor, CT

J. Jansky, Büro für Technische Beratung, Leonberg, Germany

C. E. Jaske, CC Technologies, Cortest, Columbus, OH

G. J. Licina, Structural Integrity Associates, San Jose, CA

T. R. Mager, Westinghouse Electric Corp., Pittsburgh, PA

H. Mehta, General Electric Co., San Jose, CA

Y. Meyzaud, Framatome, Paris La Defense, France

M. Prager, Materials Properties Council, Inc., New York, NY

D. Quiñones, Robert Cloud \& Associates, Berkeley, CA

C. Y. Rieg, Electricité de France, Villeurbanne Cedex, France

V. N. Shah, EG\&G Idaho, Inc., Idaho Falls, Idaho 
G. Slama, Framatome, Paris La Defense, France

D. M. Stevens, Lynchburg Research Center, Babcock \& Wilcox Co., Lynchburg, VA

L. Taylor, Nuclear Electric plc., Chelsford Rd., Knutsford, Cheshire, UK

J. C. Van Duysen, Electricité de France, Moret-Sur-Loing, France

S. Yukawa, Boulder, CO 
NRC FORM 335

(2-89)

NRCM 1102

3201, 3202
BIBLIOGRAPHIC DATA SHEET

(See instructions on the reverse)

U. S. NUCLEAR REGULATORY COMMISSION 1. REPORT NUMBER

(Assigned by NRC. Add Vol., Supp., Rev., and Addendum Numbers, if any.)

NUREG/CR-6428

ANL-95/47

2. TITLE AND SUBTITLE

Effects of Thermal Aging on Fracture Toughness and Charpy-Impact Strength of

Stainless Steel Pipe Welds

\section{AUTHOR(S)}

D. J. Gavenda, W. F. Michaud, T. M. Galvin, W. F. Burke, and O. K. Chopra

8. PERFORMING ORGANIZATION - NAME AND ADDRESS (If NRC, provide Division, Office or Region, U.S. Nuclear Regulatory Commission, and mailing address; if contractor, provide name and mailing address.)

Argonne National Laboratory

9700 South Cass Avenue

Argonne, IL 60439

9. SPONSORING ORGANIZATION - NAME AND ADDRESS (If NRC, type "Same as above": if contractor, provide NRC Division, Office or Region, U.S. Nuclear Regulatory Commission, and mailing address.)

Division of Engineering

Office of Nuclear Regulatory Research

U.S. Nuclear Regulatory Commission

Washington, DC 20555

10. SUPPLEMENTARY NOTES

11. ABSTRACT (200 words or less)

The degradation of fracture toughness, tensile, and Charpy-impact properties of Type 308 stainless steel (SS) pipe welds due to thermal aging has been characterized at room temperature and $290^{\circ} \mathrm{C}$. Thermal aging of SS welds results in moderate decreases in Charpy-impact strength and fracture toughness. For the various welds in this study, upper-shelf energy decreased by $50-80 \mathrm{~J} / \mathrm{cm}^{2}$. The decrease in fracture toughness $\mathrm{J}-\mathrm{R}$ curve or $\mathrm{J} \mathrm{C}$ is relatively small. Thermal aging had little or no effect on the tensile strength of the welds. Fracture properties of SS welds are controlled by the distribution and morphology of second-phase particles. Failure occurs by the formation and growth of microvoids near hard inclusions. Such processes are relatively insensitive to thermal aging. The ferrite phase has little or no effect on the fracture properties of the welds. Differences in fracture resistance of the welds arise from differences in the density and size of inclusions. The mechanical-property data from the present study are consistent with results from other investigations. The existing data have been used to establish minimum expected fracture properties for SS welds.

12. KEY WORDS/DESCRIPTORS (List words or phrases that will assist researchers in locating this report.)

\begin{tabular}{|c|}
\hline $\begin{array}{l}\text { 13. AVAILABILITY STATEMENT } \\
\text { Unlimited }\end{array}$ \\
\hline 14. SECURITY CLASSIFICATION \\
\hline (This Page) \\
\hline Unclassified \\
\hline (This Report) \\
\hline Unclassified \\
\hline 15. NUMBER OF PAGES \\
\hline 16. PRICE \\
\hline
\end{tabular}

